University of Rhode Island

DigitalCommons@URI

Open Access Master's Theses

1981

\title{
A REVITALIZATION STUDY OF MERRIMAC SQUARE - MERRIMAC, MASSACHUSETTS
}

Diane Lee Flint

University of Rhode Island

Follow this and additional works at: https://digitalcommons.uri.edu/theses

\section{Recommended Citation}

Flint, Diane Lee, "A REVITALIZATION STUDY OF MERRIMAC SQUARE - MERRIMAC, MASSACHUSETTS" (1981). Open Access Master's Theses. Paper 482.

https://digitalcommons.uri.edu/theses/482

This Thesis is brought to you for free and open access by DigitalCommons@URI. It has been accepted for inclusion in Open Access Master's Theses by an authorized administrator of DigitalCommons@URI. For more information, please contact digitalcommons-group@uri.edu. 


\section{A \\ Revitalization Study of \\ Merrimac Square}

Merrimac

Massachusetts

Fall 1981

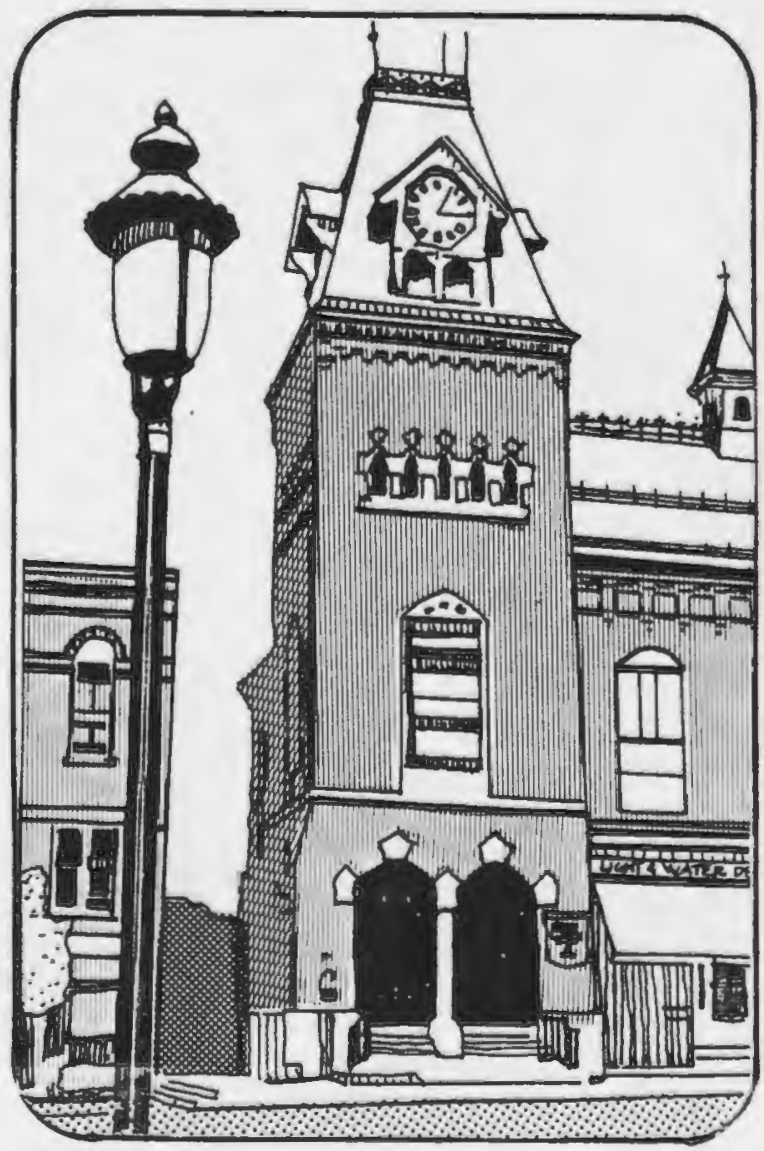




\section{A REVITALIZATION STUDY \\ OF \\ MERRIMAC SQUARE \\ MERRIMAC, MASSACHUSETTS}

A THESIS PROJECT SUBMITTED IN

PARTIAL FULFILLMENT OF THE REQUIREMENTS

FOR THE DEGREE OF

MASTER OF COMMUNITY PLANNING 


\author{
A REVITALIZATION STUDY \\ OF \\ MERRIMAC SQUARE \\ MERRIMAC, MASSACHUSETTS
}

\title{
MASTER OF COMUUNITY PLANNING \\ ... THESIS PROJECT \\ $\mathrm{OF}$ \\ DIANE LEE FLINT
}

APPROVED :

MAJOR PROFESSOR

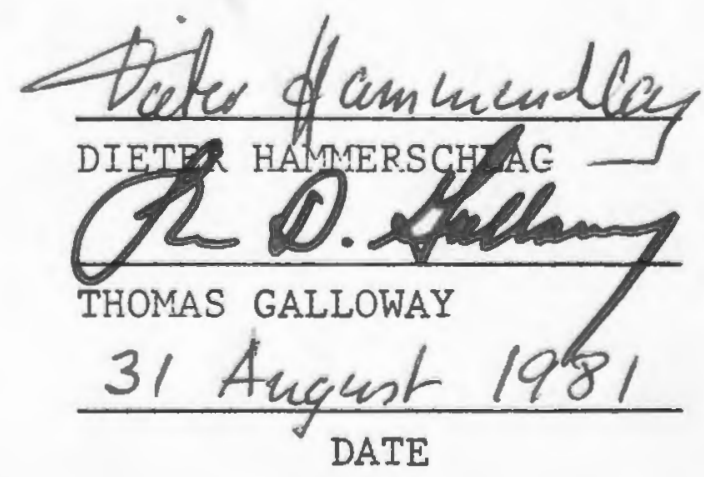


I. INTRODUCTION

II. GENERAL BACKGROUND 3

Location and Regional Setting 3

Commity Profile 9

Characteristics of the Population and Local Economy Community Development Concerns

$\begin{array}{ll}\text { III. INVENTORY AND NEEDS ASSESSMENT } & 16\end{array}$

$\begin{array}{ll}\text { Population Trends } & 16\end{array}$

$\begin{array}{ll}\text { Historic Preservation } & 17\end{array}$

Historical Perspective

Inventory

Historic Preservation Concerns

Physical Conditions

Building Appearance Survey

Infrastructure

Signs

Land Use and Zoning

Land Use

Zoning

Transportation

Traffic and Circulation Analysis

Parking

Public Transportation

Economic Analysis

An Assessment of Existing Conditions

Merchants Survey

Market Analysis 
Shoppers Survey

Loitering Problem

IV. GOALS AND RECOMMENDATIONS

Introduction $\quad 81$

Historic Preservation $\quad 83$

Physical $\quad 84$

Aesthetic $\quad 85$

Land Use Controls $\quad 87$

Circulation $\quad 89$

Parking $\quad 90$

Economic $\quad 92$

Social Concerns $\quad 92$

Housing $\quad 93$

V. IMPLEMENTATION 94

Introduction $\quad 94$

$\begin{array}{lr}\text { Organizational Structure } & 94\end{array}$

$\begin{array}{ll}\text { Merchants Group } & 96\end{array}$

Promotion 96

$\begin{array}{lr}\text { Private Entrepreneurs } & 97\end{array}$

$\begin{array}{ll}\text { Financing and Funding Sources } & 98\end{array}$

$\begin{array}{ll}\text { VI. CONCLUSION } & 102^{\circ}\end{array}$

$\begin{array}{ll}\text { FOOTNOTES } & 104\end{array}$

$\begin{array}{ll}\text { BIBLIOGRAPHY } & 108\end{array}$

$\begin{array}{ll}\text { APPENDICES } & 111\end{array}$ 


\section{LIST OF MAPS}

Page

1. Regional Setting of Merrimac 4

2. Location of Merrimac Square 5

3. Study Area Boundary Map 7

4. Survey of Historic Resources 21

5. Building Appearance Survey 32

6. Land Use in Merrimac Square 38

7. Zoning Map, Town of Merrimac 40

8. Zoning Classifications in Merrimac Square

9. Transportation 44

10. Vacant and Underutilized Floor Area in Merrimac Square

11. Merrimac's Trade Area

12. Physical Improvements for Merrimac Square

13. Summary of Recommendations 


\section{LIST OF TABIES}

$\underline{\text { Table }}$

Page

1. Property Tax Valuations - Town of Merrimac, 1981

11

2. The Econony of Merrimac, Massachusetts - The Number of Firms by Sector, 1971-1979

3. The Economy of Merrimac, Massachusetts - Employment by Sector, 1971-1979

4. Population Growth: 1930-1980, Town of Merrimac and Merrimack Valley Planning Commission Region (MVPC)

5. Population Projections - Town of Merrimac, 1980-1995

6. Structures of Historic and Architectural Significance 20

7. Building Appearance

8. Land Use by Type - Merrimac Square

9. Peak Hour Parking - Demand Versus Supply: Merrimac Square

10. Merrimac Square - Occupancy of Building, Floor Area

11. Retail Sales Per Capita - Lawrence/Haverhill SMSA 1977

12. Estimation of Retail Sales Per Capita - Population, Town of Merrimac, 1977

13. Projection of Retail Sales Per Capita - Town of Merri- 65 mac, 1980-1995

14. Projected Retail Sales - Town of Merrimac, 1980-1995 66

15. National Median Annual Sales Volume Per Square Foot 66 of Gross Leasable Floor Area, 1975

16. Future Demand for Convenience Retail Space, 1980-1995 67

17. Future Demand for Office Space - Town of Merrimac, 68 1980-1995

18. Police Calls Involving Merrimac Square, June 1981 
ACKNOWLEDGEMENTS

I would like to gratefully acknowledge the many people whose invaluable assistance, insights and support contributed to the preparation of this report.

First and foremost, I would like to thank Dieter Hammerschlag, my major professor, for his encouragement, sincere interest, advice, constructive criticisms and timely editorial review of this report.

I am most grateful to the local officials, merchants and townspeople of Merrimac for providing background information and sharing their ideas and concerns with me. I would especially like to thank Nancy MacGregor, Selectwoman; Arthur Evans, Planning Board; Nancy Perkins, Merrimac Beautification Committee; Mary Marsh, Council on Aging; Jeffrey Hoyt, Merrimac Historical Commission; Police Chief, Donald J. Montigny and Sergeant Alfred Nichols, Merrimac Police Department; Ray Bastarache, Water Department; and the employees at the Town Hall. I hope the results of this study will be as valuable to the people of Merrimac as their time and assistance was to me.

I would also like to thank the Merrimack Valley Planning Commission for supporting this effort and granting the use of their facilities. I would like to especially acknowledge David Koven for his technical advice throughout the project and Vail Pagliarani for the preparation of the base map. Special thanks are extended to Valerie Sawyer for the time and effort put into the final editing and typing of this report 
and to Maureen Brady for her assistance with the survey. Also, I would like to recognize Edward Pearson for his most generous contribution of the aerial photographs found in the report. And finally, I would like to acknowledge those close to me whose faith in me and unending words of encouragement served as a source of inspiration and guided me through the completion of this project and the graduate program of community planning. To my parents and Gary, I express deep appreciation, for their love, interest and constant support. 


\section{INTRODUCTION}

The Town of Merrimac is located approximately 35 miles north of Boston on the New Hampshire border. Merrimac developed as a small industrial town and became prosperous during the latter part of the nineteenth century, as a center for the manufacture of horsedrawn carriages.

Merrimac Square, the area selected for study, was the focus of activity during these years. Established on the Square were carriage finding houses, the carriage shops themselves, an elegant town hall building donated by a well-to-do native and many fine homes of the carriage business entrepreneurs. Today, many of these structures remain, strongly reinforcing Merrimac's historic heritage and providing charm and character to the area.

While the carriage industry waned near the turn of the century, with the advent of the automobile, the Square continued to be the institutional and commercial center of Merrimac well into the first half of the twentieth century. During the fifties and sixties however, Merrimac Square merchants began to experience economic difficulties resulting from increased competition with suburban shopping centers in surrounding communities. Consequently, downtown Merrimac started to decline--a fate not uncommon to older central business districts.

Today, obvious signs of decline are present, evidenced by the deterioration of buildings, vacant storefronts, underutilized space, and a fairly rapid rate of business turnover.

Some efforts have been made in the past ten years, by enthusiastic civic, volunteer groups and merchants, to improve the 
conditions of Merrimac Square. A new comprehensive and bold revitalization strategy involving both the private and public sector is necessary however, to reverse persistent downward trends and stabilize the area, as the viability of the Square is essential to the overall economy and well-being of the town. It is hoped that this report will be the first step in that renewal process.

The overall purpose of this report is to assess the physical and economic conditions of the Square and develop specific strategies for directing future revitalization efforts. Chapter Two provides background information and a community profile to set the framework for viewing the problems of the Square. Chapter Three includes a comprehensive analysis of population trends, historic resources, physical conditions, land use, zoning, traffic circulation, parking, economic and market potential; social concerns and consumer attitudes. Specific goals and recommendations (accompanied by sketches and maps) for addressing these issues are provided in Chapter Four. Finally, Chapter Five includes strategies for implementing recommendations, as well as information on available funding and financing mechanisms. The information and data contained in this report should be used as a resource by the town, for future planning activities as well as a basis for federal grants-in-aid.

While this study is only the beginning of Merrimac Square's revitalization process - an assessment of what is, with recommendations for what could be - it is hoped that this report will broaden the awareness of the townspeople and stimulate interest in meeting the challenges that lie ahead. 
II. GENERAL BACKGROUND

Location and Regional Setting

The Town of Merrimac, Massachusetts is located approximately 35 miles north of Boston in Essex County on the New Hampshire border. Merrimac, which is part of the Merrimack Valley Planning Region, is situated midway between Newburyport and Lawrence. Amesbury borders the town to the east and Haverhill lies to the west. The Merrimack River forms the southerly border of the town and the rural community of Newton, New Hampshire is at the north. Route 495, the outer beltway around the Boston Metropolitan area, bisects the Town of Merrimac and provides excellent transportation linkages with major regional cities and U. S. Interstate 95 (see Map 1).

Merrimac Square is the central business district of the commity. It is conveniently and centrally located at the intersection of State Route 110, which was once the only major east-west thoroughfare between Haverhill and Amesbury, and Church and School Streets (see Map 2).

The area selected for study generally includes in an eastwest direction, land between the Sawyer House and Iittle Court, and, in a north-south direction, the Congregational Church and Senior Center (see Map 3). These boundaries were designed to encompass the existing commercial area, and major institutional and historic landmarks which contribute to the overall character of the Square. Key parcels which hold potential for future comercial development are also incorporated in the study area. 
MAP I REGIONAL SETTING OF MERRIMAC

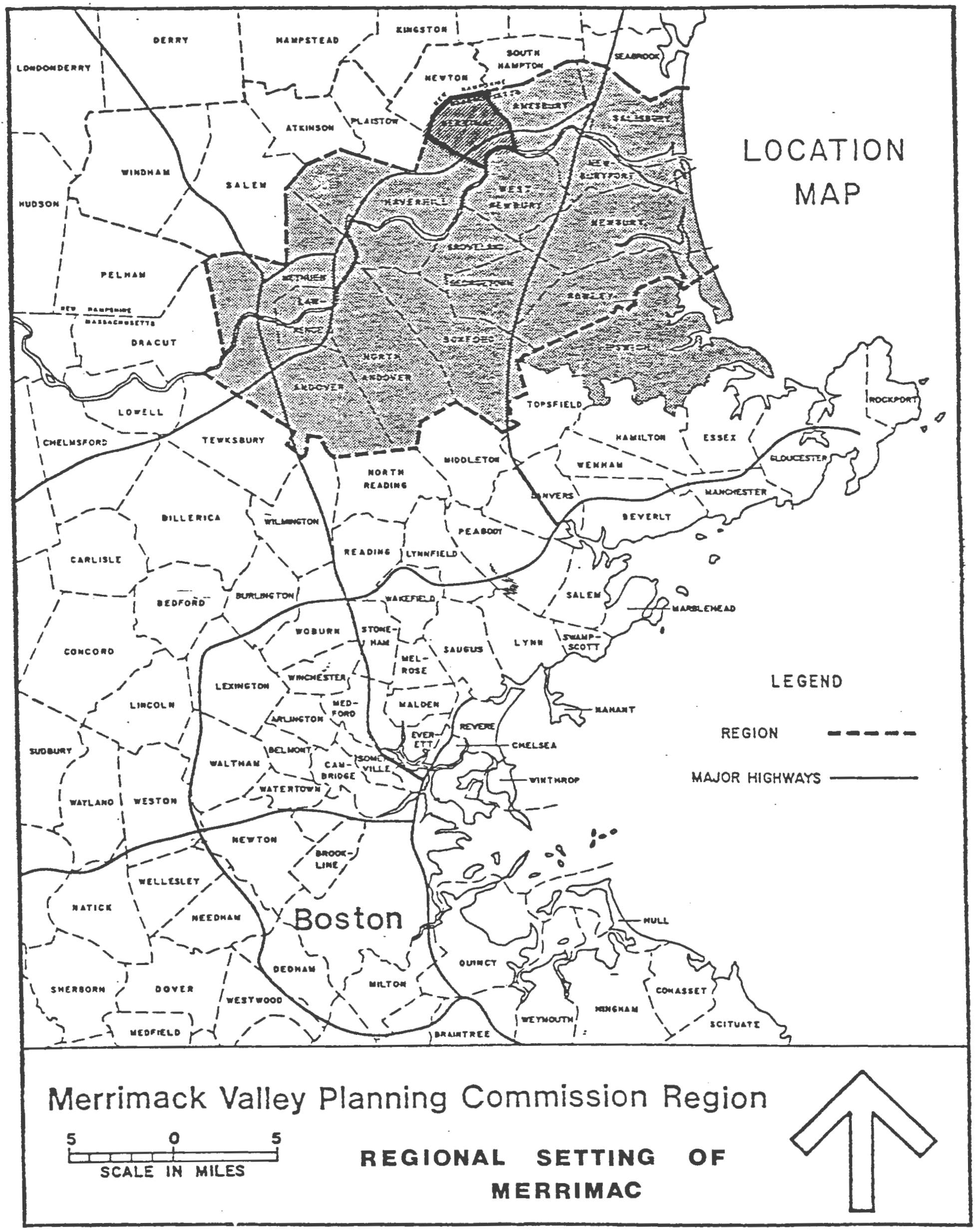


Merrimac
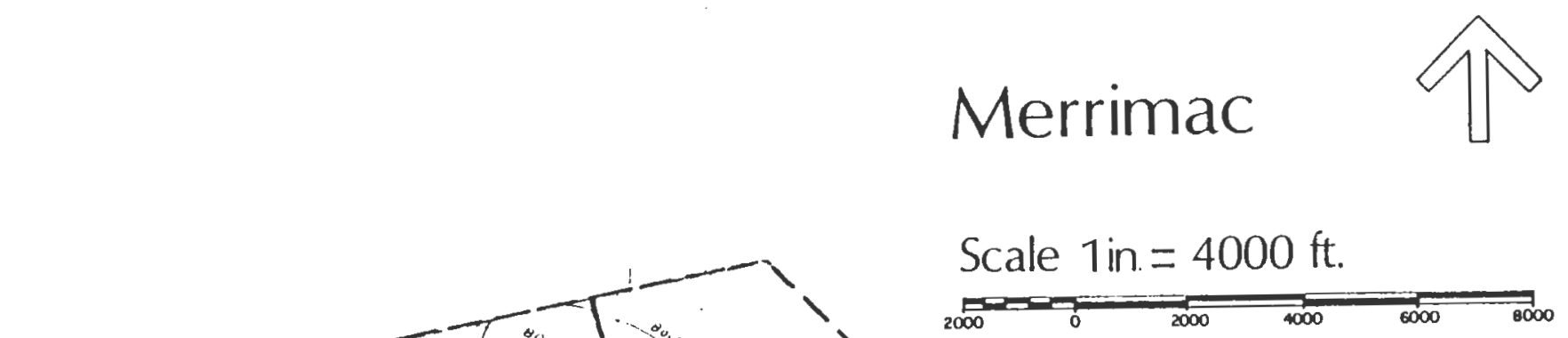


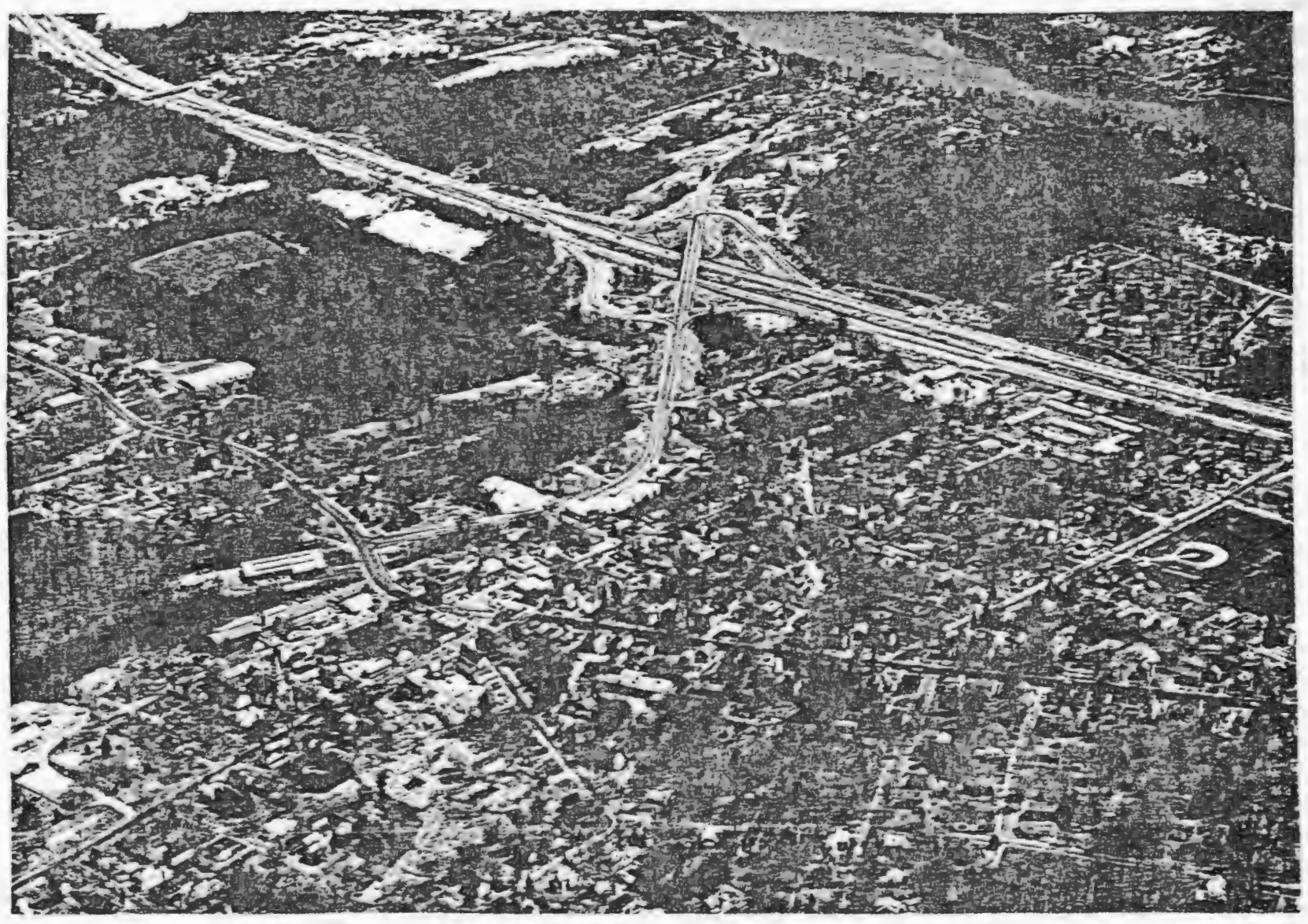

Merrimac, Massachusetts.

The Location of Merrimac Square in relation to the Merrimac River and U. S. Interstate Route 495 (looking southeast). 


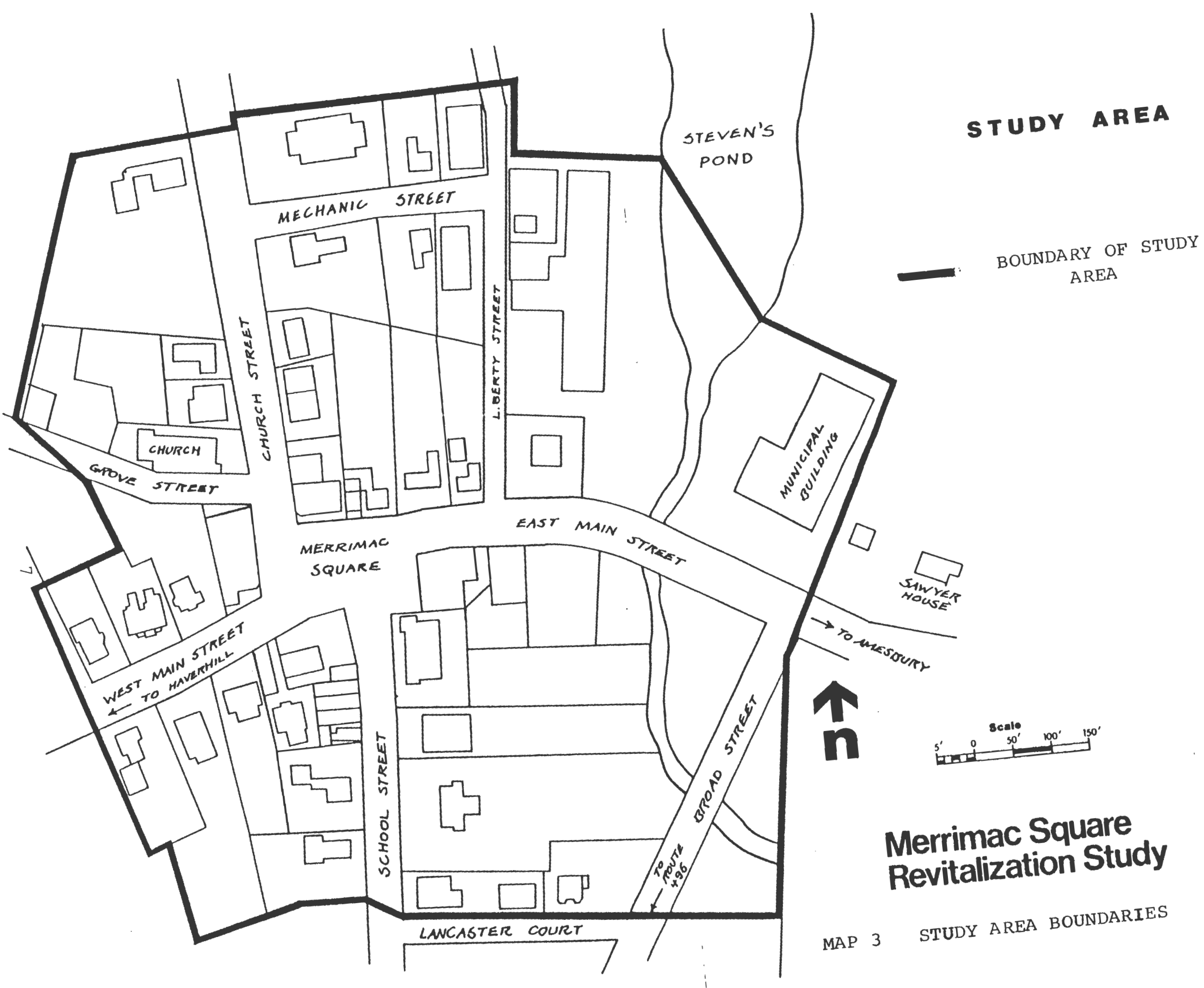



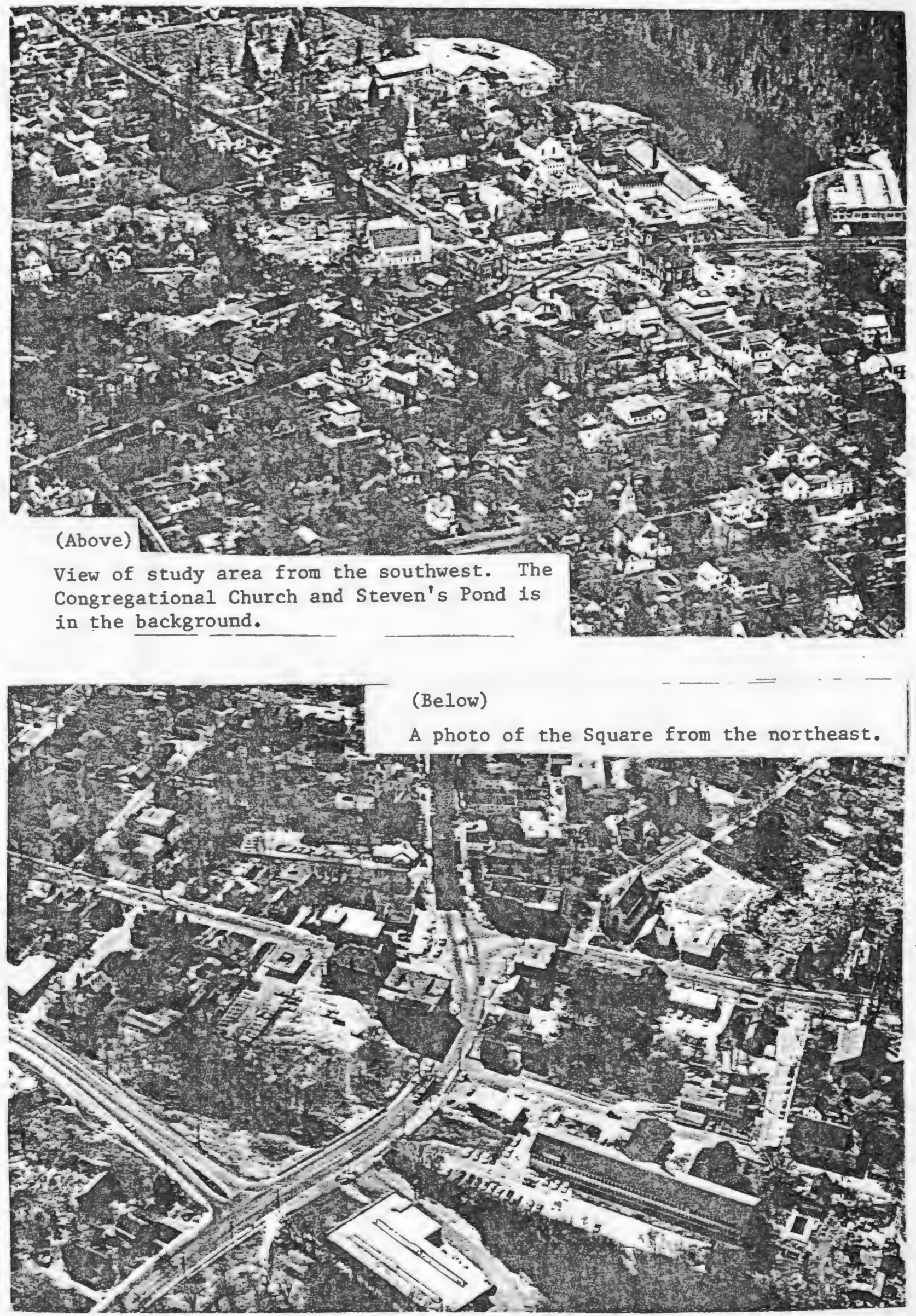
These boundaries were designed to closely conform to the existing commercial zoning district and the Town Center zone as proposed in the Master Plan ${ }^{1}$.

\section{Community Profile}

The purpose of the Community Profile is to briefly acquaint the reader with the social, economic and population characteristics of the Town of Merrimac, in order to provide a framework for analyzing the specific problems of Merrimac Square. Since sound "comprehensive planning" involves consideration of all interrelated intricacies of a community, the problems of the Square should not be viewed in isolation from broader concerns. In addition to improving understanding of Merrimac, this section will define some of the community development problems of the town and assess its future needs.

Characteristics of the Population and Local Economy

Merrimac is largely a white, lower-middle income working class community. The most recent available source of socioeconomic data is the 1970 Census. While somewhat dated, it provides an overview of the community ${ }^{2}$.

In 1970, only eight minorities were recorded as living in Merrimac, amounting to less than one percent of the population. While the ethnic backgrounds of the population varied, the largest groups were of Canadian, United Kingdom, and Irish origin.

The 1970 Census shows that 46 percent of the population was younger than age twenty-four and only ten percent of the population was of retirement age. Today, the town's age 
structure has changed. There has been a decrease in the number of school-aged children, evidenced by declining school enrollments ${ }^{3}$. The Merrimac Council on Aging has indicated that the elderly population has expanded in the past ten years, to comprise 18 percent of the town's total population ${ }^{4}$.

A total of 50 percent of the town's work force is employed in blue collar occupations. Only 19.5 percent are employed in white collar jobs, a percentage considerably lower than comparable regional figures ${ }^{5}$. The educational level of the community is slightly lower than the county average $^{6}$. The 1970 median family income estimate for Merrimac was $\$ 9,726$, significantly lower than the median income of $\$ 10,382$ recorded for the Lawrence-Haverhill SMSA ${ }^{7}$. It is estimated that 41 percent of the families in Merrimac are of low and moderate income, with 7.7 percent living below the poverty level ${ }^{8}$. Merrimac also has the third lowest per capita income in the Merrimack Valley Planning Region ${ }^{9}$.

High unemploynent is also a major problem in Merrimac. The town has, for the previous two calendar years, been designated a "Labor Surplus Area" by the Department of Labor. During this period, the town's unemployment rate was twenty percent above the national average ${ }^{10}$. Preliminary estimates for 1981: show Merrimac's unemployment rate at 7.9 percent, a figure significantly higher than the Region's unemployment rate of 4.9 percent and the State's unemployment rate of 5.2 percent $^{11}$. 
Merrimac is largely a bedroom community, as reflected in an analysis of the town's tax base. Table 1 shows a Table 1. PROPERTY TAY VALUATIONS - TOWN OF MERRIMAC,

\begin{tabular}{|c|c|c|}
\hline & VALUATION & PERCENTAGE \\
\hline Residential & $\$ 48,573,080$ & 85.24 \\
\hline Open Space & $2,552,425$ & 4.48 \\
\hline Cormercial & $3,960,170$ & 6.94 \\
\hline Industrial & $1,341,910$ & 2.35 \\
\hline Personal Property & 562,200 & .99 \\
\hline Total & $\$ 56,989,785$ & 100.00 \\
\hline
\end{tabular}

Source: Town of Merrimac Assessor's Records, 1981

tabulation of the town's tax base by land use classification. The majority of the town's tax base ( 85 percent) is derived from residential property valuations. Commercial and industrial properties contribute only 10 percent of the town's total taxable property value. A review of trends over time shows that while Merrimac's overall tax base has increased at a rate of two to three percent annually, commercial valuations have declined ${ }^{12}$. Such trends indicate that an increasing tax burden is being placed on residential property owners in order to provide for necessary municipal services.

A number of firms are located within the town which provide local employment opportunities (see Table 2). Employment is broken down by economic sector in Table 3 and compared over time. 
Table 2. THE ECONOMY OF MERRIMAC, MASSACHUSETTS, THE NUMBER OF FIRMS BY SECTOR, 1971 AND 1979

INDUSTRIES

1. Agriculture

2. Construction

3. Manufacturing

4. Transportation, Communications, Utilities

5. Wholesale and Retail Trade

6. Finance, Insurance and Real Estate

7. Service Industry

\section{$1971 \quad \underline{1979} \quad \underline{1971-1979}$ \\ CHANGE}

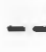

10

14

$+4$

12

2

19

3

9

$-$

14

8

$-4$

5

$+3$

21

$+2$

4

$+1$

$-2$

Source: Massachusetts Division of Employment Security Employment and Payroll, 1971 and 1979; Town of Merrimac.

Table 3. THE ECONOMY OF MERRIMAC, MASSACHUSETTS, EMPLOYMENT BY SECTOR, 1971 and 1979

\section{INDUSTRIES}

1. Agriculture

2. Construction

3. Manufacturing

4. Transportation, Communications, Utilities

5. Wholesale and Retail Trade

6. Finance, Insurance 14 and Real Estate

7. Service

192

2

$$
1971
$$

Percent Change$$
\text { Em. } 1971 \text { of Total }
$$

\section{--}

33

139

18

8.0

$+50.0$

56.0

35.0

5.0

$-28.0$

0.5

27.0

100

25.0

$+91.0$

19

5.0

$+36.0$ 84

21.0 $+265.0$ 393

$+13.5$

Source: Massachusetts Division of Employment Security - Employment and Payro11, 1971 and 1979; Town of Merrimac. 
Table 3 shows that employment overall has increased by 13.5 percent since 1971. All sectors of the local economy have grown except manufacturing. However, manufacturing still remains the largest sector of the economy, providing 35 percent of all employment opportunities in the town. The recently announced move of Wolverine Industries from Lawrence to Merrimac is forecast to provide an additional 200-300 local manufacturing jobs, and will help to revive the town's declining manufacturing sector. ${ }^{13}$.

It should be noted that services and wholesale/retail trade have been the fastest growing sectors of Merrimac's economy. This is clearly a positive sign in terms of the revitalization of Merrimac Square. Community Development Concerns

In light of Merrimac's high percentage of low and moderate income residents and persistently high unemployment rates, the town is eligible for a variety of federal funding sources, including Community Development Block Grants (CDBG) and Urban Development Action Grants (UDAG). These programs serve to aid economically depressed areas and improve living conditions among the disadvantaged. A major thrust of these programs, and an area of primary concern in Merrimac, is the provision of adequate housing for low and moderate income families.

In August, 1979, it was estimated that 321 households in Merrimac were in need of housing assistance ${ }^{14}$. This need is due, in part, to a local shortage of subsidized housing units, lack of affordable private housing opportunities 
and a high level of substandard housing conditions.

To date, there are only 66 subsidized units available in Merrimac. The majority of these units are for the elderly ${ }^{15}$. There has been little apartment construction in the town over the past ten years, despite an increasing regional demand for multi-family housing. In total, there are fewer than 100 units of multi-family housing in Merrimac ${ }^{16}$. Rents vary between $\$ 250-300$ per month ${ }^{17}$. For many low and moderate income families, market rents exceed 25 percent of income guidelines.

Housing problems in Merrimac are further aggravated by the deteriorated condition of existing housing. Analysis of 1970 Housing Census data and a more recent 1976 survey indicates that 395 units, roughly 30 percent of the town's housing stock, is substandard ${ }^{18}$. The majority of these units are located in the densely populated sections of the town, in close proximity to Merrimac Square. In response to this problem, the town applied for and received funding in 1977 under the Small Cities Community Development Block Grant Program to upgrade substandard properties.

To date, 72 units have been rehabilitated through a Housing Rehabilitation Incentive Grant Program ${ }^{19}$.

While these local initiatives have somewhat eased the housing problem, there is still a significant number of families in Merrimac who are in need of housing assistance. Housing, therefore, remains an area of considerable need. 
This chapter has provided an overview of the social and economic climate of the Town of Merrimac. Merrimac is a white, low to moderate income working class bedroom community. At present, the economic mainstay of the community is manufacturing. However, manufacturing trends in recent years show a persistent decline. Overall, economic conditions are poor, evidenced by a high unemployment rate, concentration of low and moderate income families, low per capita incomes, declining commercial tax base, deteriorated housing conditions, and other signs of a "distressed" community. These concerns deserve the attention of local officials and should be considered as part of the Merrimac Square Revitalization stragegy. 
III. INVENTORY AND NEEDS ASSESSMENT

Population Trends

An analysis of population trends shows that after experiencing a slight decline in population during the 1930's, the Town of Merrimac grew significantly in the post World War II years. This was in contrast to fairly slow growth occurring elsewhere in the region. Between 1940 and 1980, the population of Merrimac almost doubled in size. Table 4 compares population trends in Merrimac with the Merrimack Valley Planning Region.

Table 4. POPULATION GROWTH: 1930-1980, TOWN OF MERRIMAC AND MERRIMACK VALLEY PLANNING REGION

\begin{tabular}{|c|c|c|c|}
\hline $\begin{array}{r}- \\
\text { YEAR }\end{array}$ & $\begin{array}{c}\text { MERRIMAC } \\
\text { POPULATION } \\
\end{array}$ & $\begin{array}{l}\% \text { POPULA- } \\
\text { TION CHANGE } \\
\text { MERRIMAC } \\
\end{array}$ & $\begin{array}{c}\% \text { POPULATION } \\
\text { CHANGE MVPC } \\
\text { REGION } \\
\end{array}$ \\
\hline 1930 & $2,392^{-}$ & -- & $-\cdots$ \\
\hline 1940 & 2,320 & -3.0 & -1.0 \\
\hline 1950 & 2,804 & +20.8 & 2.0 \\
\hline 1960 & 3,261 & +16.2 & 2.9 \\
\hline 1970 & 4,245 & +23.2 & 2.9 \\
\hline 1980 & 4,451 . & +4.8 & $\cdots$ \\
\hline
\end{tabular}

Sources: MVPC Overall Economic Development Program, Merrimack . Valley Planning Commission, 1981.

City and Town Monograph, Town of Merrimac, Massachusetts Department of Commerce and Development, November, 1973.

1980 Census of Population and Housing, Massachusetts, Final Population and Housing Unit Counts, U. S. Department of Commerce Census Bureau, 1980.

Growth in Merrimac during the past decade has slowed considerably. After three decades of rapid growth, with rates in excess of 15 percent per decade, Merrimac's population grew by a moderate five percent between 1970 and 1980. Essex County, which contains 
the Town of Merrimac, experienced a seven percent decline in population during this same time period ${ }^{20}$.

Despite its slow growth in population, Merrimac's growth in terms of dwelling units is fairly significant. A total of 640 new housing units were constructed in the town between 1970 and 1980 - a 20 percent increase in dwelling units ${ }^{21}$. This increase was also greater than that experienced by Essex County, which showed a 13 percent increase in housing units during the past decade 22 .

Given its moderate to slow growth over the previous decade: and the town's recently imposed large-lot zoning in rural areas, Merrimac can be expected to continue to grow at an annual rate of between one-half and one percent. High and low population estimates are provided in Table 5.

Table 5. POPULATION PROJECTIONS - TOWN OF MERRIMAC, $1980-1995$

One-half Percent Annual Growth Rate

One Percent-Annual Growth Rate

\begin{tabular}{|c|c|c|c|}
\hline 1980 & 1985 & 1990 & 1995 \\
\hline 4,451 & 4,562 & 4,676 & 4,792 \\
\hline 4,451 & 4,673 & 4,906 & 5,151 \\
\hline
\end{tabular}

Historic Preservation

Historical Perspective

The land north of the Merrimack River was originally part of a land grant established in 1638 called the "Merrimack Plantation", it was later to become the Township of Salisbury. In 1668 , the western part of Salisbury township 
was incorporated as the Town of Amesbury. A further division occurred in 1876 when, after years of deliberation, the "West Parish of Amesbury" separated, becoming the new Town of Merri$\operatorname{mac}^{23}$.

The first settlement of the town was located along the banks of the Merrimack River, in the section now known as Merrimacport. It was here that the first horse carriage shop was started around 1800. 'The carriage business grew to relatively large proportions within a few decades, culminating in the large and prosperous carriage manufacturing industry of the last quarter of the nineteenth century ${ }^{24}$."

By 1880 , a total of nineteen carriage shops had located in the town at Merrimac Center and Merrimacport. "Throughout the country, the name of a Merrimac firm on a coach or carriage was an indisputable hallmark of good design and expert craftsmanship."25

Merrimac Square was the focal point of local actịity during the latter part of the nineteenth century. Many of the larger carriage shops, carriage finding businesses and fine homes of the carriage business entrepreneurs were located there. Merrimac Square was also the site for the new Town Hall constructed in 1876, the year the town was incorporated. Today, many of these structures remain, strongly reinforcing Merrimac's historic heritage and providing charm and character to the area. In addition to their historic value to the town, many of these structures are of architectural significance, representing fine examples of Victorian Architecture. 
Merrimac Square, 1889, during the height of the horse carriage manufacturing era.

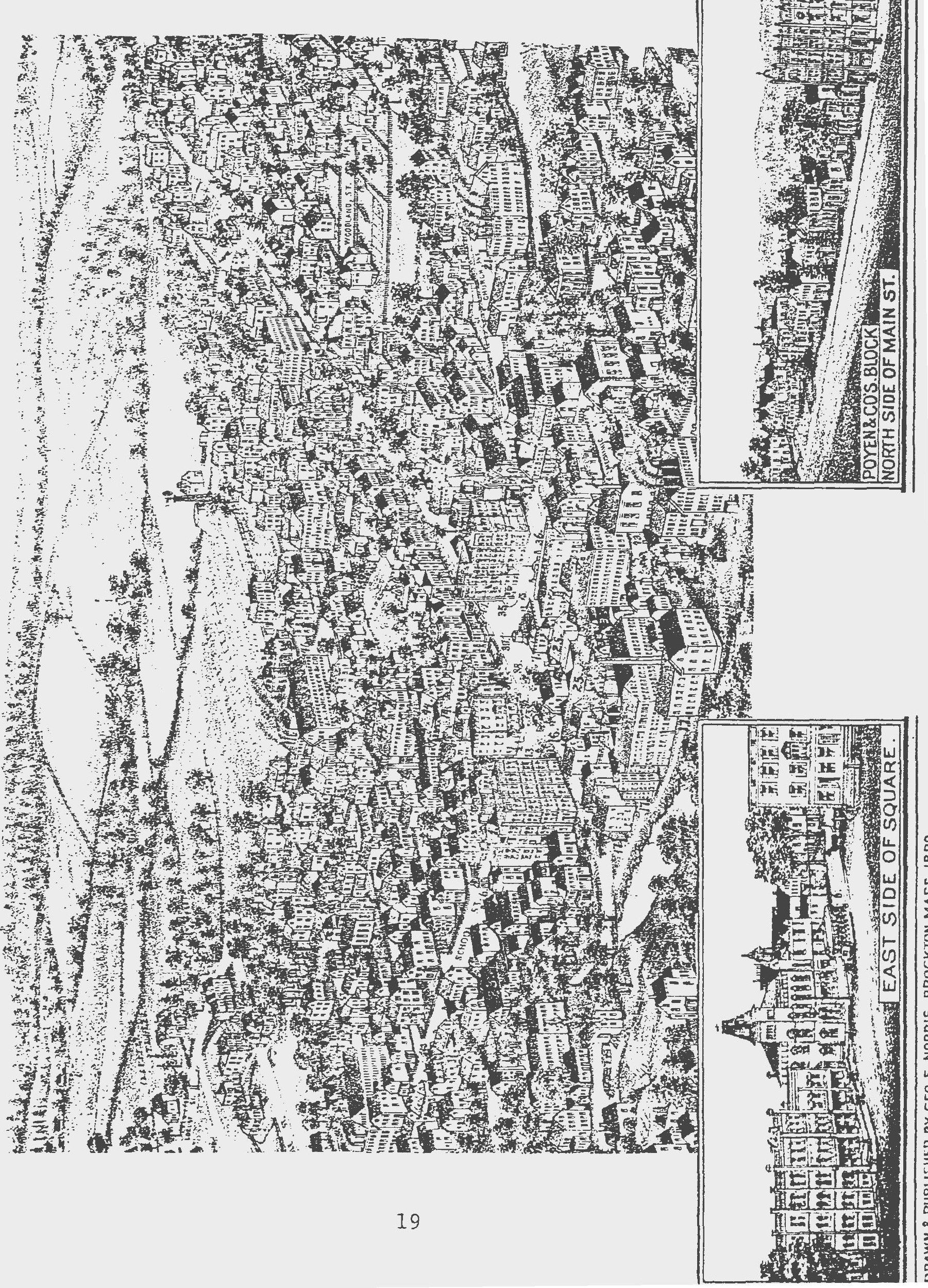




\section{Inventory}

As part of this study, a survey was undertaken to evaluate the architectural/historical significance of the existing structures in Merrimac Square (see Map 4). Levels of significance were determined using a number of criteria. These included the importance of the building to Merrimac's history, the age of the structure, the degree of alteration or removal of architectural detail and the uniqueness of architectural style.

The results produced in Table 6 show that 64 percent of the structures have high or moderate architectural/historical

Table 6. STRUCTURES OF HISTORICAL/ARCHITECTURAL SIGNIFICANCE

High

Moderate -.

Low

None

\section{NUMBER OF STRUCTURES}

11

16

8

군

42
PERCENT OF TOTAL 26.0 38.0 19.0 $16: 0$ 100.0

significance. A total of 83 percent of all structures were built prior to the turn of the century and contribute to the historic character of the study area.

In 1976, the Merrimac Centennial Commission surveyed the town's historic resources and identified those which were most significant. The following briefly summarizes the highlights of Merrimac Square according to that source ${ }^{26}$. 


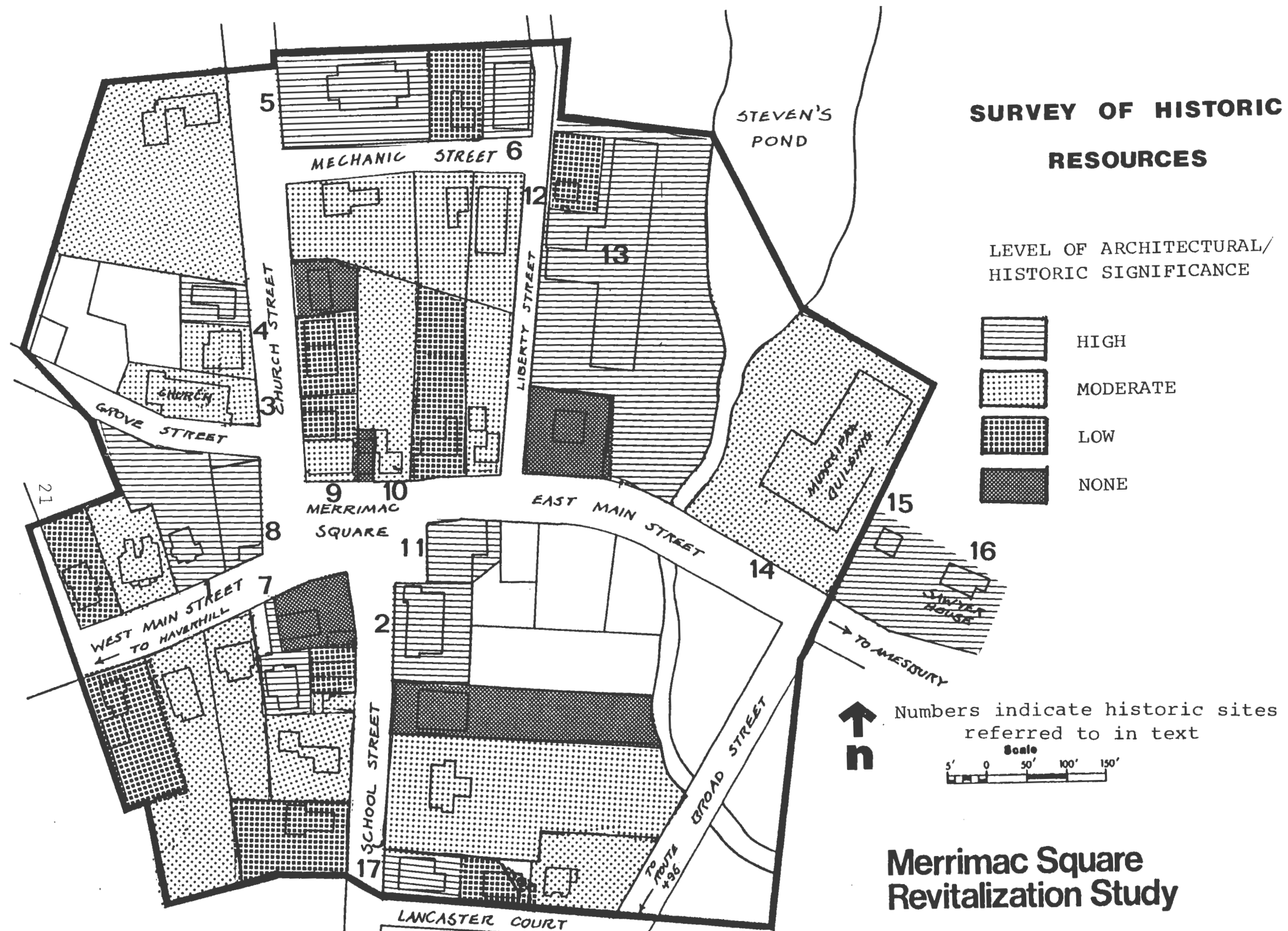

MAP 4 SURVEY OF HISTORIC RESOURCES 
1. Home of Francis Sargent (1810-1893)

This was the home of one of the principal organizers of the carriage firm of Sargent, Harlow and Company. The building was later used as a private girl's school.

2. Merrimac Town Hall (1876)

The town hall building was donated to the town by a native of Merrimac. The structure is an excellent example of American Gothic Architecture. The building still houses the Town Offices on the bottom floor and Merrimac's Town Museum on the second floor.

3. Baptist Church (1869)

The Baptist Church is also an example of Gothic Architecture. The church's steeple was trunc ated in the 1950's after considerable damage caused by several hurricanes.

4. Original Buildings of Sargent, Harlow and Company (1852)

This was the largest carriage shop business in Merrimac.

5. Pilgrim Congregational Church (1859)

This is the fourth church building to be located on the site.

6. Grange Hall (1839)

The Grange is of Greek Revival Architecture. It was originally constructed as the Third Congregational Church and was moved to its present location in 1859.

7. American Legion Hall (1890)

This building is an excellent example of Second Empire Victorian Architecture. The building served for many years as the local YMCA.

8. Poyen Block (1886)

The building was constructed by John S. Poyen, $\mathrm{Jr}$. and his business partner to house their carriage finding business. 
A SURVEY OF MERRIMAC SQUARE'S HISTORIC RESOURCES

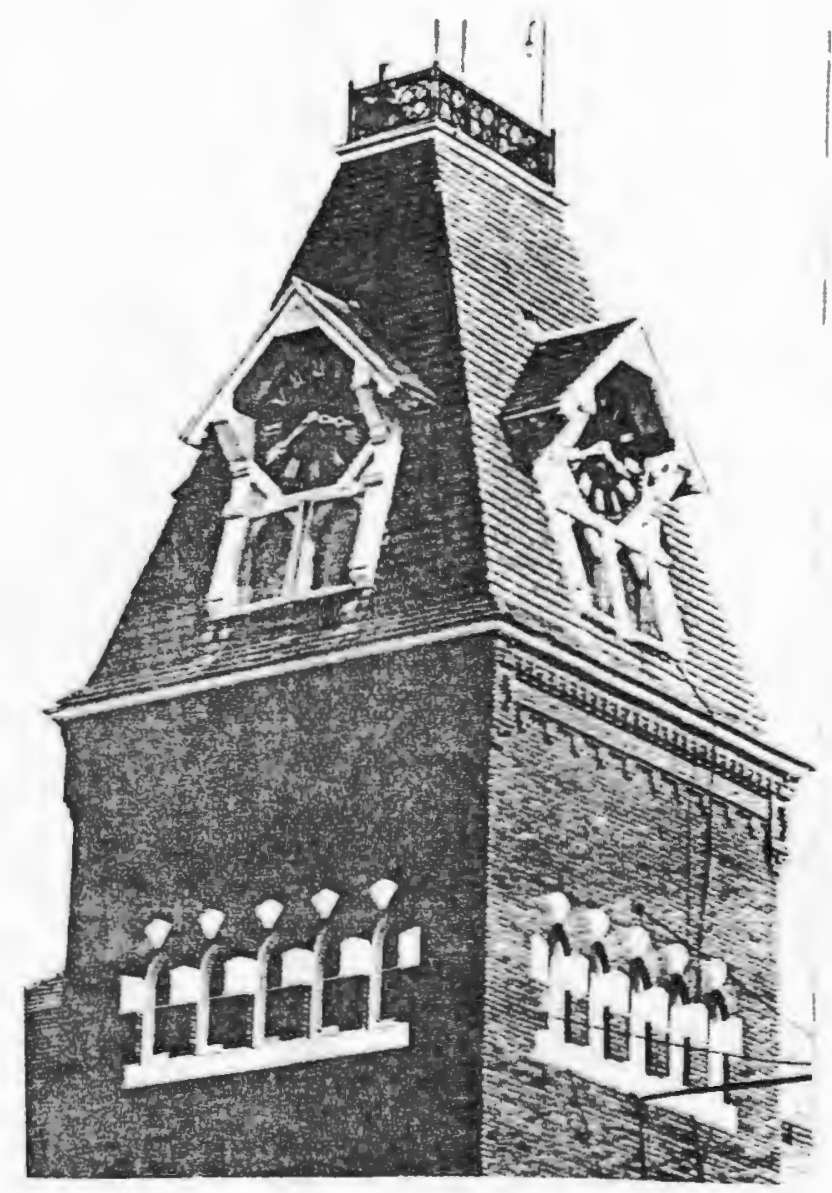

Merrimac Town Hall (2)

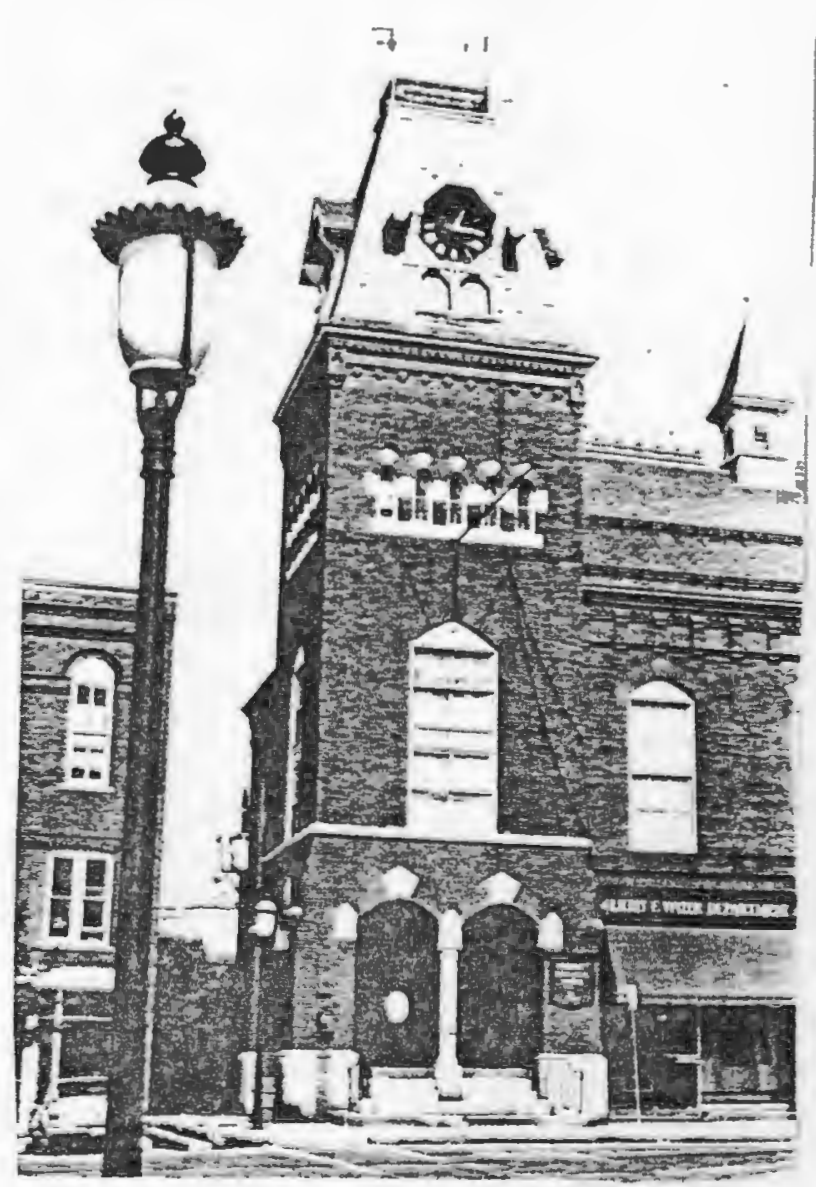




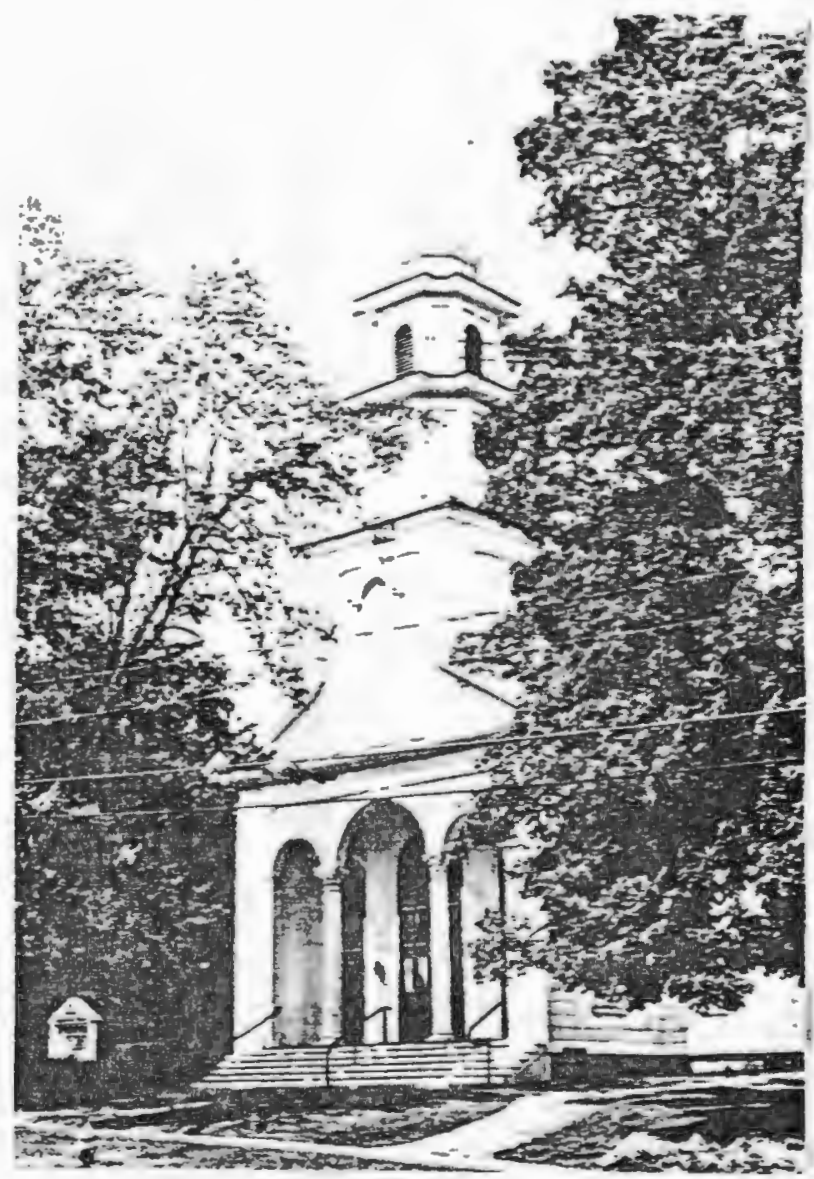

Pilgrim Congregational Church (5)

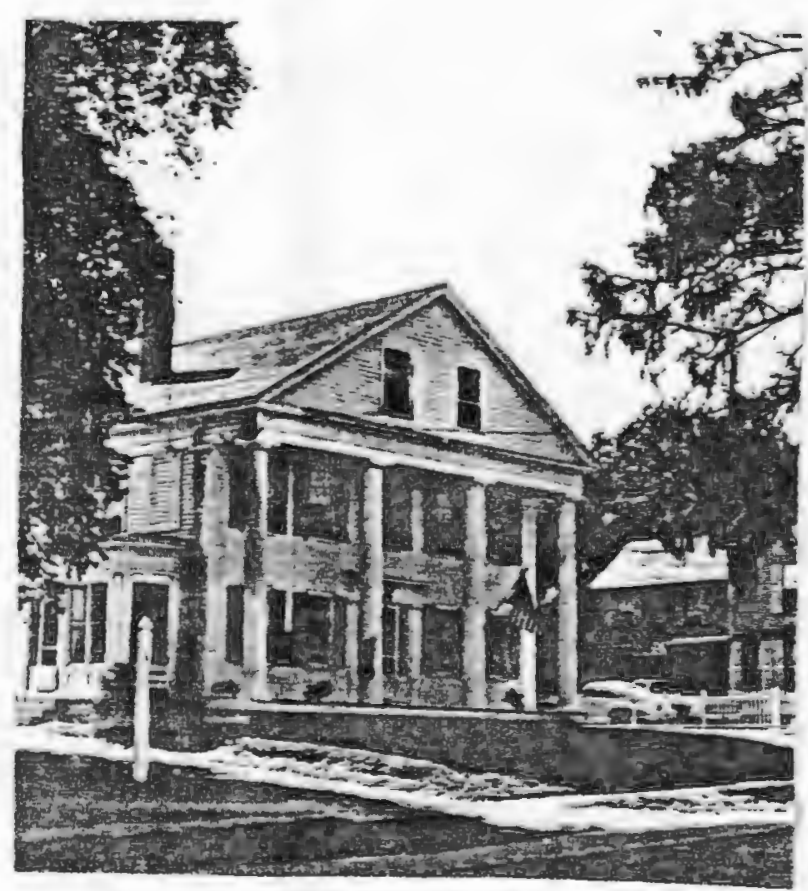

Greek Revival Home

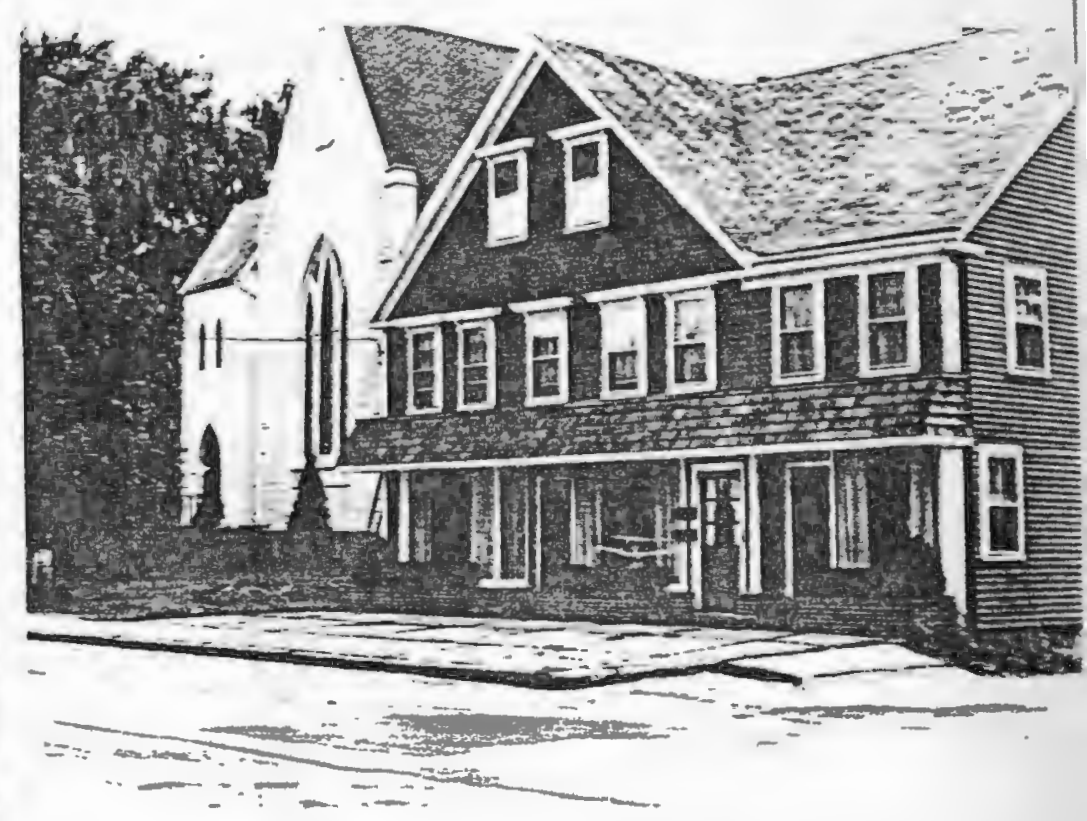

Sargent, Harlow and Co. carriage shop buildings ( 4 ) and Baptist Church (3)

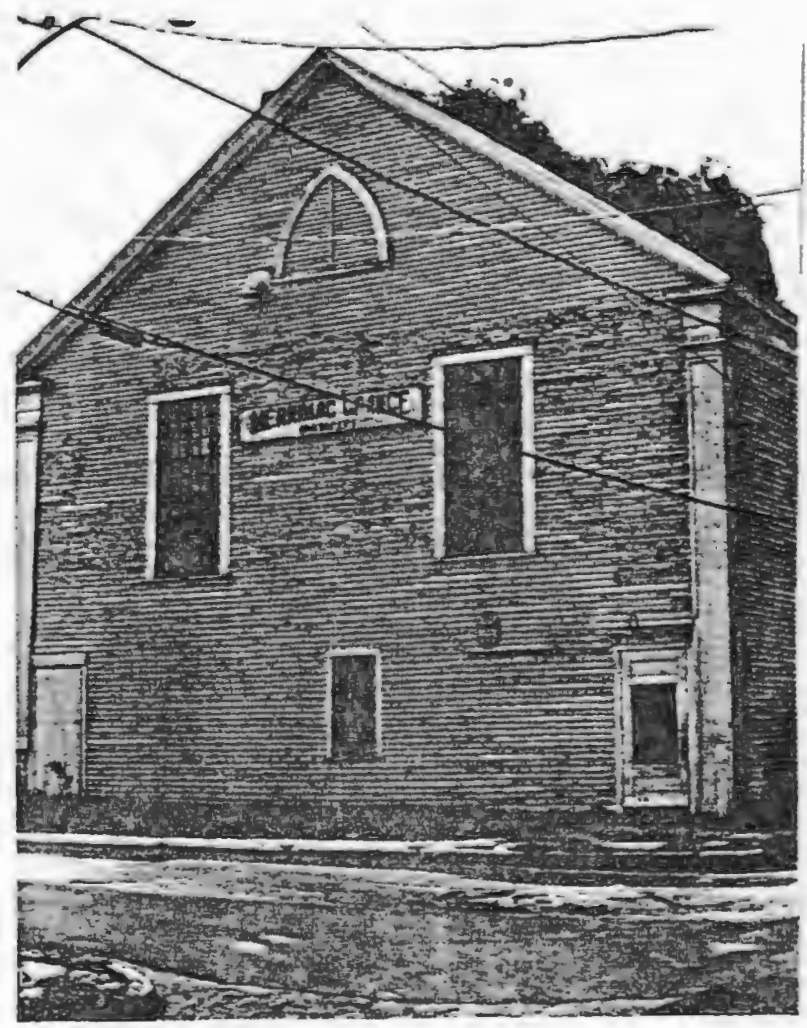

Merrimac Grange (6) 
9. Rowell Block (1896)

This brick structure was built to replace an old wood frame Post office which was earlier destroyed by fire.

10. Samuel C. Pease House

The residence of Samuel C. Pease, a carriage manufacturer.

11. Little and Larkin Block (1882)

This building accommodated another large carriage finding tusiness in Merrimac. At the turn of the century, it housed the "Merrimac Budget", a local newspaper.

12. Former Carriage Shop Building

13. Engle-Lewis Counter Company (1900+)

Originally, this was the site of the H. G. and H.W. Stevens Carriage Works Company. A fire destroyed the original structures, which were replaced by these existing buildings near the turn of the century.

14. Municipal Building (1916)

This structure was constructed by the Massachusetts Northeast Transportation Comapny to house street cars and trolleys.

15. Landing One-room Schoolhouse (1857)

The Schoolhouse was moved to School Street in 1893 and then again to its present location in 1972.

16. Old Sawyer House (1725-1770)

This 90 percent original "saltbox" house in the Georgian Style was purchased by Aaron Sawyer, a local physician, in 1757. The property is now owned by the Town Improvement Society and maintained as a local museum.

17. The Merrimac Engine House (1871)

The engine house was originally located near Steven's Pond and was moved to its present location in the 1880's. 


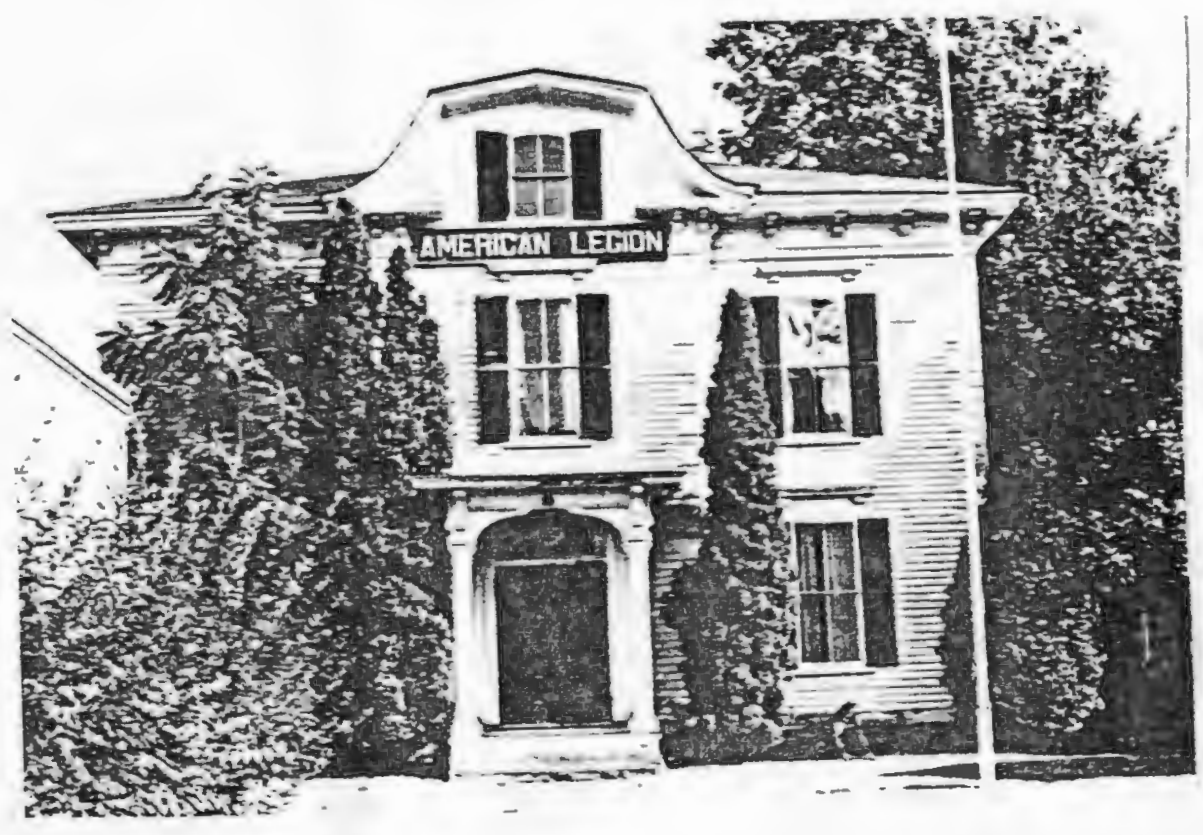

American Legion Hall (7)

Poyen Block (8)

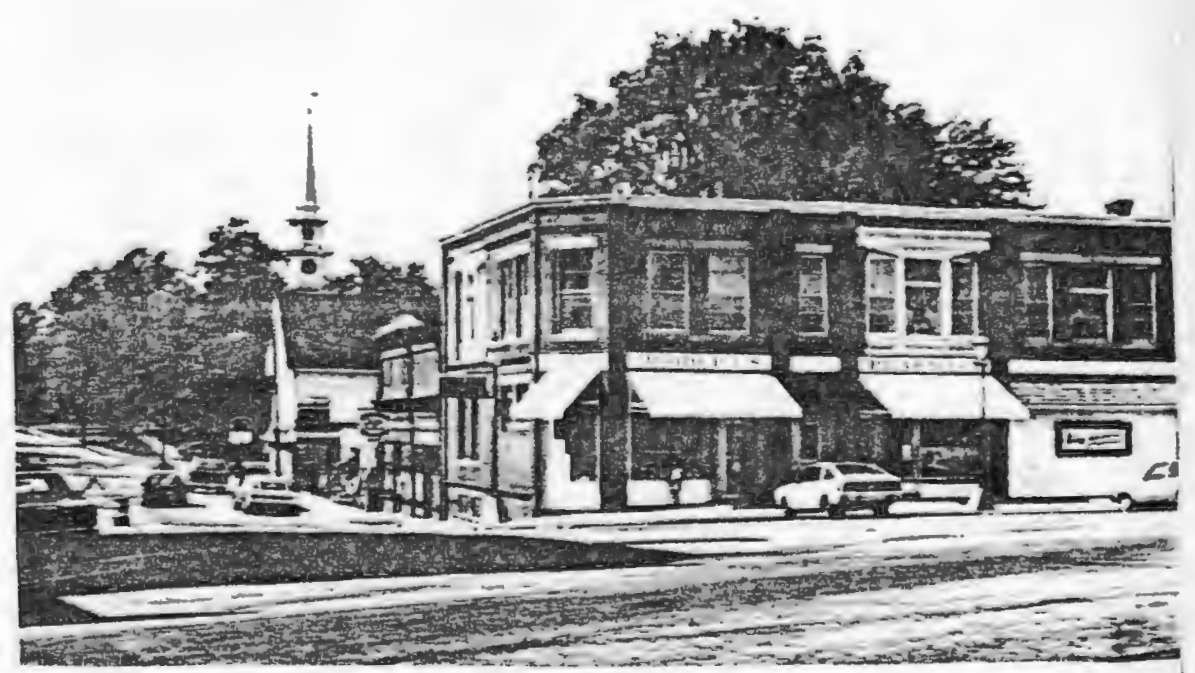

Rowell Block (9)

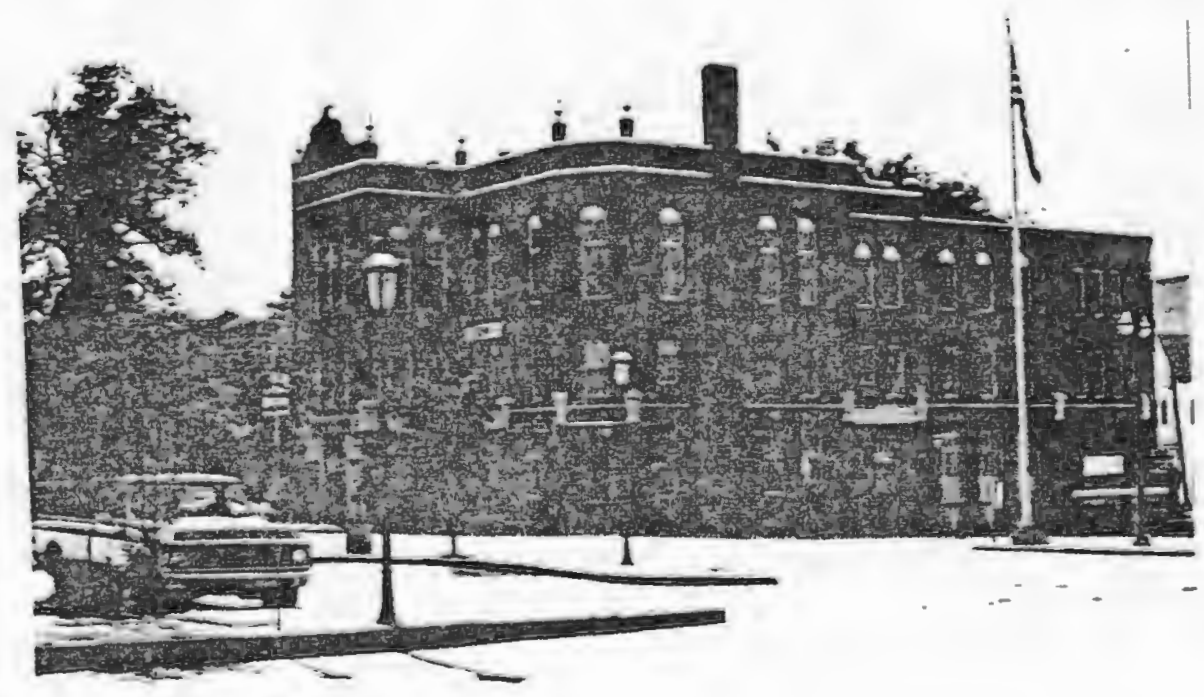




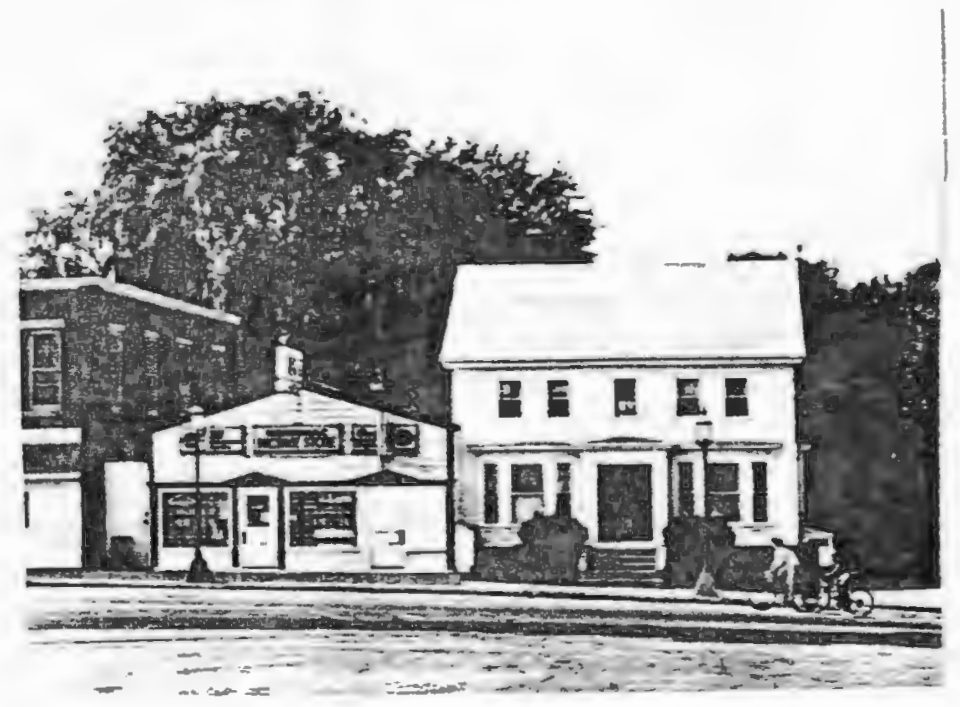

Samuel C. Pease House' (10)

Little and Larkin Block (11)

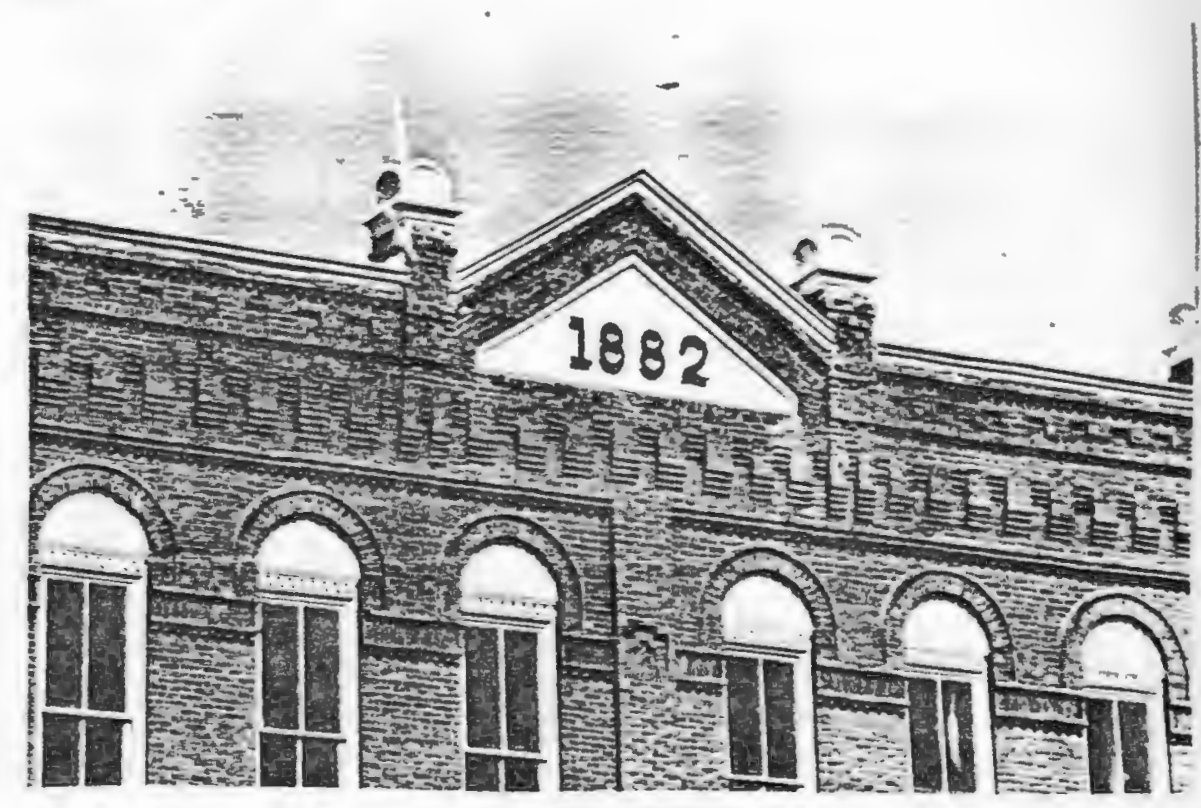

Samuel C. Pease House and Little and Larkin

Block viewed from the west.

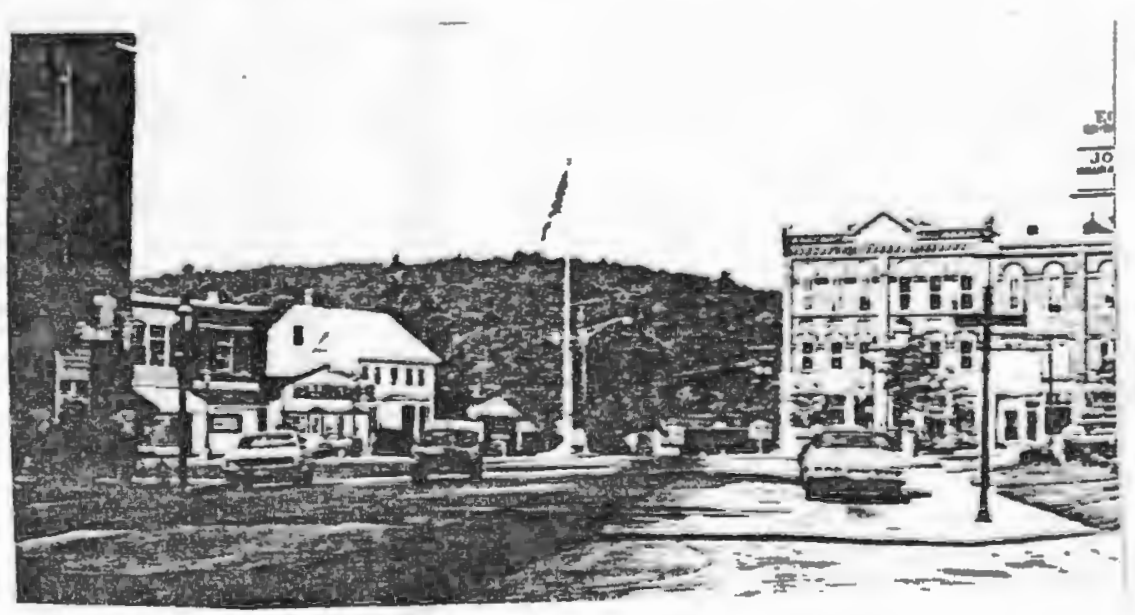

Town Hall and Little and Larkin Block
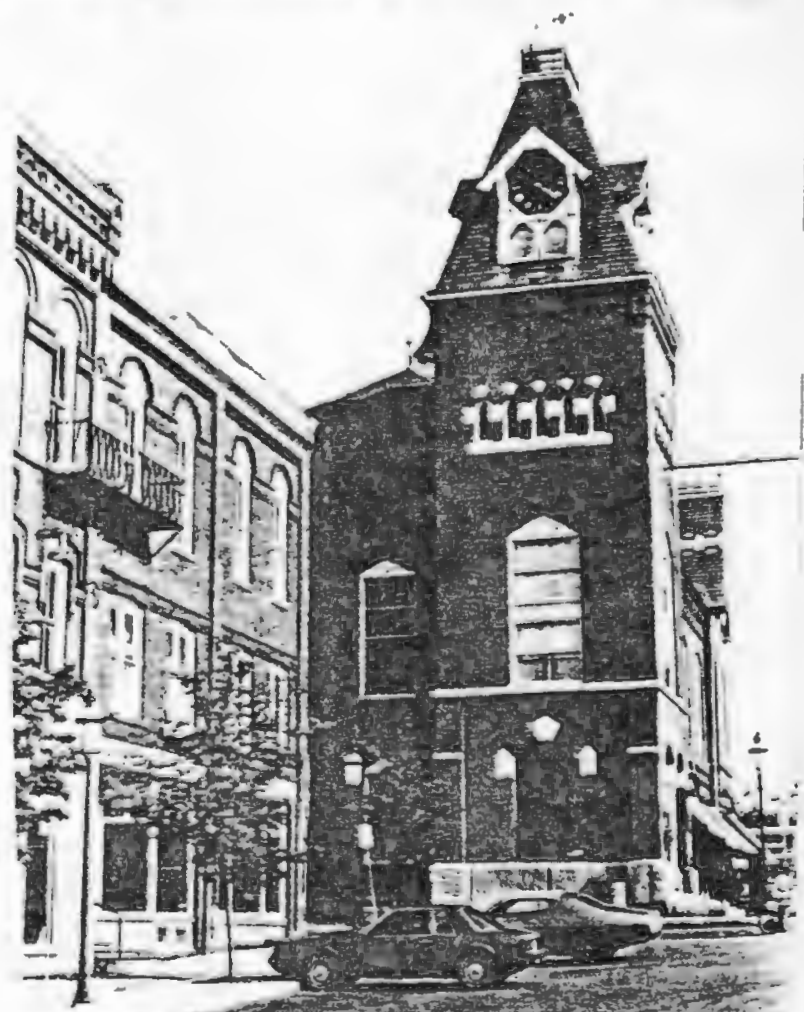


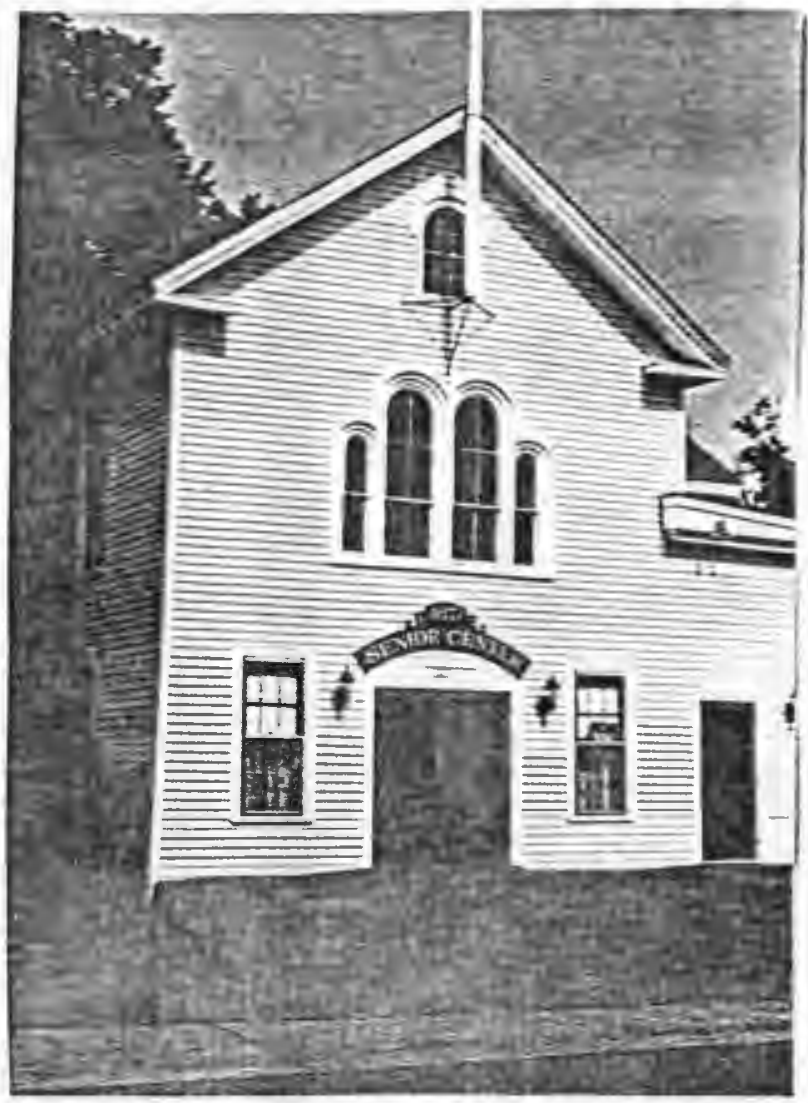

The Merrimac Engine House (17)

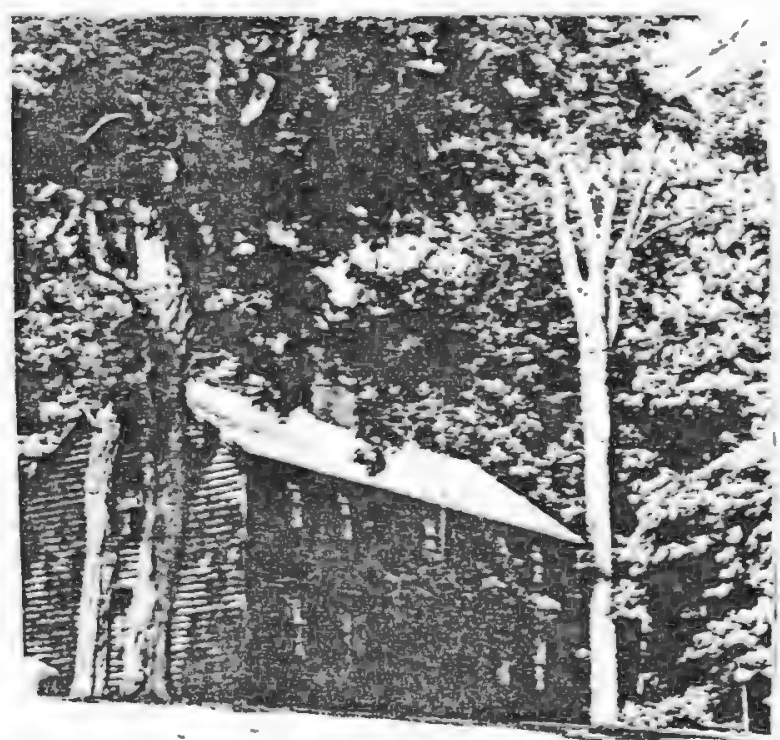

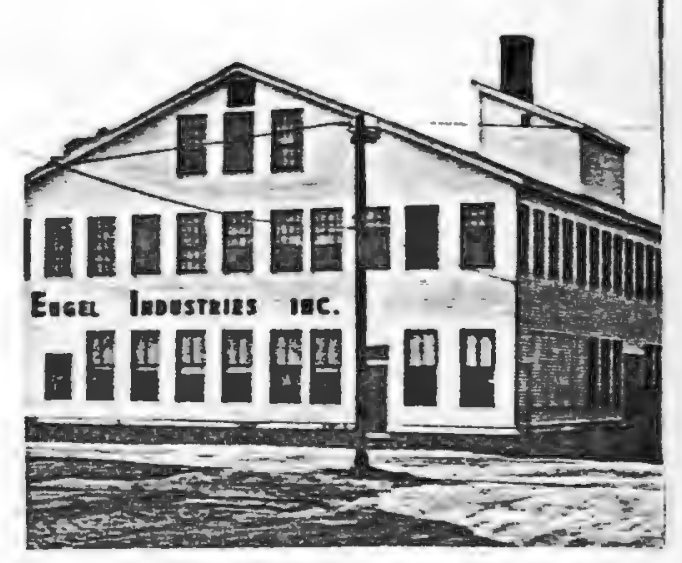

H. W. Stevens Carriage Works Company

(13)

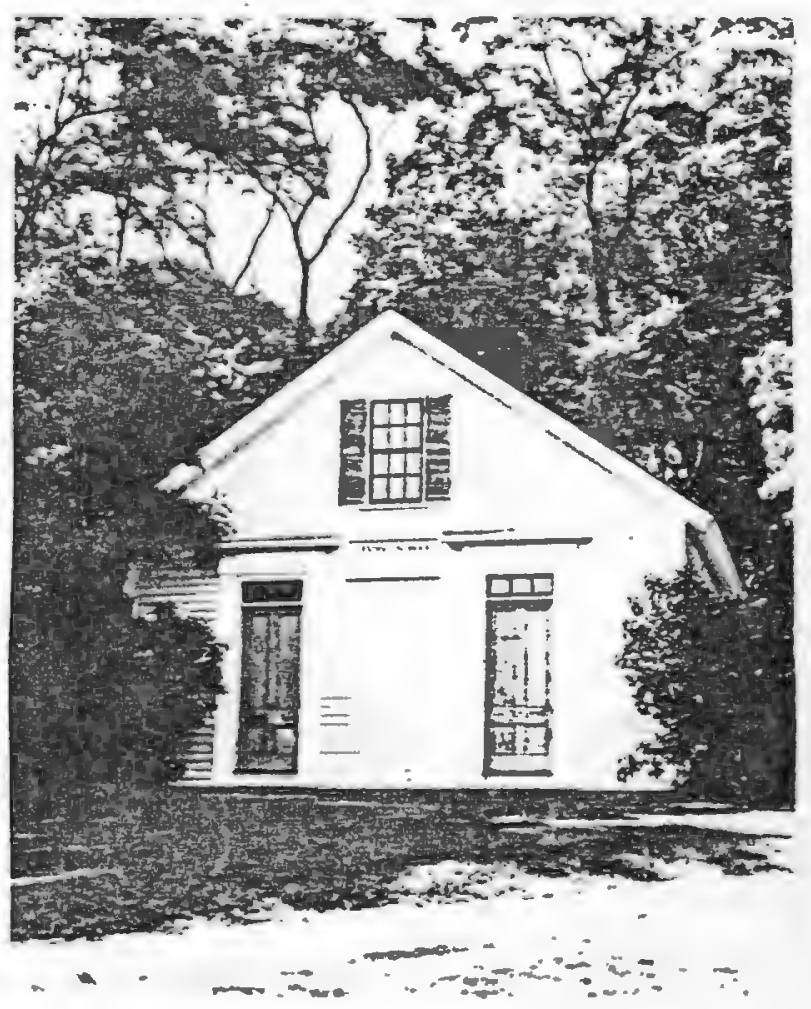

One-room School House (15)

Old Sawyer House (16) 
Historic Preservation Concerns

Clearly Merrimac Square, with its distinct historic heritage and rich architectural flavor, is a great asset to the Town of Merrimac--one which the community should protect as a valuable resource. Today, however, after 100 years of the Square's existence, there is visible evidence that the historic and architectural integrity of the square has not always been respected. Over time, buildings have been altered with little regard to their original architecture or the overall character of the area. Much of the architectural detail characterizing their Victorian style has been removed from buildings. Incompatible modern facades of inappropriate materials have been placed on some of the commercial buildings, obscuring their architectural styles. Others have been treated with aluminum or vinyl siding which, in addition to being less attractive than original clapboards, can accelerate the deterioration of the buildings.

Over the past twenty years, some of the Square's more significant structures have been demolished in the name of progress. An example is the Monomack Hotel, which once stood at the site of the Northeast National Bank. In some cases, these demolished structures have been replaced with modern construction which conflicts with the Victorian flavor of the Square.

Physical Conditions

Building Appearance Survey

A Building Appearance Survey was conducted to identify those buildings which are attractive in their present condi- 
Two examples of building facades, of uncomplementary materials and inappropriate design, which ignore the architectural features and style of the building upon which they are placed.
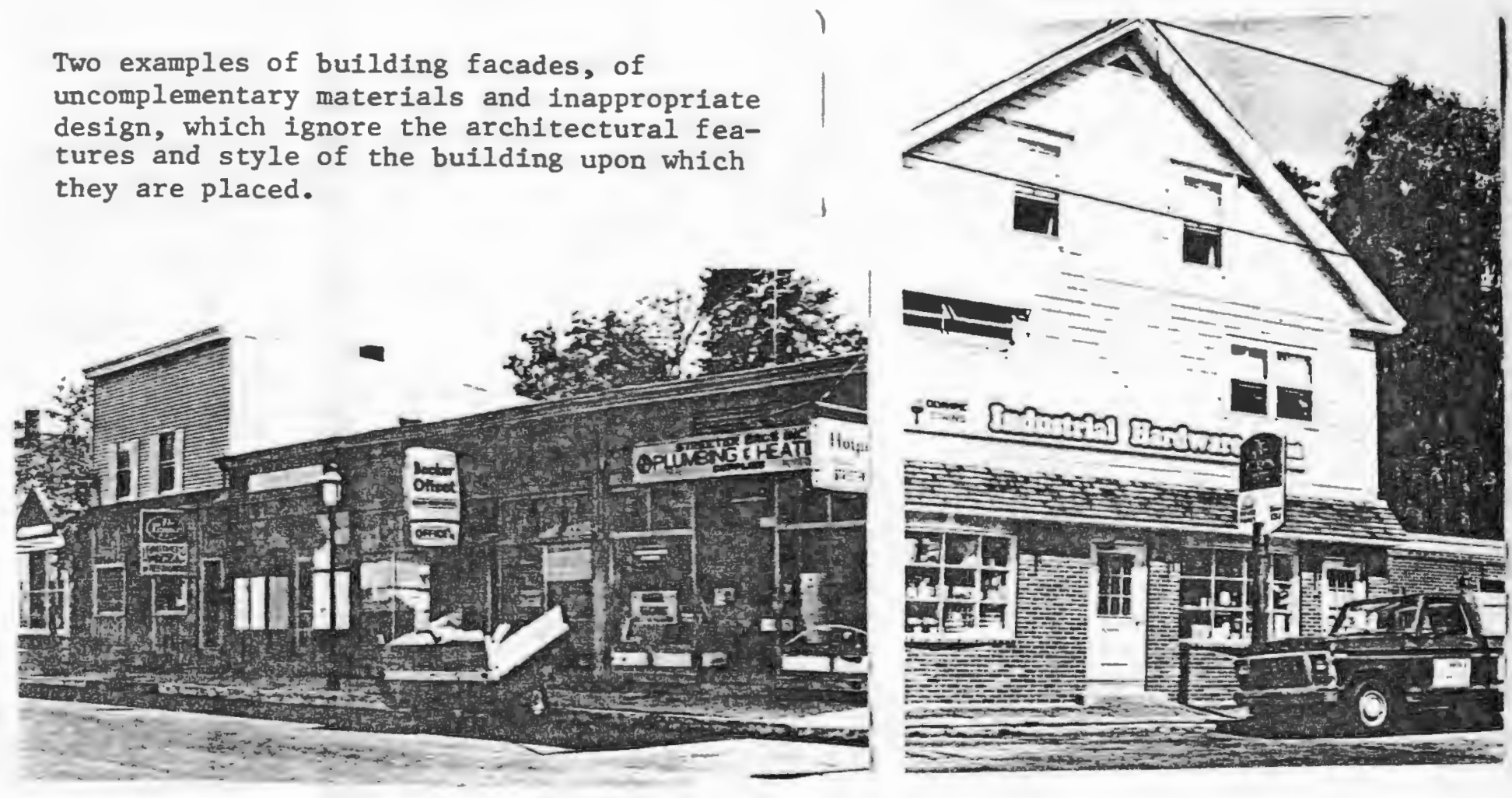

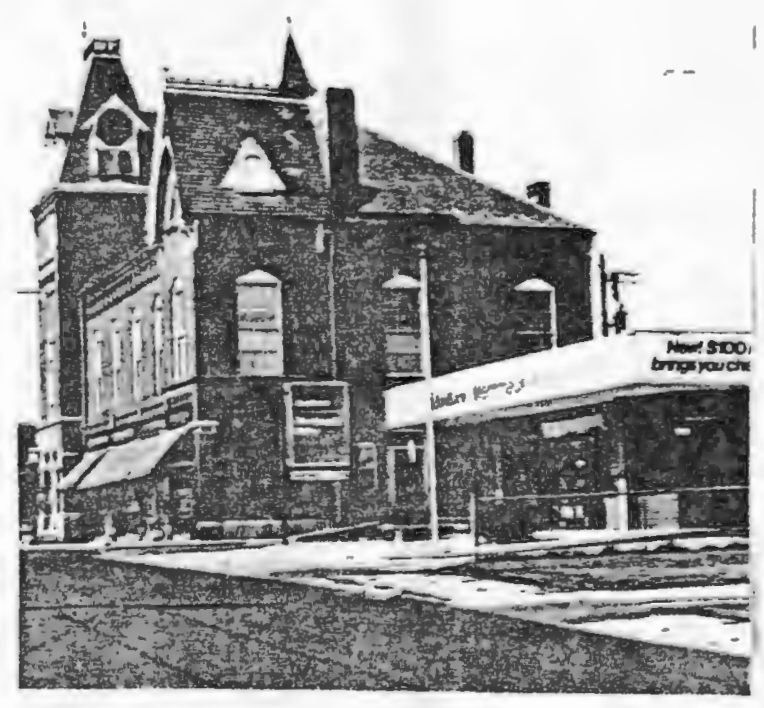

HISTORIC PRESERVATION CONCERNS
A case of where new "modern" development is out of keeping with the Victorian character of the Square.
An outstanding example of rehabilitation work which respects the architectural style of the building and reinforces the historic flavor of the area.

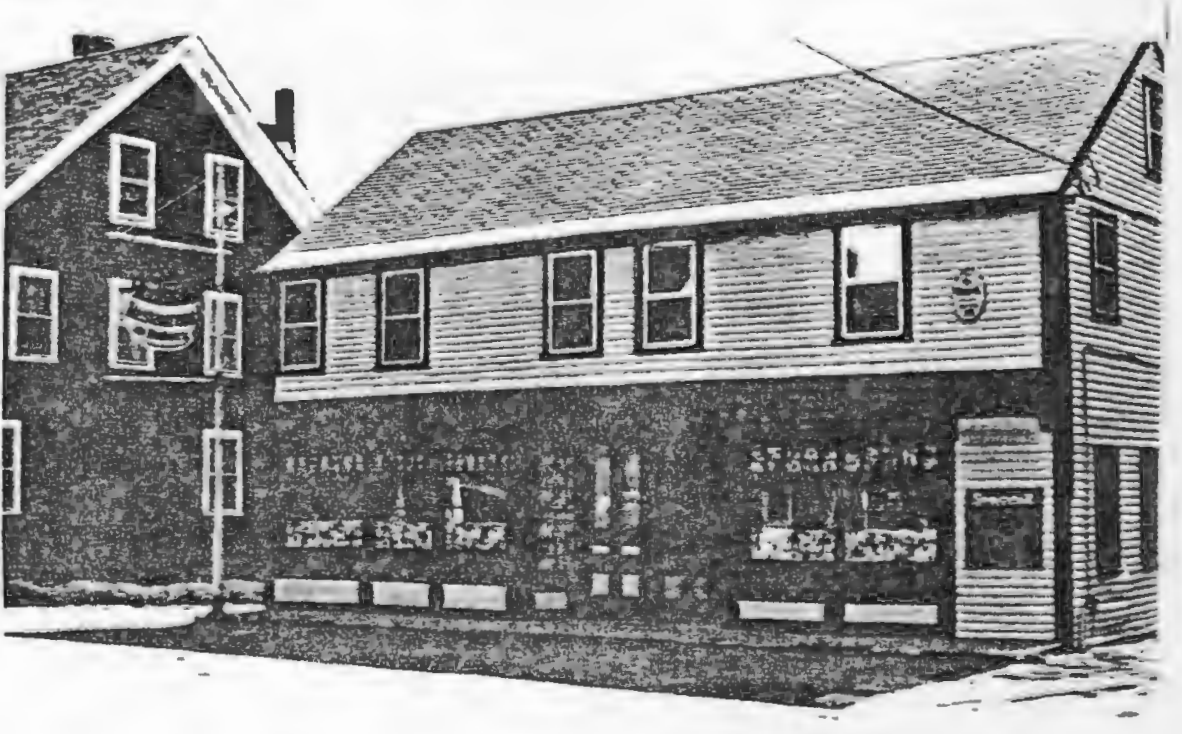


tion and those requiring corrective exterior work or superficial treatment such as painting, cleaning, repointing of bricks, or replacement of doors and windows. It should be emphasized that this survey is subjective in nature and meant only to provide an overall evaluation of building appearance. It is not intended to measure the "structural soundness" of the buildings surveyed. Such evaluations should be performed by appropriately trained professionals. Nonetheless, this survey may be used as the basis for developing a general building improvement strategy.

The following evaluation system was developed to judge building appearance:

Excellent - Newly constructed or restored, well maintained

Good - Some cosmetic attention necessary

Fair - Minor repairs needed, poor maintenance, cosmetic attention necessary

Poor - Dilapidated and substandard in appearance, major repairs needed or complete rehabilitation necessary

The results of this survey are recorded on Map 5 and in Table 7 on the following page.

The survey shows that the majority of buildings in the study area (55 percent) are in good to fair condition, while ten percent are in need of substantial rehabilitation. This finding is not surprising, considering that 83 percent of the structures in the Square were constructed prior to 1900 . 


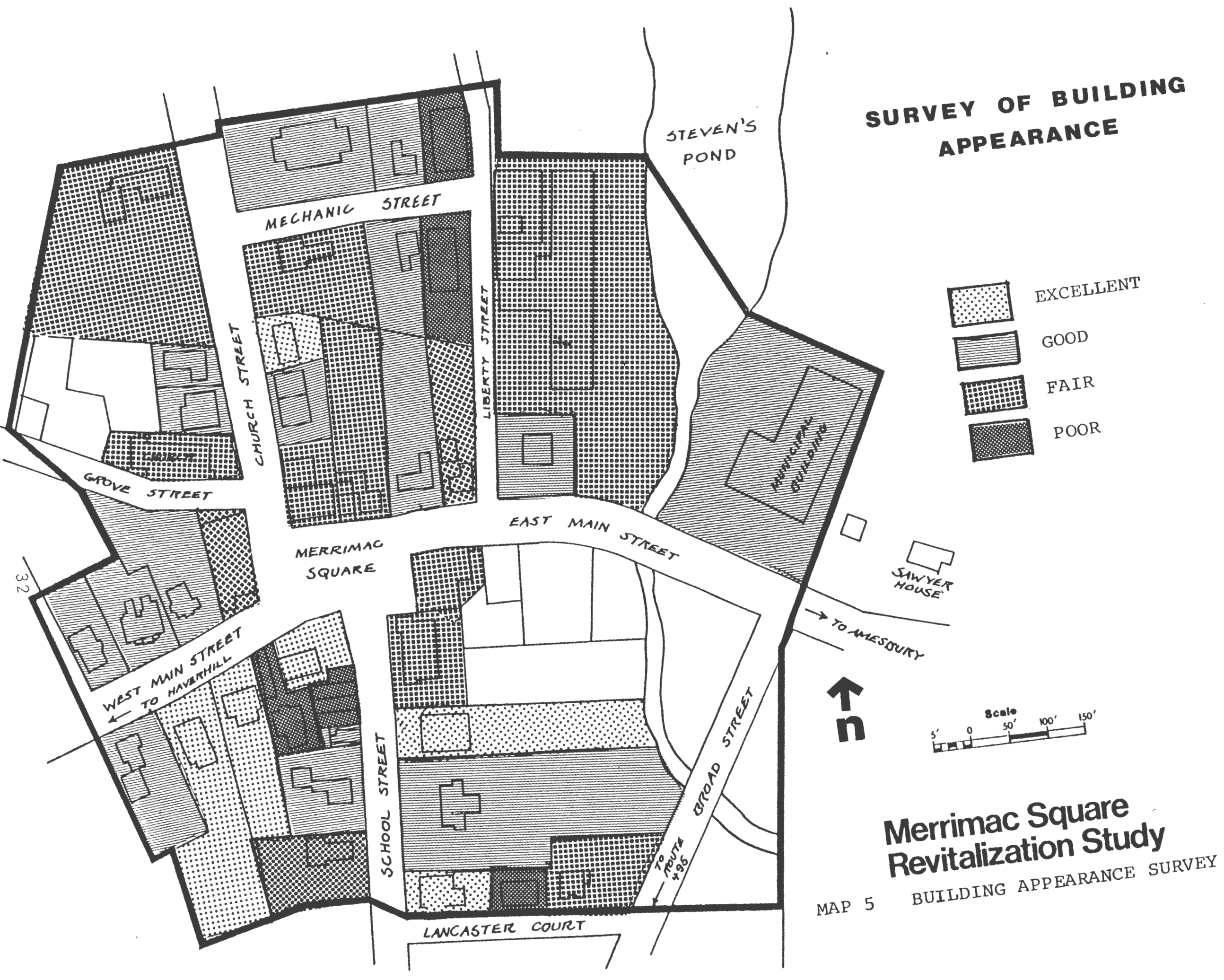


Table 7. BUILDING APPEARANCE - MERRIMAC SQUARE

CONDITION

Excellent

Good

Fair

Poor

\begin{tabular}{cc} 
NUMBER OF BUILDINGS & PERCENT OF TOTAL \\
\hline 6 & 15.0 \\
16 & 40.0 \\
4 & 35.0 \\
40 & 10.0 \\
\hline 4
\end{tabular}

\section{Infrastructure}

Merrimac Square is serviced by both water and sewer lines which are reported to be in excellent condition.

The town has nearly completed a 7.9 million dollar sewer construction and secondary wastewater treatment facility project, which has included the installation of all new lines in the Square area.

Presently, Main Street is served by a 12-inch water main, while Church and School Streets are served by a sixinch line. The capacity of existing sewer and water services is adequate to meet additional demand generated by any proposed development envisioned in this revitalization plan ${ }^{27}$.

Generally, streets and sidewalks in Merrimac Square are in fair to good condition. An exception exists on Mechanic, Liberty and Lancaster Court where sidewalks are in a state of disrepair and should be replaced. Those streets affected by the sewer construction are in poor condition and should be resurfaced. 
Signs

Signs are very important to a downtown because they serve to identify stores and businesses and advertise the merchandise sold within. Well-maintained and coordinated signs, designed in good taste, will project a positive image of a shopping district, as an attractive, well-maintained and economically viable area offering high quality goods and services. Conversely, uncontrolled, chaotic and poorly designed signs will project a negative image of an unattractive, economically declining downtown area offering low quality merchandise.

Generally, the signs in Merrimac Square are of reasonable size and design. Signs on the Town Hall, Senior Center and Home Haven Restaurant are exceptional examples of good design. They are small in size, well proportioned, clear, concise and compatible with the architectural features of the buildings and their surroundings. These signs become an integral part of the buildings and contribute to Merrimac Square's flavor and character.

However, there are also some examples of poor signage present in the square. For example, the uncoordinated and plastic lit signs on the liquor store are cluttered in appearance, confusing to the observer, and inappropriate in design and materials. Such signs detract from the aesthetic quality of the area. 


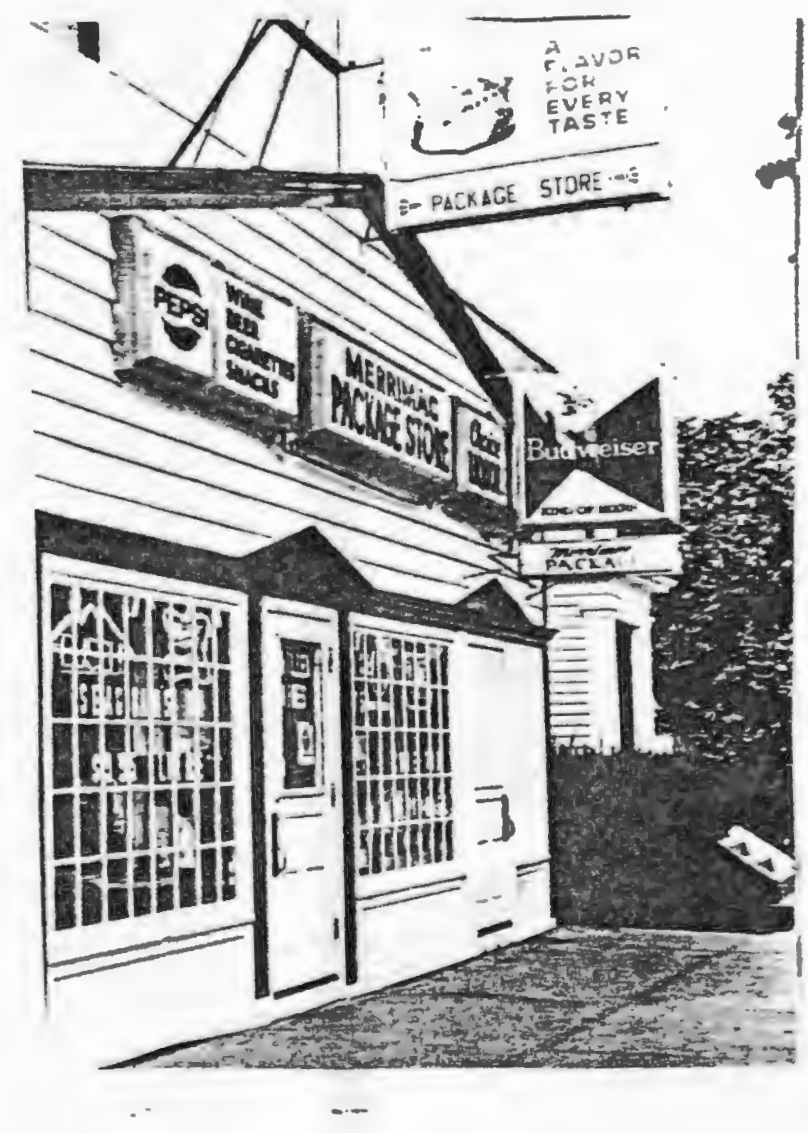

\section{SIGNAGE}

An example of signs which are made of unattractive materials and are out of proportion with the building's facade.

Too many signs placed on this storefront, present a cluttered, uncoordinated and chaotic appearance to the business they serve to advertise.

In contrast, an example of tastefully designed signs, of appropriate material, size and style, which complement the exterior of the building.

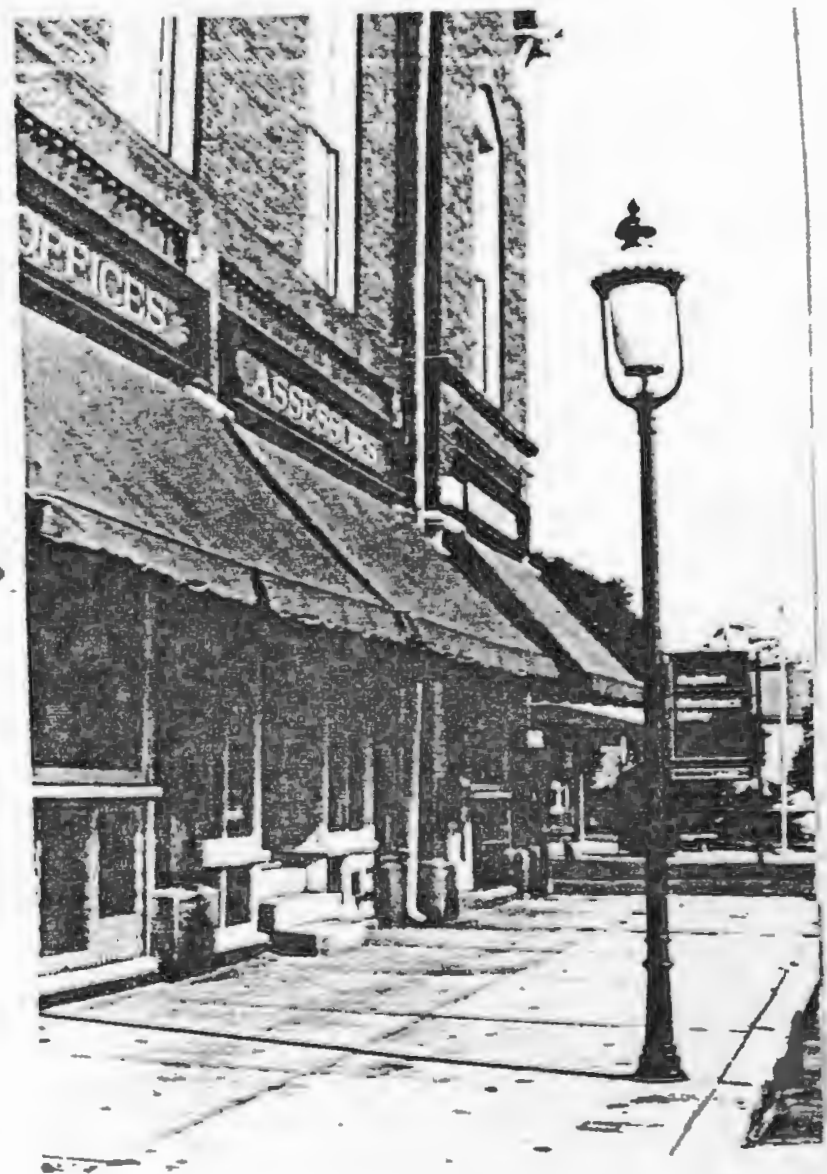




\section{Land Use and Zoning}

\section{Land Use}

Merrimac Square serves as the focal point of business, institutional and governmental activity in the town. It contains a rich diversity of land uses, as illustrated on Map 6 and in Table 8.

Table 8. LAND USE BY TYPE - MERRIMAC SQUARE

ACRES PERCENT OF TOTAL

$\begin{array}{lcr}\text { Commercial } & 2.26 & 14.0 \\ \text { Mixed Commercial/Residential } & 2.02 & 13.0 \\ \text { Residential } & & 8.8 \\ \quad \text { Single-Family } & 1.41 & 24.0 \\ \quad \text { Duplex } & 3.78 & 12.0 \\ \text { Public I } & 1.93 & 4.0 \\ \text { Quasi Public } & .64 & 10.0 \\ \text { Industrial } & 1.54 & 14.0 \\ \text { Vacant } & 2.20 & -.- \\ \text { Public Right of Ways } & 2.42 & 100.0 \\ \text { Total Acreage of Study Area } & 18.20 & \end{array}$

The study area contains approximately 18.2 acres, including public right of ways, of the total land area, 27 percent is devoted to commercial or mixed commercial uses. These provide a wide range of convenience goods and services to Merrimac residents. A list of these goods and services is provided in Appendix A. 


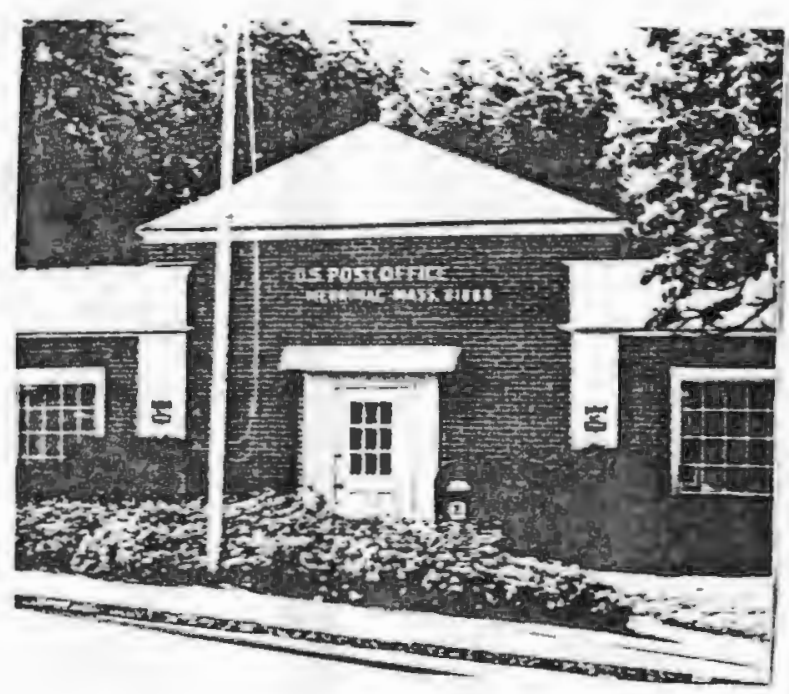

Diversity of Merrimac Square's Land Uses
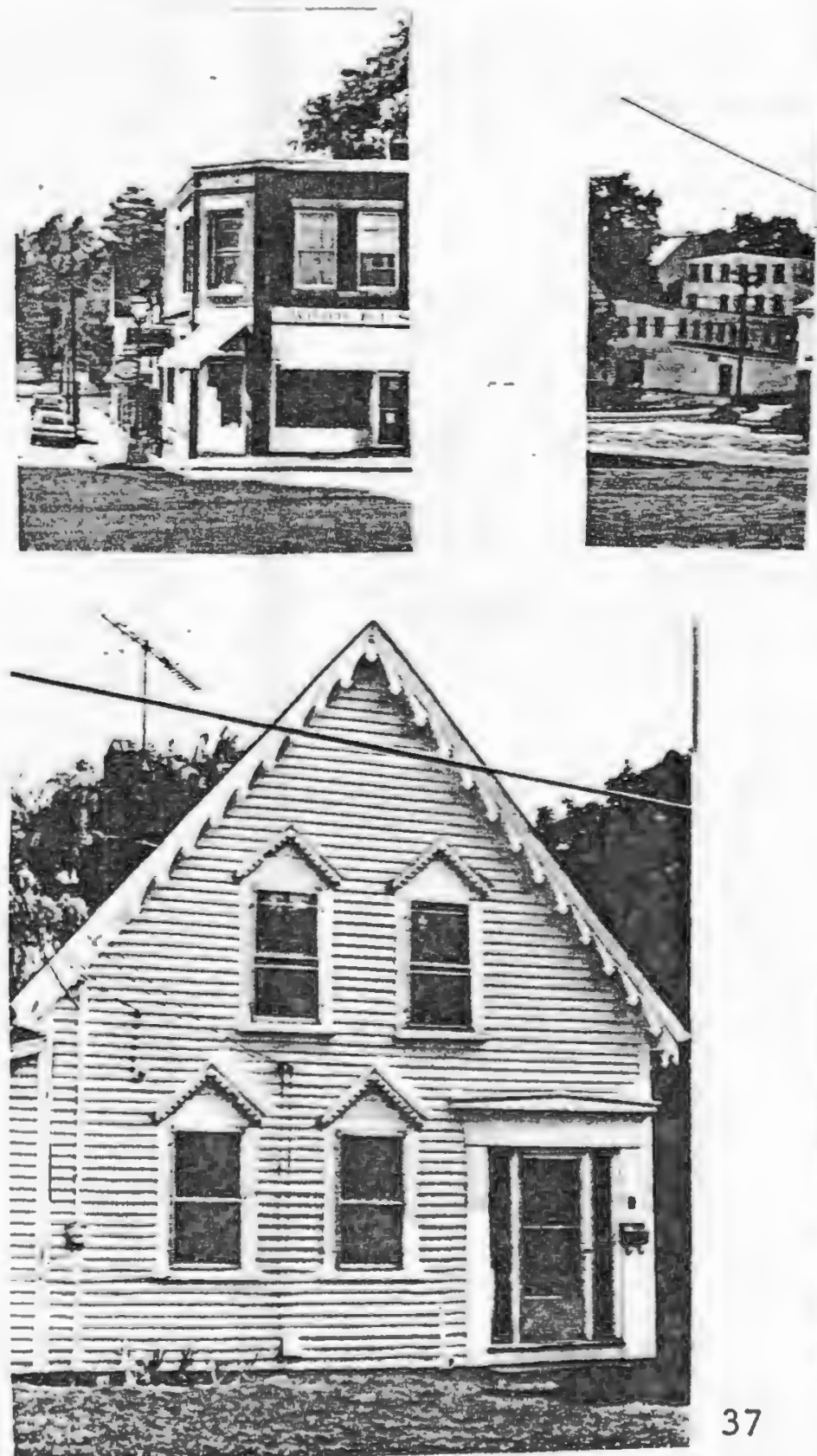
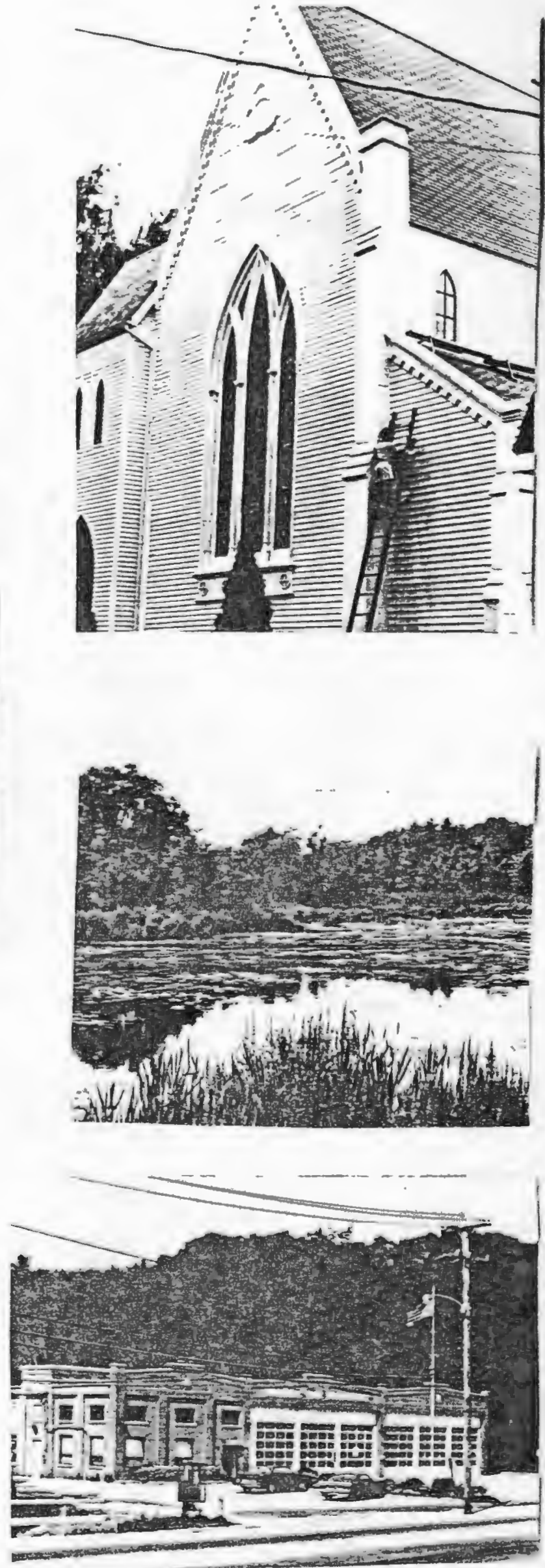


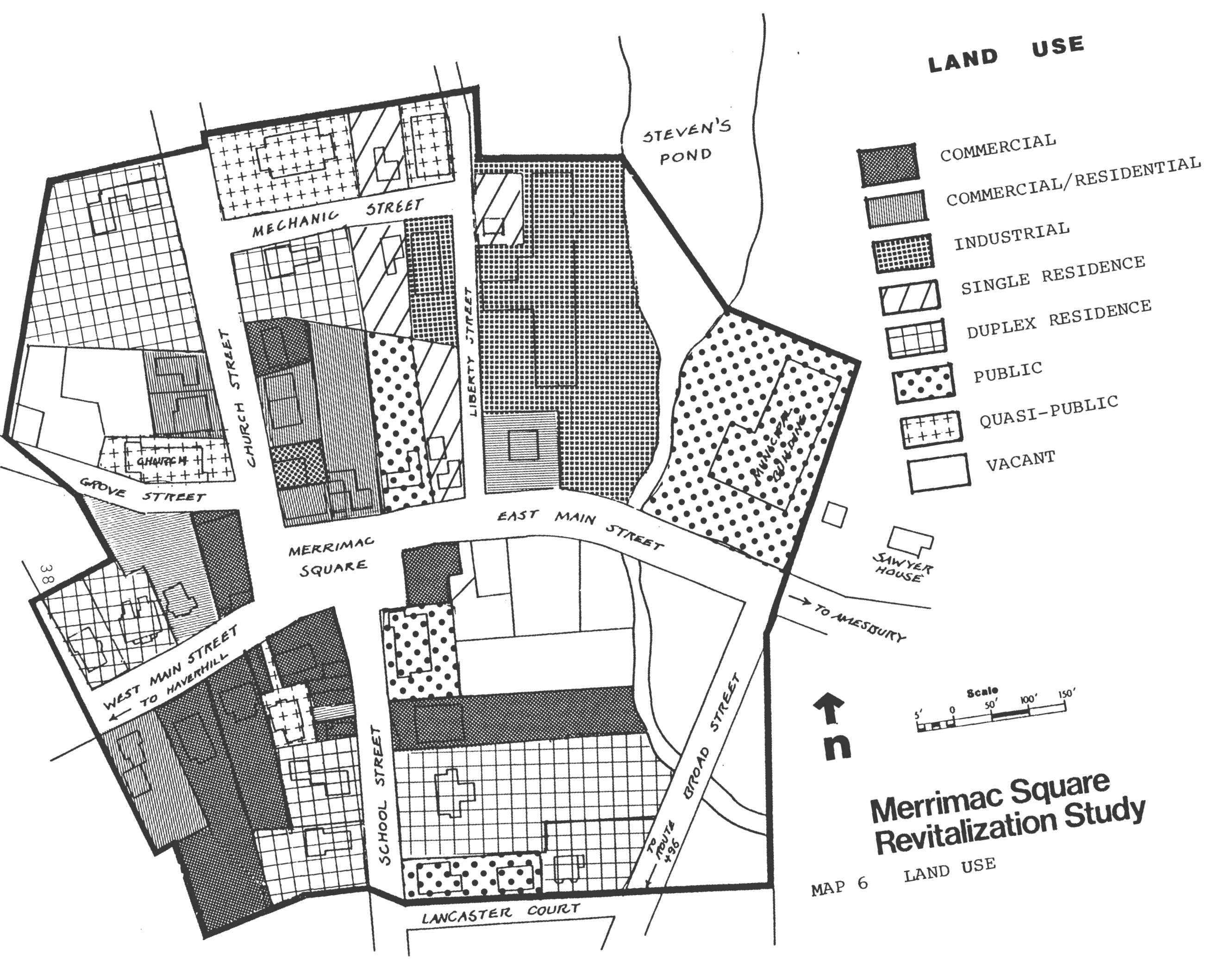


All commercial uses are clustered at the intersection of Route 110 and Church and School Streets.

Residential land uses represent the largest land use category and comprise 33 percent of the study area. The majority of residences are duplexes. Many of the residential structures were built duing the latter part of the nineteenth century on lots less than 10,000 square feet. Residential uses are located on the periphery of the Square.

Within the study area, 2.2 acres or 14 percent of the land area is vacant. Most of this land is marginal for development due to the severity of topography, presence of wetlands and/or lack of suitable access. A few sites, however, are suitable for development. These include the land behind Town Hall, the parcel adjacent to Hoyt's Hardware, the vacant corner of Broad Street and Route 110 and the area behind the Post office.

Public uses make up 12 percent of the district and include the Town Hall building, the newly renovated Municipal Brilding, Senior Center and vacant parcel off Broad Street. Semi-public lands comprise four percent of study area and include the two churches and American Legion property.

Approximately ten percent of land is industrialiy classified and is presently occupied by Burlington Medical Supplies and Wolverine Industries. Zoning

New development in the Town of Merrimac is governed by the Towr.'s Zoning Laws, amended July 1, 1978. See Map 
ZONING DISTRICTS

$1 \times x$ Industrial

Wol Commercial

$\equiv$ Residential

17. Suburban Residential

$\square$ Agricultural Residential

\section{MERRIMAC ZONING MAP}
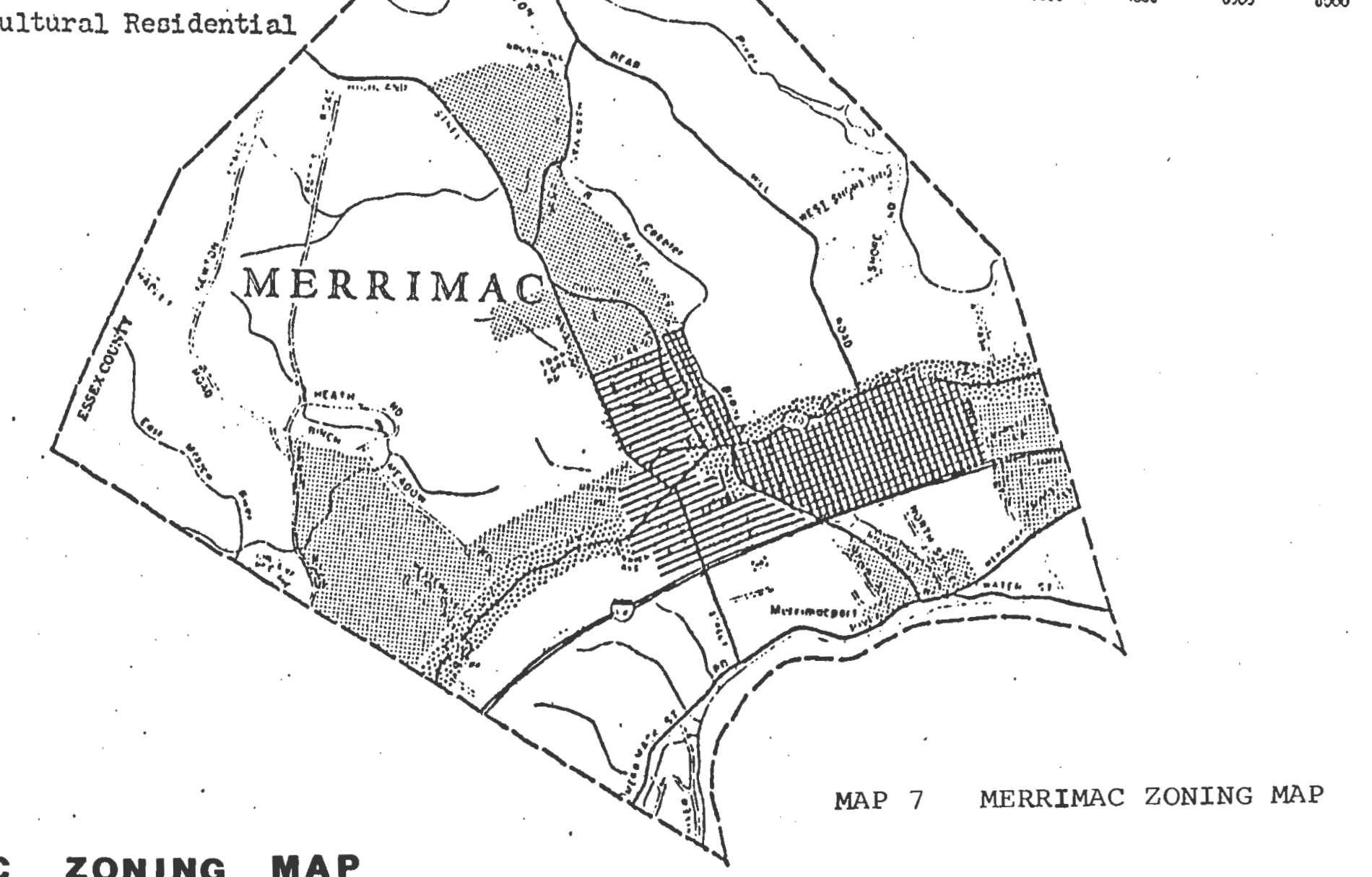
7 for classifications.

The study area coincides with three zoning districts: Comercial, Residential and Industrial as indicated on Map 8. The majority of the study area is zoned for commercial uses (75 percent). About 20 percent of the town center is zoned for "Light Industrial" uses and the remaining five percent is zoned for residential uses. The following section discusses the allowable uses within these districts and identifies inherent problems with existing zoning regulations.

Comercial District - Residential, office, restaurants, retail uses and farms are permitted in this zone ${ }^{29}$. There are no lot size or dimensional requirements for comercial uses. However, a fifty (50) foot side yard must be maintained where a commercial use abuts a residential neighborhood. While the Board of Appeals determines "adequate" provisions for off-street parking, actual standards are not incorporated in the zoning ordinance. There are no provisions for the review of site plans to ensure adequate access/egress, landscaping, architectural control, off-street loading or protection of the historic quality of the area. Signage is subject to provisions of a sign ordinance which dictates size requirements but fails to regulate use of materials or visual/design considerations Light Industrial District - Residential uses are prohibited from this zone. Although classified as a "light" industrial zone, any lawful industrial, manu- 


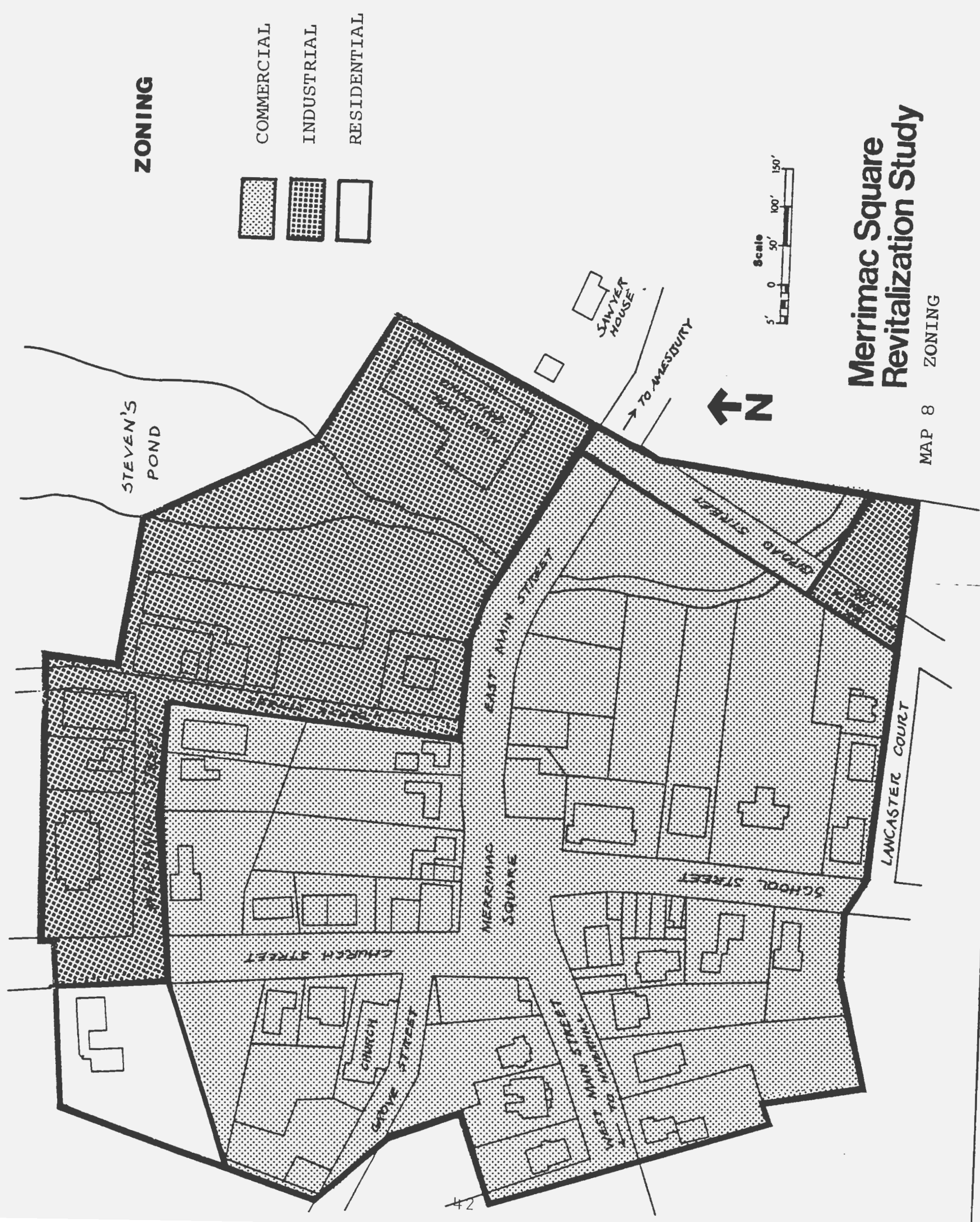


facturing, warehousing and utility use is permitted. No performance standards exist to limit external nuisance impacts of industrial uses, such as noise, pollution, odor or safety, nor do any specific provisions exist for the protection of adjacent neighborhoods such as buffers or setback requirements.

Residential District - The remaining five percent of the study area is zoned for residential uses. Single-family homes and duplexes are permitted within the Residential zone. Moderate densities are allowed on lots greater than 10,000 square feet. Accessory uses including boarding homes and customary home occupations are allowed. Apartment buildings and a variety of other uses including offices, hospital, airports and dog kennels are allowed in residential zones by special permit granted by the Board of Appeals. Although these uses are subject to special conditions imposed by the Board of Appeals, such provisions are generally minimal and offer little protection against such potentially imcompatible uses.

\section{Transportation}

Traffic and Circulation Analysis

Map 9 illustrates the hierarchy of streets and average daily trip ( $A D T$ ) volumes for the Merrimac Square area. East and West Main Street (Route 110) is the area's major thoroughfare, with an average daily trip volume of 6,100 vehicles 30 . Broad Street is also classified as a minor arterial roadway, 


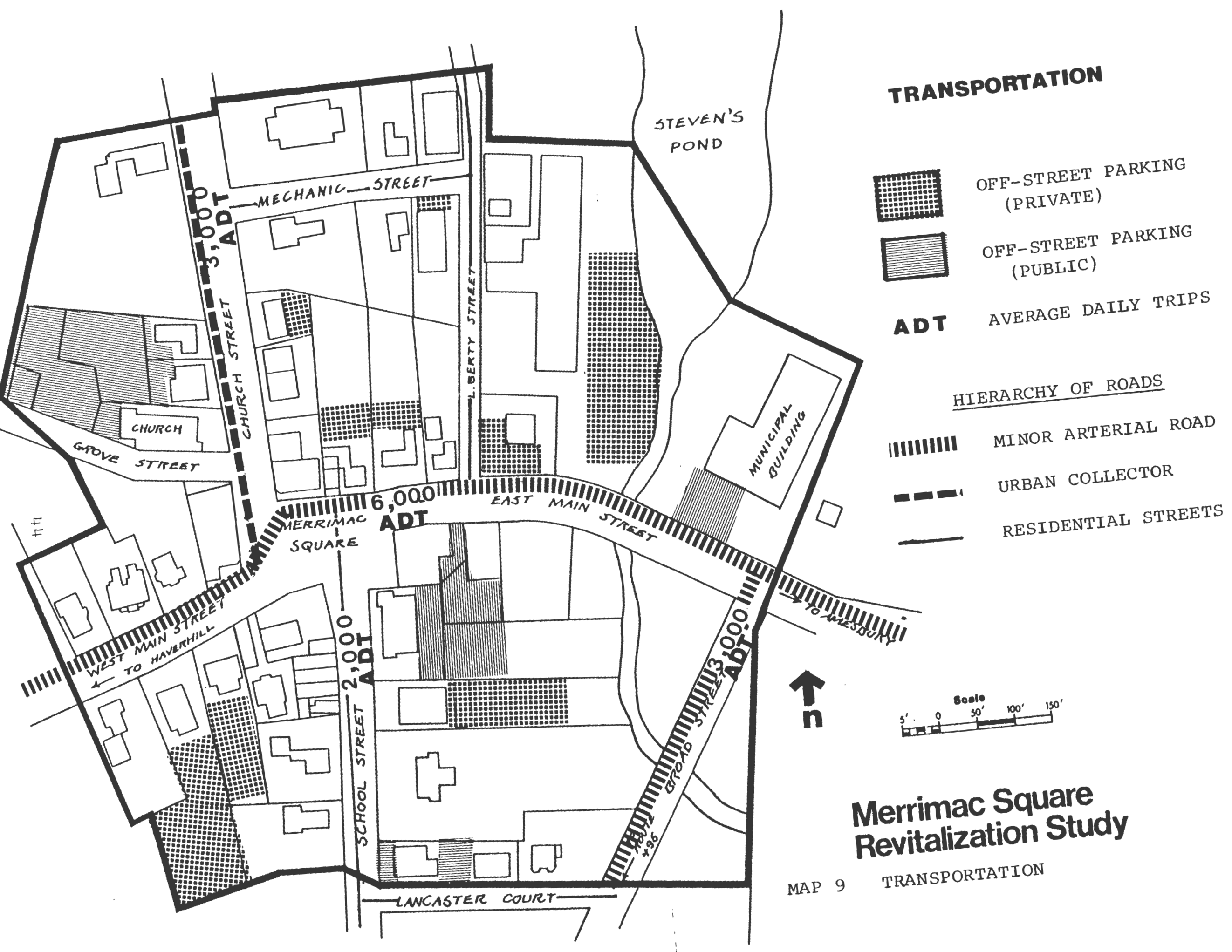


as it provides the only town access to Interstate Route 495. Church Street is a major collector linking the square with Newton, New Hampsire. The remaining streets are residential, with (ADT) volumes of less than 1,500.

The existing roadways adequately meet present traffic demand, with little or no traffic congestion. However, at intersections where high traffic volume streets meet, there is a potential for traffic conflicts. Such areas exist at the intersections of Route 110, Church and School Streets, and Route 110 and Broad Street. The Town of Merrimac's Proposed Areawide Topics Plan, prepared in 1972, reported four accidents at the former location and three accidents at the latter location during $1971^{31}$. While specific recomendations were made to correct safety problems, and improve traffic conditions at these locations, to date these proposals have not been implemented.

The following outlines major traffic concerns and problems at these locations as identified in the Topics Plan and confirmed by recent observations.

Broad and West Main Streets

Traffic volume on Broad Street, the access route to Interstate 495, is considerable. At present, a control island and flashing light is present at this intersection. The Municipal Building, which houses the police, fire and highway departments, lies adjacent to this location. Departure of emergency vehicles presents a potential traffic hazard. A traffic light synchronized with the alarm system, directional signs, identification signs 
and striping to define turning lanes are needed at this intersection.

Route 110/Church Street/School Street Intersection

While few accidents are reported to have occurred at this location, this intersection has some major deficiencies from a design standpoint. The following lists observed problems:

1. The intersection at Merrimac Square is extremely wide, causing confusion for drivers unfamiliar with the area, and presenting potential traffic hazards. This exceptional width encourages increased speed, passing in the intersection, formation of two driving lanes, and perpendicular parking where only parallel parking is permitted. It also contributes to an overall lack of definition of parking, turning and travelling lanes. The expanse of asphalt should be narrowed and better delineated.

2. The existing island in the center of the square does not adequately control turning motions or direct traffic. A driver, unfamiliar with the area, is confused upon approaching the Square as to which way to turn. The island should be widened and better marked to facilitate traffic flow through the square.

3. Varying widths of roadway on Route 110 fail to encourage a smooth transition of traffic through the square.

4. Existing on-street perpendicular parking in front of Joubert's Pharmacy, the Little and Larkin Block, and School street presents a traffic hazard. Cars backing out of parking spaces in all directions interfere with ongoing through traffic. Perpendicular parking is particularly problemmatic on School street, where the roadway is not wide enough to accomnodate it. Large cars, angle parked here, extend into the street, forcing south bound vehicles to the north bound lane. Perpendicular parking should be eliminated at these locations.

5. Turning motions onto Route 110 are greatly inhibited by parking allowed too near the intersections, as well as the hill and bend in the road at the square. Drivers making a left turn 
onto Route 110 must pull out into the middle of Route 110 in order to see well enough to make the turn. Sight distance and visibility is extremely poor, posing a potential traffic conflict. Proper design treatment could help ameliorate this problem.

6. In the past few years, Church Street has become more frequently travelied. As traffic volumes increase with new development in the northern part of Merrimac, a traffic light may be needed at the intersection of Church Street and Route 110. At present, a hazardous situation exists here, as drivers entering the square are not warned that they are crossing another major roadway. Therefore, motorists tend to proceed without slowing down and without caution. A stop sign is warranted at minimu.

Parking

The results of the Shopper's Survey, designed and conducted by the Author as part of this study, indicated that parking, as perceived by downtown users, was not a major problem. (See Appendix B.) of those interviewed, 75 percent stated that they did not have a difficult time finding downtown parking spaces. However, the merchants in the Square generally disagreed with this assessment, as a majority felt that existing parking was inadequate. An analysis of the parking situation in Merrimac Square is provided to assess the availability and adequacy of parking, and determine whether problems do in fact exist.

Within Merrimac Square, there is a total availability of 307 parking spaces. Approximately one-fourth (24 percent) of parking is on public streets and three-quarters (76 percent) is located in off-street parking lots. Some 76 spaces or 63 percent of the above off-street parking is privately owned and used in conjunction with existing businesses. The 
remaining 82 spaces are within lots which are available for public parking (see Map 9). The Town of Merrimac does not own any municipal parking lots. However, through agreements with private property owners, the land behind the Town Hall and Baptist Church are reserved for municipal parking. Existing parking/floor area ratios were compared with standards established by the Institute of Traffic Engineers ${ }^{32}$ to ascertain whether a surplus or deficit of parking exists. The results are produced in Table 9.

\section{Table 9. PEAK HOUR PARKING DEMAND VERSUS SUPPLY MERRIMAC SQUARE}

\begin{tabular}{|c|c|c|c|}
\hline USE & $\begin{array}{l}\text { EXISTING } \\
\text { FLOOR } \\
\text { SPACE } \\
\end{array}$ & $\begin{array}{l}\text { SPACES NEEDED PER } \\
1000 \text { SQUARE FEET } \\
\text { OF FLOOR SPACE* }\end{array}$ & $\begin{array}{l}\text { PARKING } \\
\text { REQUIRED } \\
\end{array}$ \\
\hline Retail/Services & $\begin{array}{l}19,796 \\
\text { Sq. Ft. }\end{array}$ & 5.0 & 99 \\
\hline Office/Banks & $\begin{array}{l}17,836 \\
\text { Sq. Ft. }\end{array}$ & 3.3 & 59 \\
\hline Municipal & $\begin{array}{l}10,688 \\
\text { Sq. Ft. }\end{array}$ & 3.3 & $\frac{35}{193}$ \\
\hline
\end{tabular}

*From: Institute of Traffic Engineers, Transportation and Traffic Engineering Handbook.

Table 9 shows that only 193 spaces are needed for commercial and municipal uses in Merrimac Square. At present there is a surplus of 114 spaces. Clearly the amount of available parking is not a problem at this time. In fact if one subtracts the 45 spaces, which will be used by the Wolverine Corporation, a net 68 spaces could accomodate an additional 
13,600 square feet of retail space of 20,606 feet of office space in Merrimac Square, without the need to develop additional parking facilities.

The underutilization of parking was further confirmed by a parking survey conducted on a typical business day. An inventory of parked cars was made at five times during the day (9:00 a.m., 11:00 a.m., 1:00 p.m., 3:00 p.m. and 5:00 p.m.). The results of this survey are recorded in Appendix C. During each time period, parking was underutilized. Even during peak hours (between 9:00-11:00) parking spaces were less than 50 percent occupied. This study showed that generally, on-street parking, in front of stores and businesses, received much greater use than private off-street parking lots. The municipal lot behind Town Hall was used to only 50 percent capacity and the Baptist Church lot was used at 10 percent capacity or less.

While the actual number of parking spaces is not a major concern, the parking situation in Merrimac, with regard to design accessibility and enforcement, is problemmatic. On-street parking is unplanned, haphazard and incomprehensible, due to the absence of signs, lines or stripes indicating the type, location or limits of parking. This situation creates much confusion to the outsider visiting the Square and encourages an overall incoherent pattern of parking. To the outsider it is unclear as to whether parking spaces are meant for parallel, angle, or perpendicular parking, or whether parking is allowed at all. Cars were observed 
parked in front of hydrants, on crosswalks and too close to intersections, restricting the sight distance and visibility of motorists attempting to make turns. Existing parking interferes with loading operations and through traffic. Cars backing out of perpendicular spaces in front of the Little Block and Joubert's Pharmacy create an especially troublesome problem.

Enforcement of parking regulations is another problem. Although there are one-hour parking signs in the Square, they are unenforceable because the town has failed to incorporate restrictions in its general ordinances or set up a parking enforcement program. As a result, signs are ignored and all-day parkers occupy prime convenience parking space. Insufficient identification of parking is another problem. Only frequent users of Nerrimac Square are aware that municipal parking exists because of a lack of signs directing the motorist to these lots, and the absence of markers indicating their availability for general use.

A final problem is the physical design and condition of municipal parking areas, which are devoid of landscaping and in need of proper grading and paving. At present, these lots contain no striping or articulation of parking lanes or spaces.

Public Transportation

Merrimac Square is presently unserved by any type of public transportation or taxi. The Merrimack Valley Regional Transit Authority, which provides service within the Haverhil 
CIRCULATION/PARKING

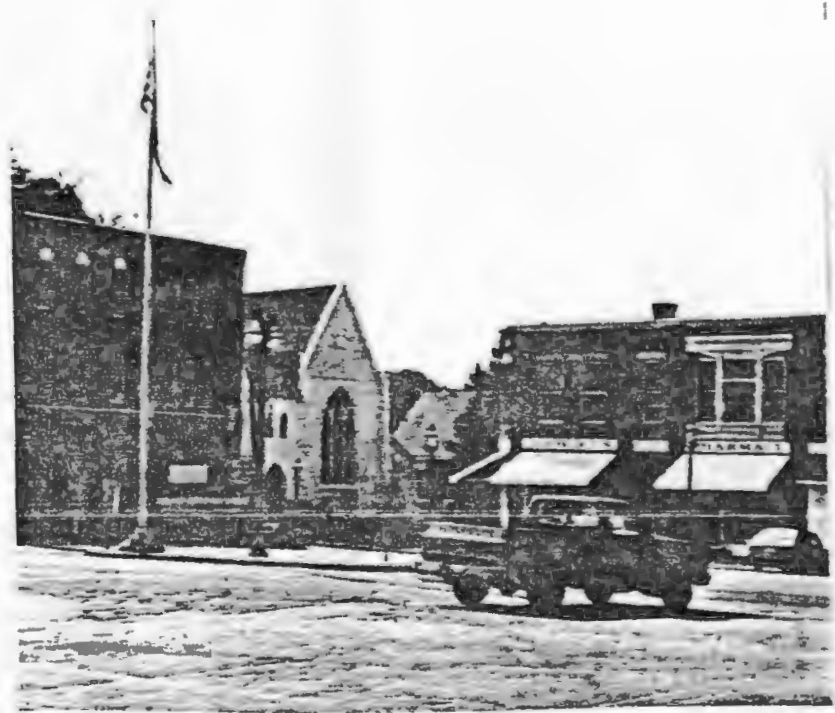

Traffic island is confusing and improperly designed.

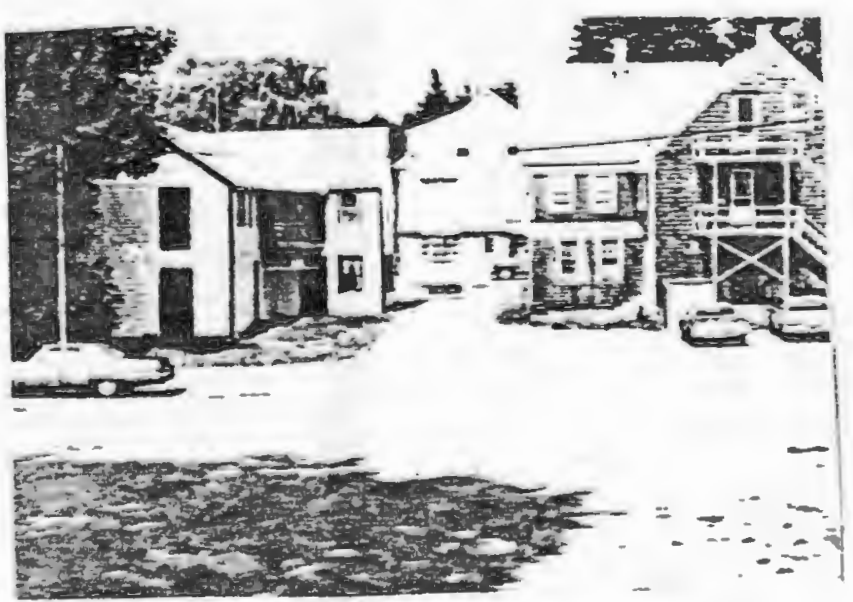

Designated municipal lots in state of disrepair.

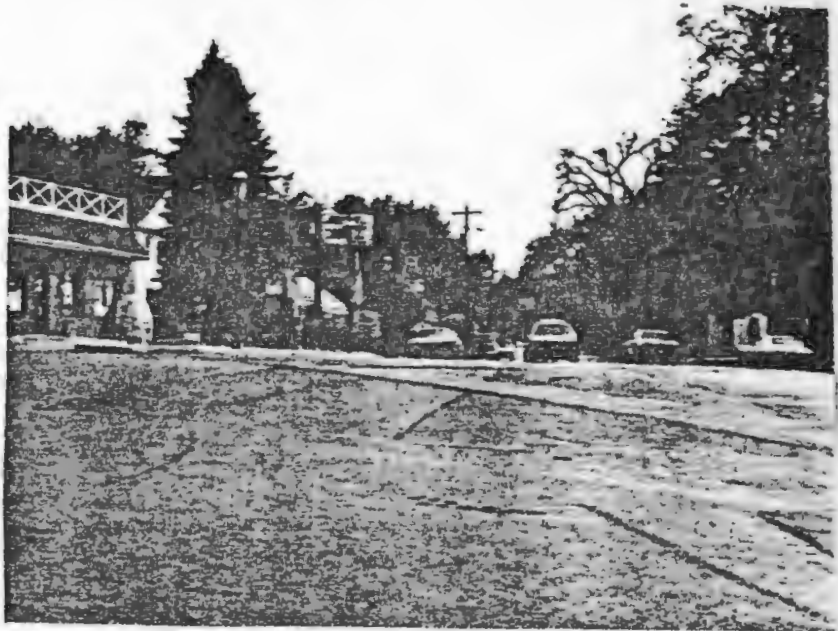

Wide expanse of pavement presents traffic hazards.
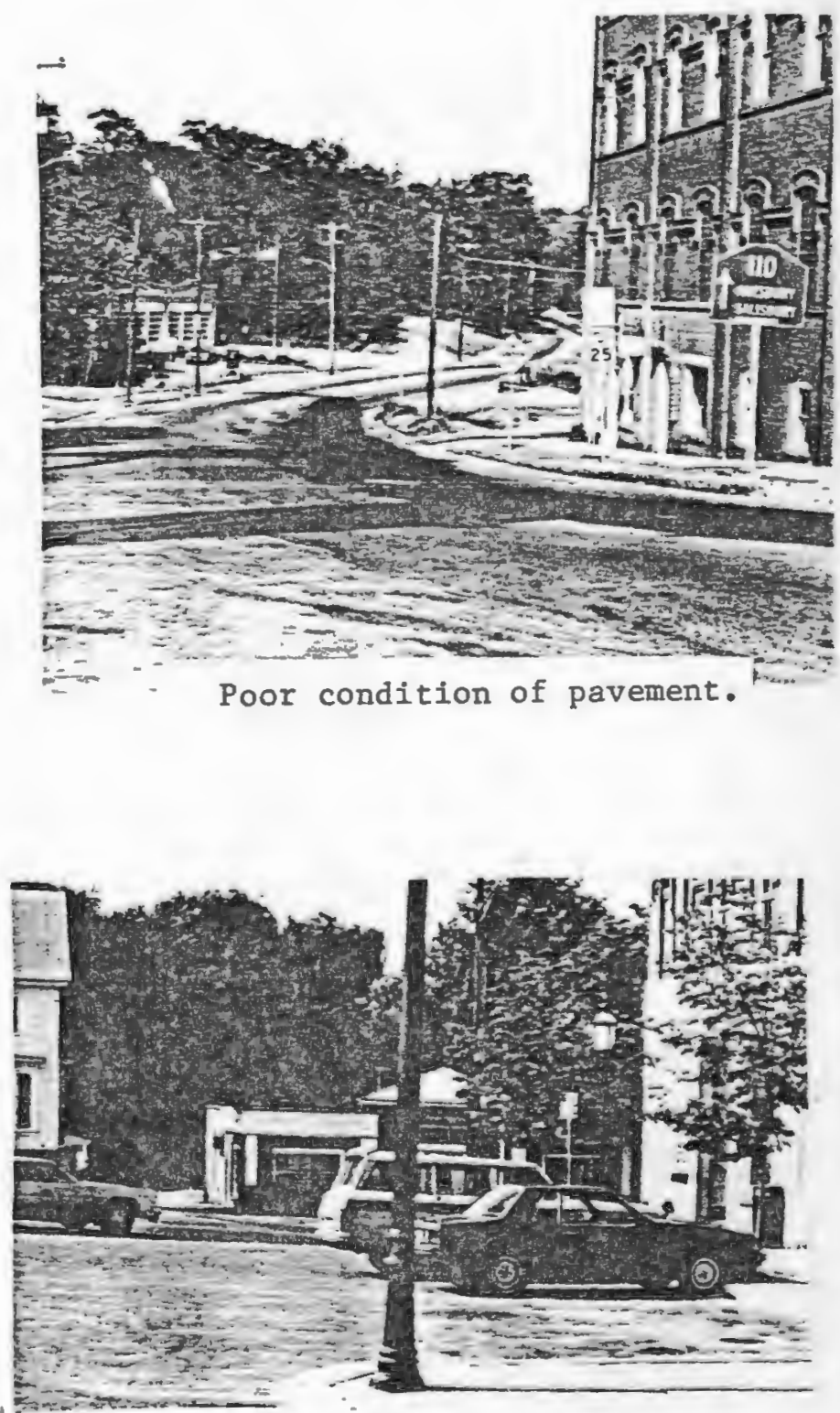

Perpendicular parking, interferes with flow of traffic. 
Area has bus routes which extend only to the Merrimac Town Line.

A proposal to provide bus service to the town on a contractual basis, through the Regional Transit Authority, has been made by the Merrimack Valley Planning Commission. It has not been implemented to date due to the high local subsidy required ${ }^{33}$. A recent effort by the community Action Program and the Council on Aging to provide van service to the needy was attempted but failed due to budget cutbacks and lack of staffing.

Since demands for public transportation are certain to grow in the future ${ }^{34}$, alternative strategies to provide some form of service should continue to be explored.

Economic Analysis

This section studies the economic conditions of Merrimac Square in detail, and assesses its performance as a commercial center. It identifies specific comercial problems experienced by the business sector located there and measures the market potential of the Square today and in the future. A variety of data sources and methodologies have been employed in this analysis, including a review of town records, personal interviews with business people, collection of secondary employment data and market analysis techniques.

\section{An Assessment of Existing Conditions}

Within the Merrimac Square study area there is almost 224,000 square feet of building space. Some 122,657 square feet, or roughly 55 percent, is located on the first floor 
of buildings, while 102,031 square feet is found on upper floors.

Table 10 provides a breakdown of building space by occupancy. Institutional uses comprise the largest occupancy

Table 10. MERRIMAC SQUARE - OCCUPANCY OF BUILDING AREA

FIRST FLOOR OTHER FLOORS TOTAL SQ. FT. \% OF TOT. SQ. FT. \% OF TOT。 SQ. FT. \% OF TOT.

\begin{tabular}{|c|c|c|c|c|c|c|}
\hline Retail/Services & 19,796 & 16.0 & 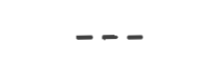 & $\cdots$ & 19,796 & 9.0 \\
\hline Offices/Banks & 11,234 & 9.0 & 6,602 & 6.0 & 17,836 & 8.0 \\
\hline Restaurants & 2,302 & 2.0 & -- & -- & 2,302 & 1.0 \\
\hline Residential & 18,843 & 16.0 & 34,549 & 34.0 & 54,392 & 24.0 \\
\hline Institutional & 42,674 & 35.0 & 25,141 & 25.0 & 67,815 & 30.0 \\
\hline Manufacturing & 22,496 & 18.0 & 28,339 & 27.0 & 50,836 & 23.0 \\
\hline Vacant & 4,312 & 4.0 & 7,400 & 7.0 & 11,712 & 5.0 \\
\hline TOTAI & 122,657 & $(55.0)$ & 102,031 & $(45.0)$ & 224,688 & \\
\hline
\end{tabular}

category, while restaurants make up the smallest category. Retail and service uses include nine percent of 19,796 square feet of the floor area within downtown. Banks and miscellaneous office space occupies 17,836 square feet of floor area. This analysis shows that five percent of the total floor area of Merrimac Square is vacant. A little more than a third of this space is located on first floors and two-thirds in upper stories. In addition to the existing vacant space, a good amount of floor area within these structures is under- 
utilized. For example, the Grange Hall, American Legion Hall and the third floor meeting hall in the Merrimac Savings Bank are, at most, utilized only two or three times a month, and left virtually empty the remainder of the time. These spaces could be put to a more economically viable use if rehabilitated and properly marketed.

Some floor area is also being occupied by residential uses which do not represent "the highest and best use" of this space. The house located next to the liquor store and post office, is another prime site for commercial development which, at present, is underurilized from an economic point of view.

In total, some 31,039 square feet of floor is underutilized in Merrimac Square. Roughly one-third: (8,037 square feet)-is first floor space suitable for retail, restaurant, office or other similar uses. Combined, vacant and underutilized space comprises more than 20 percent of the total floor area available in the square.

Map 10 illustrates the location of vacant and underutilized floor space in Merrimac Square.

Economic Situation

Figures obtained from the Massachusetts Division of Employment Security show that the number of establishments engaged in wholesale and retail trade has increased from 19 in 1971 to 21 in 1979. Employment in these sectors grew from 93 to 100 during this same period ${ }^{35}$. 


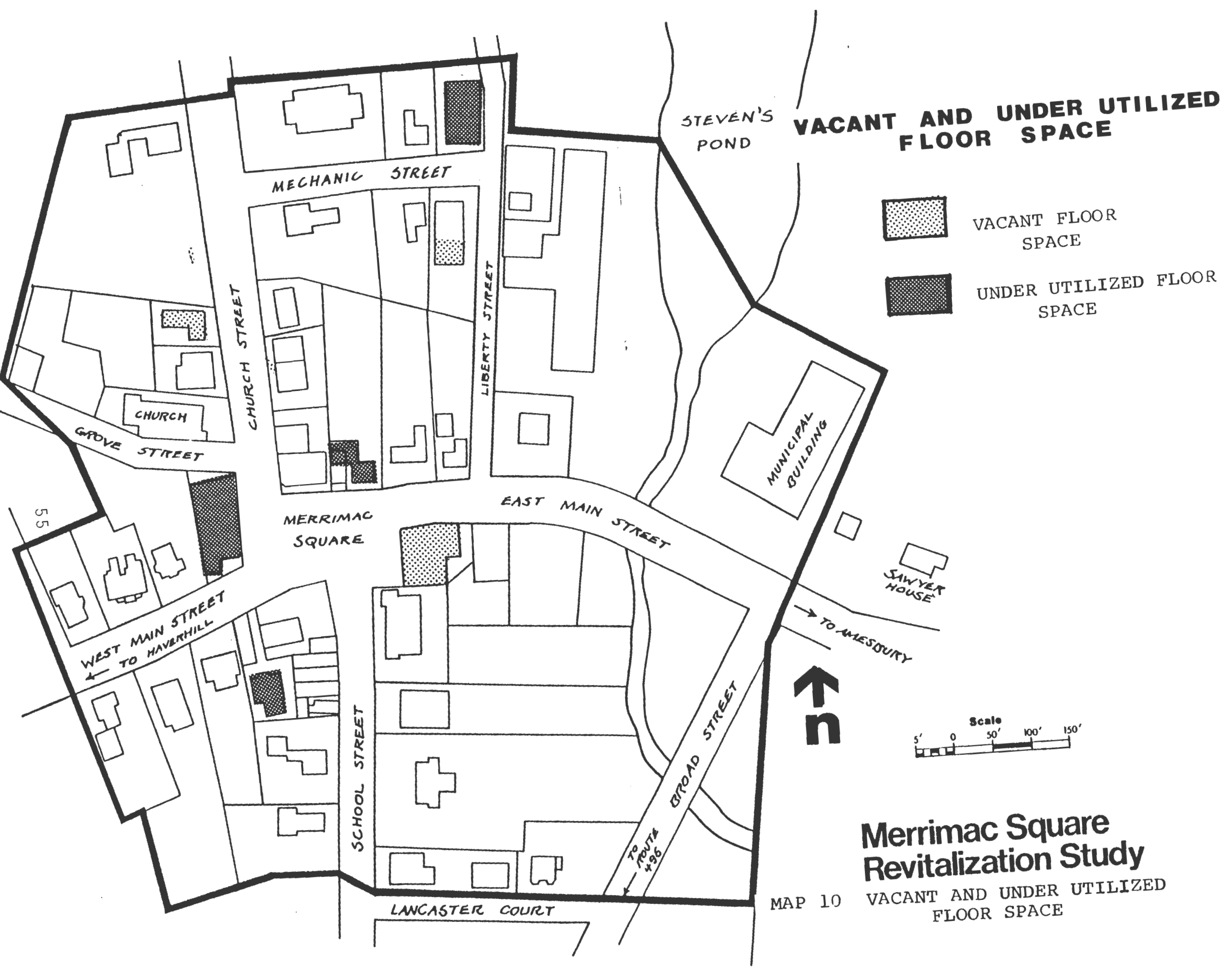


Despite this apparent growth in retail trade, economic conditions in Merrimac Square have been less than stable. During the past ten years, there has been a considerable amount of business turnover. It is estimated that more than 18 businesses came and went during this period ${ }^{36}$. This high rate of turnover is significant considering there are only 19 businesses presently in the downtown.

The above problems are not unique to Merrimac. Square and are largely attributable to increased competition from suburban shopping centers.

The 1950's and 1960's brought significant commercial development to the Merrimak Valley Region in the form of shopping centers and strip development. Comercial developments affecting Merrimac were constructed in the adjacent Cities of Haverhill and Amesbury.

The newer shopping centers, with their ample parking and pleasant environment, became an "attractive" alternative to the older obsolete central business districts. Many merchants, in response to increased competition, chose to move from downtown locations to pursue business in more profitable locations in shopping centers or along arterial highways. For those who remained, the realities of economic decline became evident. As their sales volumes declined, so did their ability to assume high overhead and invest in the upkeep of their properties, causing comercial disinvestment and resulting physical deterioration.

While the decline of Merrimac's Central Business District has not been as severe as in the larger Cities 
of Haverhill or Lawrence, signs of commercial disinvestment and economic instability are visible today. A high ratio of vacant and underutilized space and rapid turnover of businesses has already been mentioned. Another concern is the lack of capital investment in the center. Although a considerable number of land sales have taken place over the past five years, only one major expansion project of more than $\$ 10,000$ has occurred and no new development has taken place. A review of building permit activity in the Square between 1975 and 1976 shows only 13 permits were issued during this period (see Appendix D). This amounted to only $\$ 30,000$, generating a mere $\$ 900$ in tax revenue ${ }^{37}$.

The physical condition of existing commercial structures is also indicative of economic instability. While most are structurally sound, 45 percent were rated as being in poor or fair condition in the building survey. Merchants Survey

A survey was administered to local merchants in Merrimac Square to obtain information regarding tenure, customer service areas, rents, business plans, sales volume and merchant perceptions of the assets and problems of the Square (a copy of this survey is included as Appendix E). A total of 12 merchants responded to the survey, representing an 80 percent sample. Merrimac Square's small size permitted personal interviews with local merchants, accounting for the high repsonse rate.

of those surveyed, half owned and half rented their comercial space. 
Rents varied according to the location, physical condition of tenant space, and use. Rents ranged from $\$ 1.21$ per square foot to $\$ 8.00$ per square foot, rates which are generally lower than those found in suburban shopping centers. One-third of the merchants surveyed had located in the square within the preceding five-year period, while 40 percent were long-time occupants of ten years or more. The merchants estimated a total of 900 customers per day and believed that 80 percent of their customers were Merrimac residents. These figures are consistent with the results of the shopper's survey and support the finding that the Square's primary market area is the Town of Merrimac.

Most of the merchants indicated they employed between one and four employees. One business employed up to nine employees. Overall, retail uses in the downtown do not provide large-scale employment. Total retail employment is approximately 22 persons.

Retail sales data for Merrimac Square is unavailable through secondary data sources. Survey questions concerning sales volume were used to assess business performance in the study area. Merchants seemed hesitant about answering the question and some refused to respond. Of the only eight merchants who answered, two indicated that sales volume had declined, four responded that volume had increased and two felt business had remained stable.

When asked about their future business plans, ten merchants indicated no intent to change their existing space, one expressed plans to leave the downtown area and one 
mentioned plans for a major expansion. Cost was estimated in excess of $\$ 10,000$, involving the construction of an additional 13,000 square feet of retail space.

The positive features of the Square, from the merchants perspective, include its prime location at the cross roads of major streets, its convenience, layout, picturesque atmosphere and orientation to the family.

There was little consensus among the merchants regarding the major problems of the Square. Inadequate parking, vandalism and loitering were viewed by half those surveyed as being a major concern. One-third cited their inability to attract new customers as a negative feature. No merchant considered zoning to be an obstacle. Only one mentioned inadequate space for expansion and lack of public investment as a business problem. Other concerns mentioned were the lack of maintenance of town plantings, competition from malls, and the need for a "magnet" grocery store to attract new customers to the area.

Seven merchants felt parking improvements were necessary and five expressed interest in a storefront rehabilitation program. Four agreed street and sidewalk improvements and public transportation were necessary. Only two indicated the need for traffic improvements and one believed coordinated signs and facades would enhance the area.

The business sector was able to provide several helpful suggestions for improving Merrimac Square. Suggestions included the addition of benches and parking signs, installation of a flashing yellow light at the intersection, more 
police patrols and enforcement of parking signs, rubbisi collection and maintenance of plantings.

Merchants expressed overwhelming support for the establishment of a business group to help tackle some of these problems. Three quarters of the respondents expressed interest in forming such an organization. Market Analysis

Part of the success of any downtown revitalization program depends upon the ability of the community to attract new development and encourage business expansion within the downtown. New development and expansion provides many benefits to the comunity in the form of new jobs, increased tax revenue and the physical upgrading of the area. Indirect benefits are also offered. Increased downtown employment creates additional purchasing power. New employees will tend to patronize local stores and restaurants during lunch time hours and after work thereby increasing downtown business. Also, new development acts as a catalyst for further growth and creates a chain reaction among merchants and land owners to upgrade their properties. Increased competition encourages the owners of older structures to renovate and modernize in order to retain existing tenants 38 .

It should be kept in mind, however, that the best conceived revitalization plan to promote new development in the Central Business District can fail in the atsence of adequate market demand for that development. Therefore, it is essential to perform a market analysis in order to assess the market potential for additional retail and office 
space in Merrimac Square. The narket analysis can be used to develop plans for providing additional stores, expanding existing ones or attract new businesses to the downtown ${ }^{39}$.

\section{Methodology}

The technique used in assessing the market potential of Merrimac Square is that found in the Downtown Improvement Manual, published by the American Society of Planning Officials.

The first step undertaken in the market study was the determination of the trade area. According to above-mentioned source, a trade area is defined as "that area from which downtown retail establishments can expect to receive 80 to 90 percent of their businesses" 40 . The trade area is determined by a number of factors including, the distance shoppers are willing to travel to make certain purchases on a daily or weekly basis, the location of other commercial centers, the type and size of the center, physical barriers, (rivers, lakes) and the population patterns of the area. While. definition of a trade area is largely a judgemental matter, a number of rules of thumb can be used.

Merrimac Square functions as a convenience goods center because its retail facilities offer merchandise (such as food and drug store items) which is purchased frequently. Typically, shoppers will not travel long distances to purchase these goods. According to the Shopping Center Development Handbook, a center of the 


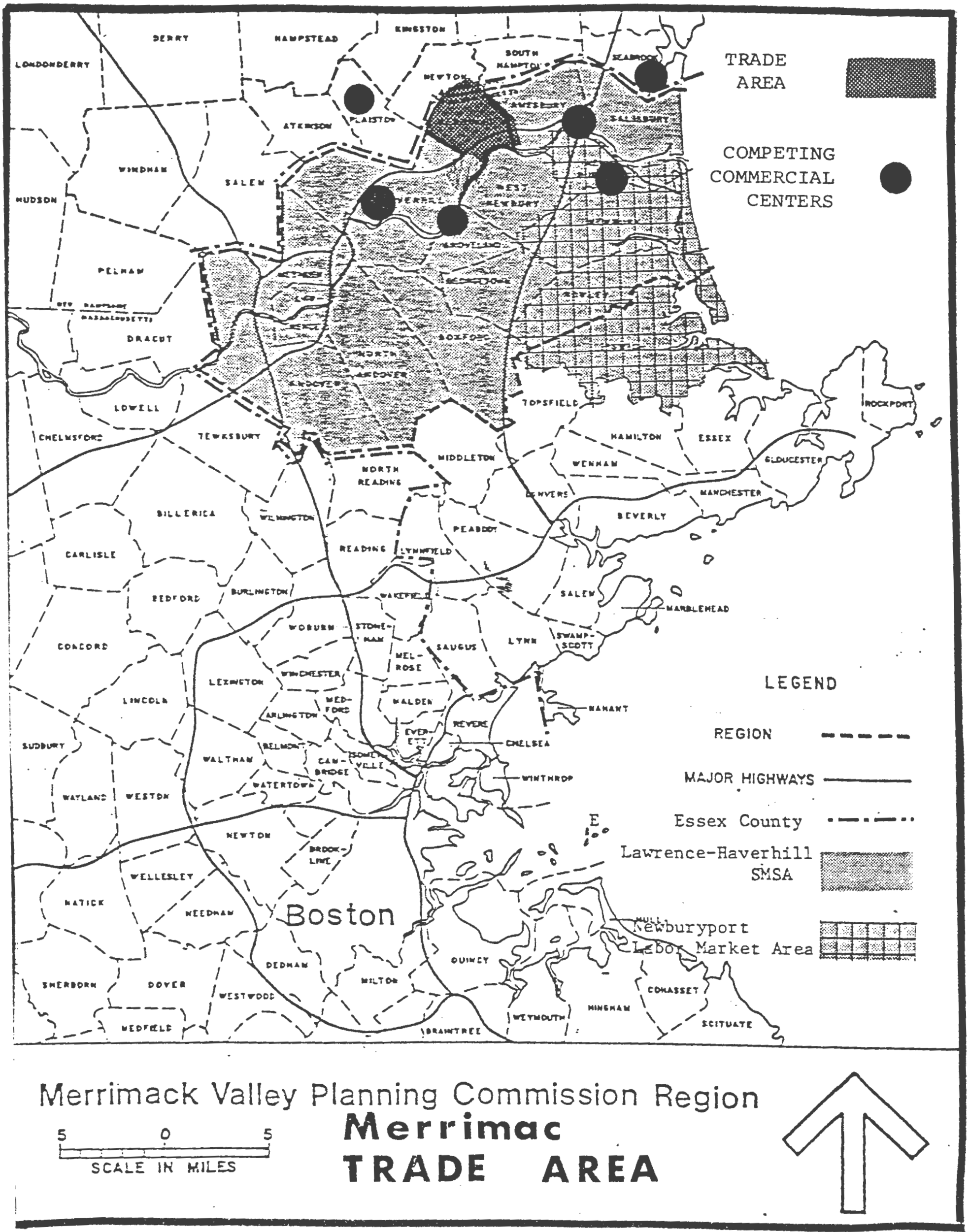


type and size of Merrimac draws shoppers from a radius of one to two and one-half miles and serves a population of 3,500 to $5,000^{41}$.

The boundaries of the trade area can be approximated by drawing a two and one-half mile radius around Merrimac Square and approximating the population residing within the boundaries of the circle. (See Map 11.) It was found that the trade area boundaries closely conform with the town boundaries. Therefore, it can be reasonably assumed that the trade area served by Merrimac Square is the Town of Merrimac. This assumption is further supported by the lack of competing centers in this zone, and the results of the Merchants and Shoppers Surveys which follow. In these surveys, merchants indicated that 80 percent of their customers were Merrimac residents, while nearly 85 percent of the shoppers interviewed indicated they lived in Merrimac. These findings are consistent with definitions of a trade area as presented above.

Having determined the boundaries of the trade area, the next step involved the estimation of Merrimac's existing and future retail sales potential. First, ratios of retail sales per capita were established using data from the 1977 Census of Retail Trade and the 1980 Census of Population ${ }^{42}$. Since Merrimac Square functions as a convenience center, as discussed previously, retail sales per capita figures were provided for the following types of stores: food, drugs, hardware 
and liquor, as shown in Table 11.

Table 11. RETAIL SALES PER CAPITA - LAWRENCE-HAVERHILL SMSA

RETAIL SALES
(IN THOUSANDS)

Food Store

$\$ 217,196$

$\$ 756.78$

Drugs

26,321

91.71

Hardware

7,898

27.52

Liquor

24,816

86.46

NOTE: Population of Lawrence-Haverhill SMSA is estimated at 287,000 in 1977 .

Source: U. S. Department of Commerce, Bureau of Census, Census of Retail Trade, 1977. Merrimack Valley Planning Commission, 1980.

-. Second, per capita retail sales in the LawrenceHaverhill SMSA were adjusted to account for the difference in income between the SMSA average and the Town of Merrimac. The 1070 Census of Population showed Merrimac's median income total to be 93 percent of the SMSA's. It was therefore assumed that retail sales per capita in Merrimac were 93 percent of the SMSA average, as indicated in Table 12.

Third, retail sales per capita projections were made for the years 1980, 1985, 1990 and 1995. Assuming that convenience goods increase by 1.5 percent per annum, future retail sales per capita figures were derived (Table 13). These ratios were then applied to population projections for 1980, 1985, 1990 and 1995, as forecasted earlier in the report (see Table 5), to 
Table 12. ESTIMATION OF RETAIL SALES PER CAPITA - TOWN OF MERRIMAC: 1977

$\begin{array}{lr}\text { Foods } & \$ 708.35 \\ \text { Drugs } & 85.84 \\ \text { Hardware } & 25.76 \\ \text { Liquor } & 80.90\end{array}$

*Accounts for income discrepancy between SMSA and Town.

Table 13. PROJECTION OF RETAIL SAIES PER CAPITA TOWN OF MERRIMAC* - 1980-1995

FOOD STORES DRUG STORES HARDWARE STORES IIQUOR STEES

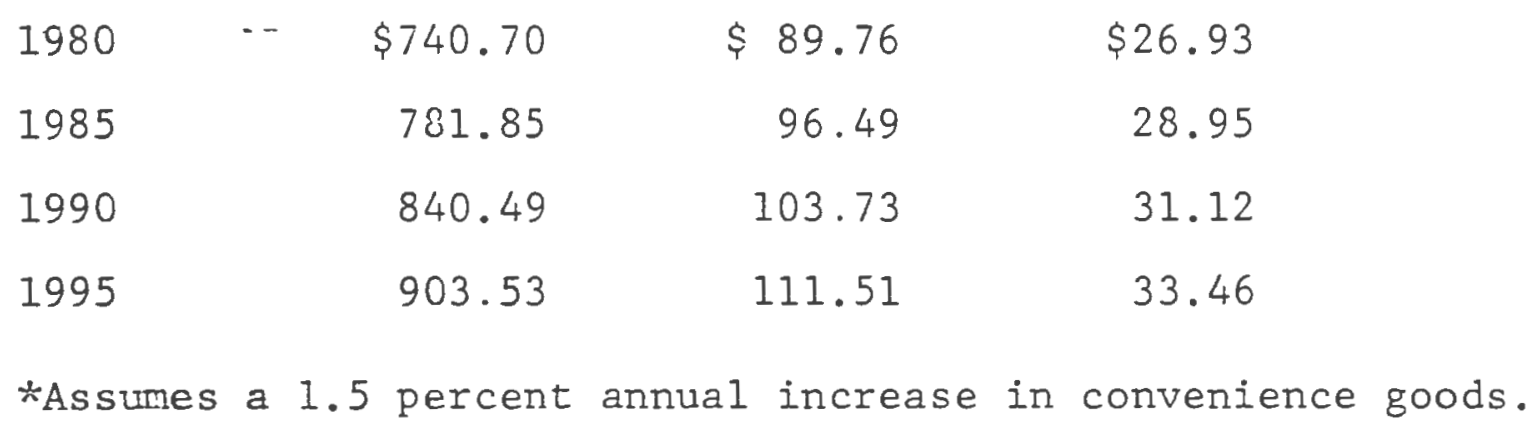

yield total retail sales potential. As Merrimac Square could not be projected to capture this entire sales potential, these projections were adjusted by a 85 percent capture ratio 43 . The results are produced in Table 14. 


\section{Table 14. PROJECTED RETAIL SALES (IN THOUSANDS) - MERRIMAC* $\underline{1980-19.95}$}

\begin{tabular}{lcccc} 
YEAR & FOOD STORES & DRUG STORES & HARDWARE STORES & LIQUOR STORES \\
1980 & $\$ 2,802$ & $\$ 339$ & $\$ 101$ & $\$ 320$ \\
1985 & 3,031 & 374 & 112 & 353 \\
1990 & 3,340 & 412 & 123 & 388 \\
1995 & 3,680 & 454 & 136 & 428 \\
\multirow{2}{*}{ *Assuming an 85 percent capture ratio. } &
\end{tabular}

Retail sales potentials were then translated into square footage estimates based on retail sale/square foot ratios provided by the Dollars and Cents of Shopping -Genters Handbook ${ }^{44}$. (See Table 15.) The demand for additional retail space was determined by subtracting the existing supply of retail area from the total supportable square footage. Results are shown in Table 16.

Table 15. NATIONAL MEDIAN ANNUAL SALES VOLUME PER SQUARE FOOT OF GROSS LEASABLE FLOOR AREA (FOR COMTUNITY CENTERS) 1975

$\begin{array}{llr}\text { Food Store } & - & \$ 135.22 \\ \text { Drug Store } & - & 78.95 \\ \text { Hardware Store } & - & 44.09 \\ \text { Liquor and Wines } & - & 121.86\end{array}$

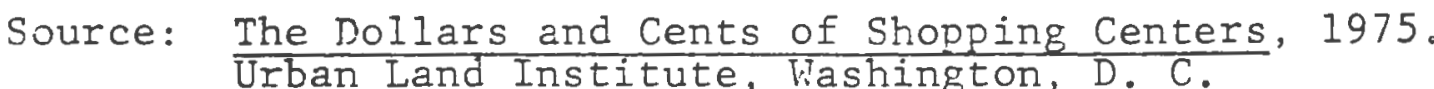


Table 16. FUTURE DEMAND FOR CONVENIENCE RETAIL SPACE (IN SQUARE FEET) MERRIMAC SQUARE - 1980-1995

YEAR FOOD STORE DRUG STORE HARDIARE STORE IIQUOR STORE

$1980 \quad 13,200 \quad 1,700$

$1985 \quad 14,900 \quad 2,100$

$1990 \quad 17,200 \quad 2,600$

$1995 \quad 19,700$

3,100

$-\cdots$

$300+$

A similar analysis was done to estimate future demand for office space. The relationship between employment growth (in various sectors of the economy) and population growth was established and used to project employment in 1980, 1985, 1990 and 1995. Typical space requirements per employee were applied to derive office space demand ${ }^{45}$. The results are recorded in Table 17.

Table 17. FUTURE DEMAND FOR OFFICE SPACE

1. Employment Change (1967-1977)

Business Service $\quad+53$

Source: Comonwealth of Massachusetts, Division of Employment Security - Employment and Wages by Cities and Towns - 1967-1978.

2. Population Change (1967-1977)

$$
\begin{aligned}
& 1967-3,49 \\
& 1977-4,389 \quad \text { Net Change: }+439
\end{aligned}
$$

Source: City and Town Monograph, Town of Merrimac. 
Table 17. FUTURE DEMAND FOR OFFICE SPACE (CONTINUED)

3. Employment Change/Population Change

$$
53 / 439=.12
$$

4. Population Projections (From Table 5)

$\begin{array}{llrrrr}\text { 5. Future Population Change } & +62 & +173 & +287 & +403 \\ \text { 6. Employment Growth } & 7 & 34 & 62 & 91\end{array}$

$\begin{array}{rrrr}\frac{1980}{4,451} & \frac{1985}{4,562} & \frac{1990}{4,676} & \frac{1995}{4,792} \\ +62 & +173 & +287 & +403 \\ 7 & 34 & 62 & 91\end{array}$

(Population Change $X .12$ )

7. Office Space Demand $\quad 1,120 \quad 3,360 \quad 5,540 \quad 7,680$ sq. ft. sq. ft. sq. ft. sq. ft.

(Employment X 1 employee per 160 square feet)

Source: Downtown Improvement Manual, Emanuel Bark, 1976.

Findings

1. At present, there is a market demand for an additional 13,200 square feet of food store space. This could involve the expansion of an existing grocery store, perhaps to accommodate a meat or fresh vegetable section. A new medium-sized modern supermarket could be supported in Merrimac Square by the year 1995.

2. The study revealed that an additional 1,700 square feet of drug store space could be supported in the Square at this time. It is estimated that by 1990 , a new drug store could feasibly be opened in the square.

3. At this time, there is little or no demand for more hardware store space. In all likelihood, support will continue to be lacking well into the 1990's.

4. The study indicates no present or future demand for additional liquor store space until 1995. 
5. Local employment in the finance, real estate and insurance sector declined between 1967 and 1977, indicating little market demand for office space by this sector.

6. The office space market study shows moderate employment growth in the general business services sector. At present, there is a market support for an additional 1,120 square feet of general office space in Merrimac. This figure should increase to 7,680 square feet by 1995 .

Shopper's Survey

A shopper's survey was conducted to obtain information on consumer attitudes and buying behavior, and to help identify the strengths and weaknesses of Merrimac Square from the perspective of those who use it.

While a number of survey modes were considered in gathering this information, it was decided that personal interviews with downtown users would be the most effective and least time-consuming method. The major drawback with this approach is that it does not include the opinions of those who do not shop in the Square, thus introducing the possibility of bias. It should be stressed that this survey is not meant to be statistically representative of the attitudes of Merrimac residents. Its purpose is merely to provide information.

The survey was designed to include objective questions which would provide a profile of the "typical" Merrimac shopper. Subjective questions were asked to allow the interviewer the opportunity to evaluate goods, services and existing conditions regarding parking, traffic and aesthetics; and to offer solutions to perceived problems. A variety of question formats were employed including multiple choice, ordinal scales and open-ended 
responses. (A copy of this survey is included as Appendix B.)

The survey was conducted on Friday, July 17, 1980, a clear day with temperatures in the mid-eighties. Two interviewers randomly roamed Merrimac Square's streets and stores in search of possible respondents. The survey was administered in shifts, between 9:00 a.m. and 7:00 p.m., to insure that a reasonable cross section of shoppers was included in the survey. A total of 48 downtown users were interviewed. The following outlines the results:

1. Sex of respondent:

Male $\quad 35$ percent

Female 64 percent

2. Age of respondent:

$\begin{array}{rr}16-23 \text { years } & 8 \text { percent } \\ 23-35 \text { years } & 33 \text { percent } \\ 35-50 \text { years } & 23 \text { percent } \\ -50-65 \text { years } & 25 \text { percent } \\ 65+\text { years } & 10 \text { percent }\end{array}$

3. Residency of respondent:

Merrimac 79 percent

Elsewhere 21 percent

4. Length of residency in Merrimac:

$0-3$ years 18 percent

4-10 years 16 percent

10-20 years 24 percent

$20+$ years 42 percent

5. Reason for coming to downtown:

$\begin{array}{lr}\text { Work } & 18 \text { percent } \\ \text { Shop } & 23 \text { percent } \\ \text { Services } & 40 \text { percent } \\ \text { Restaurant } & 15 \text { percent } \\ \text { Municipal Business } & 4 \text { percent }\end{array}$

6. Frequency of visits to downtown:

More than once a week

Once a week

Once a month

Less than once a month
91 percent

6 percent

3 percent

1 percent 
7. Shops or services which are necessary (number of responses):

$\begin{array}{lrll}\text { Discount } & 5 & \text { Jewelry } & 1 \\ \text { Restaurant } & 13 & \text { Shoe Repair } & 8 \\ \text { Shoes } & 3 & \text { Dentist } & 2 \\ \text { Doctor } & 10 & \text { Theatre } & 3 \\ \text { Clothing } & 11 & \text { Pinball Arcade } & 1 \\ \text { Grocery } & 13 & \text { Ice Cream } & 1 \\ \text { Florist } & 3 & \text { Books } & 3 \\ \text { Gas Station } & 2 & \text { Hobby } & 1 \\ \text { Bakery } & 1 & \text { Auto Parts } & 1 \\ 5 \text { \& } 10 & 3 & & \end{array}$

8. Location of routing shopping:

$\begin{array}{lr}\text { Amesbury } & 27 \text { percent } \\ \text { Haverhill } & 27 \text { percent } \\ \text { Seabrook } & 27 \text { percent } \\ \text { Newburyport } & 4 \text { percent } \\ \text { W. Newbury } & 4 \text { percent } \\ \text { Plaistow } & 7 \text { percent } \\ \text { Other } & 4 \text { percent }\end{array}$

9. Evaluation of goods and services:

\begin{tabular}{|c|c|c|c|c|}
\hline & Excellent & Good & Fair & Poor \\
\hline Quality & $23 \%$ & $66 \%$ & $10 \%$ & $0 \%$ \\
\hline Selection & $10 \%$ & $41 \%$ & $37 \%$ & $10 \%$ \\
\hline Prices & $4 \%$ & $25 \%$ & $54 \%$ & $16 \%$ \\
\hline
\end{tabular}

10. A. I can always find a place to park in Merrimac Square:

$\begin{array}{lr}\text { Strongly Agree } & 25 \text { percent } \\ \text { Agree } & 50 \text { percent } \\ \text { Disagree } & 17 \text { percent } \\ \text { Strongly Disagree } & 0 \text { percent } \\ \text { No Opinion } & 8 \text { percent }\end{array}$

B. Pedestrian safety is a real problem in Merrimac Square:

$\begin{array}{lr}\text { Strongly Agree } & 14 \text { percent } \\ \text { Agree } & 22 \text { percent } \\ \text { Disagree } & 43 \text { percent } \\ \text { Strongly Disagree } & 13 \text { percent } \\ \text { No Opinion } & 4 \text { percent }\end{array}$

C. The buildings in Merrimac Square are badly deteriorated and need rehabilitation:

$\begin{array}{lrl}\text { Strongly Agree } & 4 \text { percent } \\ \text { Agree } & 29 \text { percent } \\ \text { Disagree } & 6 \text { percent } \\ \text { Strongly Disagree } & 54 \text { percent } \\ \text { No Opinion } & 7 \text { percent }\end{array}$


D. Shopping in Merrimac is an enjoyable experience:

$\begin{array}{lrl}\text { Strongly Agree } & 6 \text { percent } \\ \text { Agree } & 48 \text { percent } \\ \text { Disagree } & 29 \text { percent } \\ \text { Strongly Disagree } & 6 \text { percent } \\ \text { No Opinion } & 10 \text { percent }\end{array}$

E. Downtown merchants and salespeople are helpful and courteous:

$\begin{array}{lr}\text { Strongly Agree } & 43 \text { percent } \\ \text { Agree } & 50 \text { percent } \\ \text { Disagree } & 2 \text { percent } \\ \text { Strongly Disagree } & 0 \text { percent } \\ \text { No Opinion } & 4 \text { percent }\end{array}$

F. Public transportation to Merrimac Square is necessary:

$\begin{array}{lr}\text { Strongly Agree } & 11 \text { percent } \\ \text { Agree } & 48 \text { percent } \\ \text { Disagree } & 23 \text { percent } \\ \text { Strongly Disagree } & 6 \text { percent } \\ \text { No Opinion } & 4 \text { percent }\end{array}$

G. The traffic intersection in Merrimac Square is dangerous and should be improved:

$\begin{array}{lr}\text { Strongly Agree } & 27 \text { percent } \\ \text { Agree } & 31 \text { percent } \\ \text { Disagree } & 38 \text { percent } \\ \text { Strongly Disagree } & 4 \text { percent } \\ \text { No Opinion } & 0 \text { percent }\end{array}$

H. Vandalism, noise and loitering are major problems in the Square:

$\begin{array}{lr}\text { Strongly Agree } & 50 \text { percent } \\ \text { Agree } & 40 \text { percent } \\ \text { Disagree } & 2 \text { percent } \\ \text { Strongly Disagree } & 0 \text { percent } \\ \text { No Opinion } & 8 \text { percent }\end{array}$

I. The signs and storefronts in Merrimac Square are uncoordinated, cluttered and unattractive:

$\begin{array}{lr}\text { Strongly Agree } & 4 \text { percent } \\ \text { Agree } & 25 \text { percent } \\ \text { Disagree } & 62 \text { percent } \\ \text { Strongly Disagree } & 8 \text { percent } \\ \text { No Opinion } & 0 \text { percent }\end{array}$


11. Preferences for store hours:

Same as now

Open earlier

Close later

Open nights

open weekends

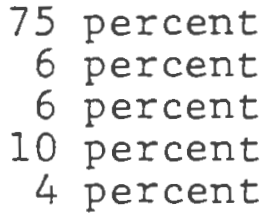

4 percent

12. Other problems and perceptions:

"Teenagers hanging out are a major problem."

"Land across from the fire station is wasted space."

"New lights in Square don't shed enough light. This contributes to the vandalism/loitering problem."

"Drugs, kids, drinking and litter are major problems in the Square."

"I hate Victorian buildings."

"Fix the roads."

"The sooner the sewer construction project is done, the better."

"The intersection is dangerous, especially for children and elderly crossing it."

13. Improvements and/or changes:

"A stop sign is needed at the intersection of Church Street and Main."

"Get rid of the dead elm trees."

"Create a pedestrian-oriented Square. Prohibit automobiles."

"Rid the Square of teenagers at night."

"Keep the Square the same."

"Repair the town clock."

"Install a traffic light in front of the Fire/Police Station."

"Signs and facades should be better coordinated."

"The Legio: Hall should be better utilized."

"The old water trough should be used as a historic resource." 
"A stop light at the Square intersection is necessary."

"Some storefronts in the downtown need a facelift."

"Install handicapped ramps in Merrimac Square."

"Better police protection is necessary to combat the loitering problem."

"More activities for youths are needed."

"Stop teens from loitering."

"Bring back stores to the way they were ten years ago. The older stores had more variety."

"We need a larger rotary."

"The Square should have traffic and directional signs."

"Pave the parking lots."

"A patrolman for downtown is necessary."

"Put back the old street lights."

"I would'like to see improvements similar to those made in Newburyport." $\cdots$

"Better traffic flow."

"Get rid of the pigeons."

14. Responses to questions regarding various proposals:

Parking lot:

in favor of 33 percent opposed to 66 percent

Street improvements:

in favor of 54 percent opposed to 46 percent

Community center:

in favor of 71 percent opposed to 29 percent

Town park:

in favor of 56 percent opposed to 44 percent 
Multi-family housing:

in favor of 21 percent opposed to 78 percent

A historic designation:

in favor of 28 percent opposed to 71 percent

Traffic improvements:

in favor of 73 percent

opposed to 27 percent

Storefront rehabilitation:

in favor of 56 percent opposed to 42 percent

Sign controls:

in favor of 52 percent

opposed to 44 percent

Findings

The shopper's survey revealed several interesting findings. Some served to reinforce preconceived notions of the Square, while others shed new light on its problems.

The survey provided a profile of the "typical" downtown user. The majority of those interviewed were female (64 percent) and between the ages of 23 and 50. A significant number (85 percent) were residents of the Town of Merrimac.

of those interviewed who lived out of town, most were from adjacent towns or were former Merrimac residents. As the nearby Town of Newton, New Hampshire has few stores or services, many Newton residents shop at Merrimac Square.

The survey results indicate that Merrimac Square functions as a convenience goods center. Convenience goods are defined as "goods which are needed immediately and often 
and which are purchased where it is most convenient for the shopper." (Shopping Center Development Handbook, p. 3.$)^{46}$ Included in this category are merchandise such as food, drug store items, liquors and hardware goods. The above assumption is supported by the fact that 62 percent of those surveyed cited shopping or services as the primary reason for visiting downtown Merrimac. It is further confirmed by the finding that 92 percent of the respondents visited the Square more than once per week while 47 percent visited it daily.

of interest is the finding that a great many of the Merrimac residents interviewed ( 66 percent) were long-time residents: of ten years or more. This suggests a strong tendency or commitment of long-time residents to patronize local-stores. It was mentioned by a few that the Square serves the social needs of old-timers, as a place to meet old friends and keep up with local news.

The second part of the survey indicates that generally users are content with the goods and services in the downtown. A total of 89 percent of the respondents indicated that the quality of available goods and services was either good or excellent.

Shoppers were somewhat less satisfied with the variety of selections offered. Only 50 percent felt that variety was good or excellent. Prices of goods and services were rated considerably lower. The majority of those interviewed (70 percent) responded that prices were fair or poor. Only four percent indicated that prices were excellent. 
Most Merrimac Square users were happy with the existing hours of operation of shops and businesses. According to the survey, 75 percent felt no changes were necessary. Only 10 percent of the shoppers interviewed expressed a desire to have some of the stores opened at night. An overwhelming majority of downtown users (93 percent) felt that the merchants and sales people were helpful and courteous .

The survey produced a variety of responses to the question regarding routine shopping. The location of routine shopping depended largely on the residence of the respondent. Amesbury, Haverhill and Seabrook were most frequently cited locations. A considerable number ( 36 percent) indicated that they shopped in New Hampshire to escape Massachusetts sales. taxes.

When shoppers were asked to list types of stores or services they would like to see in Merrimac Square, a total of 83 responses were received. Approximately 16 percent of the responses indicated the desire for a supermarket (the most frequently mentioned choice). A doctor's office and clothing stores were cited as the second greatest need, followed by a good restaurant geared toward evening dining. A shoe repair store was also mentioned several times as a needed service in the downtown.

The third part of the survey asked shoppers to list problems they perceived in Merrimac Square. Vandalism, noise and loitering were the most frequently cited problems. Over 90 percent of the respondents felt these problems were a major concern. 
In contrast, few downtown users found parking to be a problem. Approximately 75 percent of those surveyed stated that they could always find a parking space. More concern was expressed over the location and accessibility of parking spaces than with the number of spaces available.

Few respondents found pedestrian safety to be a problem. This may be due to the fact that the Square is "automobilecriented". The availability of drive-up windows and convenience parking, etc., minimize the need for shoppers to cross the Square on foot. However, 58 percent of the respondents felt that the traffic intersection at the Square was dangerous and in need of improvement.

Most respondents felt public transportation was necessary. However, only 11 percent strongly supported this i-dea.

In terms of the public's perception of the Square's physical appearance, few respondents expressed concern over the aesthetics of the area. The majority (60 percent) disagreed that the buildings were in need of rehabilitation and 70 percent disagreed that signs and facades were cluttered and unappealing. In fact, most of those surveyed felt shopping in Merrimac Square was an enjoyable experience.

The open-ended questions merely reinforced some of the concerns raised earlier in the survey. Again, the teenager/ loitering problem was cited as the most serious problem. Those interviewed also provided some helpful suggestions as to possible solutions and/or actions the town could pursue ranging from the provision of handicapped access ramps to 
the development of a pedestrian auto-free mall. Many of these ideas will be considered in the development of specific strategies for dealing with Merrimac Square's problems.

\section{Loitering Problem}

Perhaps the only problem in Merrimac Square to be equally recognized by shoppers, merchants, the police and town officials is that involving teenage loitering. During the course of this study, an average of five to seven youths were observed during daytime hours and up to 15 youths between the ages of 16 and 24 years of age were observed during evening hours, congregating in front of the Richdale Store, the American Legion and the Merrimac Savings Bank.

A series of problems have been reported in connection with teenage loitering, including damage to private property, drinking, possession and sale of drugs, littering, graffiti, profanity, vandalism, noise, police assaults, breaking and entering, and intimidation of the public. In the month of June, 1981, a total of 175 calls were made to the Merrimac Police Department regarding nuisances in the Square. These amounted to 36 percent of the total calls made to the Department during this time period ${ }^{47}$.

Table 18 outlines the nature of these calls.

Table 18. POLICE CALLS INVOLVING MERRIMAC SQUARE - JUNE, 1981

$\begin{array}{lr}\text { Disturbances } & 40 \\ \text { Gatherings } & 42 \\ \text { Police Assault } & 4 \\ \text { Youths Drinking } & 44 \\ \text { Noise Complaints } & 45 \\ \text { Total Calls } & 175 \%\end{array}$

*Town of Merrimac Police Department Records, June, 1981. 
In the past year, five (5) breaking and enterings have occurred in Merrimac Square ${ }^{48}$.

Although there are many sociological explanations and a diversity of opinions regarding this problem, from the viewpoint of the Merrimac Police Department, it is partly due to a lack of police manpower and support from. the town. Budget cuts as a

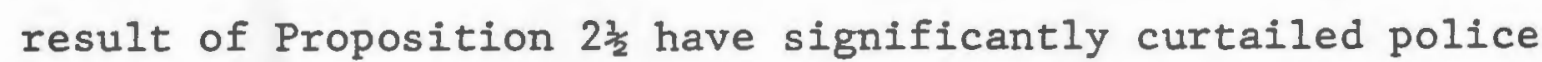
surveillance of the area and hampered their ability to control disturbances ${ }^{49}$. Although efforts have been made in the past to establish a youth center and youth activity programs, these projects have failed due to the town's refusal to provide necessary financial assistance. 
IV. GOALS AND RECOMMENDATIONS

\section{Introduction}

The preceding chapter identified a series of physical, economic and social concerns affecting Merrimac Square. The following briefly sumarizes the results of the needs assessment and problem identification portion of this study.

1. Merrimac Square is a center with a rich historic/ architectural heritage which should be preserved as a valuable asset. Measures should be taken to protect this resource from demolition, uncomplementary construction and inappropriate alterations.

2. Within the Square, there are a number of substandard structures which should be upgraded. Street/sidewalk improvements and landscaping are needed to enhance the aesthetics of the area.

3. An analysis of land use shows that vacant and developable land is available to accomodate future growth demands. However, land use controls are weak. They should be revised to promote commercial activity in the Square and to assure that new development is of high quality and compatible with the character of the area.

4. Traffic/circulation improvements should be made to facilitate a smooth flow of traffic and to improve the safety of both drivers and pedestrians. While the amount of parking is not an immediate problem, existing lots designated for public use should be upgraded and parking regulations should be better enforced.

5. Merrimac Square is experiencing considerable economic decline, evidenced by a high rate of business turnover, a relatively low level of investment in properties, existence of a significant amount of vacant and underutilized floor space, and the deterioration of commercial structures. Economic down trends are further supported by the results of the market analysis, which shows little market potential for office and retail space at present, and only slightly more promising forecast for the year 1995. This is largely related to Merrimac's slow but stable population growth trends, which are expected to continue over the coming fifteen-year period. 
6. Most interesting are the results of the shoppers survey. Generally, shoppers have a positive attitude towards the Square. They are content with the goods and services available, the overall aesthetics and physical conditions. In fact, they see few problems with the downtown. The most pressing concern expressed by the townspeople, merchants and local officials is the problem of loitering

All of the above concerns are interrelated and should be addressed as part of an overall strategy to revitalize the Town Center. This next chapter suggests a possible course of action for dealing with these issues and makes explicit the specific goals underlying these recommendations.

The overall goal underpinning this revitalization strategy is:

To create a central business district in Merrimac which is economically viable, healthy, safe, convenient; provides a pleasant and attractive environment for shopping, recreation, civic, cultural and service functions; and reinforces Merrimac's unique and rich historic heritage.

In making these recomendations the following should be noted. First, because of the intertwining nature of Merrimac Square's economic, physical and social problem, a comprehensive approach is essential. The recommendations presented, therefore, are also interrelated and should be considered as a package. Piecemeal implementation of these proposals will fail to bring about the desired results.

Secondly, it should be recognized that some of the proposed recommendations are in conflict with the general desires expressed by those surveyed. While the input of the shoppers was considered in developing proposals, the final recommendations are based upon a comprehensive assessment of the needs of the community as defined by data analysis, observation and the survey results. They were developed after a careful evaluation of their costs and benefits to the community at large and to the economic well-being of the Square. 


\section{Historic Preservation}

Goal: To protect Merrimac Square's valuable historic resources and to preserve the unique character of the Square.

\section{National Register Historic District}

Certify the significance of Merrimac Square by nominating the area to the National Register of Historic Places. The National Register of Historic Places is an official listing of the nation's architectural and cultural resources worthy of preservation. Listing in the National Register makes property owners eligible for historic preservation loans and grants, and offers protection against the adverse effects of federally financed and assisted projects. The Tax Reform Act of 1976 provides tax incentives to the owners of income producing properties, to encourage investment in rehabilitation and adaptive reuse.

2. Local Historic District

Designate Merrimac Square as a local historic district. Adopt a local historic district ordinance which requires the issuance of a "certificate of appropriateness" for new construction, exterior alterations, additions and demolitions. The purpose of such an ordinance would be to insure that structures of architectural/historical significance are protected from demolition and inappropriate alterations, and that new construction is compatible in design and scale with existing architecture. 
3. Visual Guidelines

Develop a Visual Guideline booklet to aid the Historic District Commission in evaluating exterior design treatments, when conducting reviews of building proposals. Such a booklet can also be used to assist property owners and merchants in selecting appropriate design solutions when undertaking construction and rehabilitation projects.

4. Other Projects

To further preservation effarts, the Historic District Comission should explore the feasibility of initiating a facade and scenic easement program. Seed money obtainable through housing rehabilitation grant programs could be used to provide financial incentives for exterior restoration work.

Physical

Goal: To reverse trends of physical decay and blight in Merrimac Square.

1. Replacement of Deteriorated Infrastructure Replace deteriorated streets, curbs and sidewalks where necessary.

2. Demolition

Demolish the dilapidated highway barn on Lancaster Court.

3. Rehabilitation

Encourage the rehabilitation of substandard structures by upgrading the investment climate in the Square. Designation of the area as a National Register Historic 
District would further this objective by making property owners eligible for investment tax incentives.

A second possibility is the establishment of a revolving loan to finance commercial rehabilitation projects. Map 13 identifies several structures which would be suitable for rehabilitation under such a program.

\section{Aesthetics}

Goal: To create a pleasant and attractive atmosphere for shopping, recreation, civic and service functions.

1. Street and Sidewalk Improvements

Improve the aesthetics of the square through the redesign and reconstruction of streets, sidewalks and parking areas. The widening of sidewalks, replacement and resetting of curbs, the installation of street triees (Lindens or Honey Locust), planters, brick paving and attractive street furniture (bikeracks, benches, trash containers) will give "new life" to the downtown. A unified urban design scheme should be developed and used throughout the area (see Map 12).

2. Coordinated Facades and Signs

Develop a coordinated program of facade, signage and awning improvements with the local merchants. Storefront rehabilitation incentives and grants should be used to stimulate local interest in this program.

3. Sign Ordinance

Update and revise the Sign Bylaw to better control the number, size, materials, design, and location of signs 


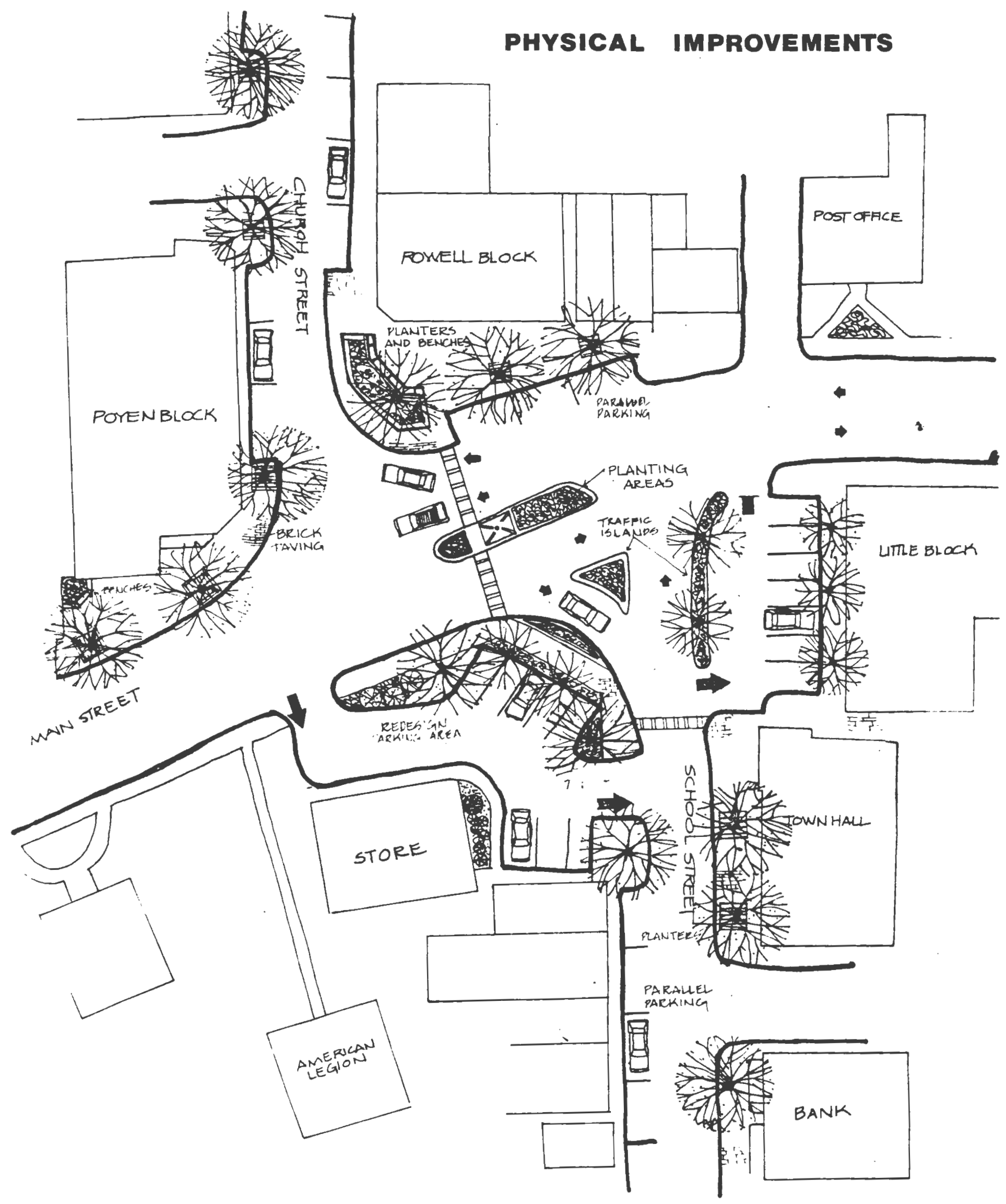

MAP 12 PHYSICAL IMPROVEMENTS 
on buildings. Develop design criteria for signs. Consider establishing a sign review committee or expanding the responsibilities of the Historic District Comission to include review of signs on a case by case basis. A public information brochure explaining the intent of sign controls and outlining design standards and review procedures may also be useful (see page 88).

4. Improved Access

Improve pedestrian access from the Municipal Parking Lot to the Square (the area between the Town Hall and Iittle and Larkin Block) with landscaping and brick and granite paving.

5. "New Image"

Provide a "new image" to the Square. Place well designed directional signs on Route 110 at the Town Line, colorful banners at the gateway to the Square and attractive markers throughout the Town Center, identifying parking areas, town facilities, the museum and other facilities. A comon theme, centering around Merrimac's historic heritage can be used for signs, banners and advertising material.

\section{Land Vise Controls}

Goal: To ensure that future development and expansion in the Square is compatible, orderly, well-designed, ecologically sound and beneficial to the social and economic well-being of the commity.

1. Town Center District

Restrict uses in the Square to high intensity uses. Implement the recommendation of the Master Plan by 


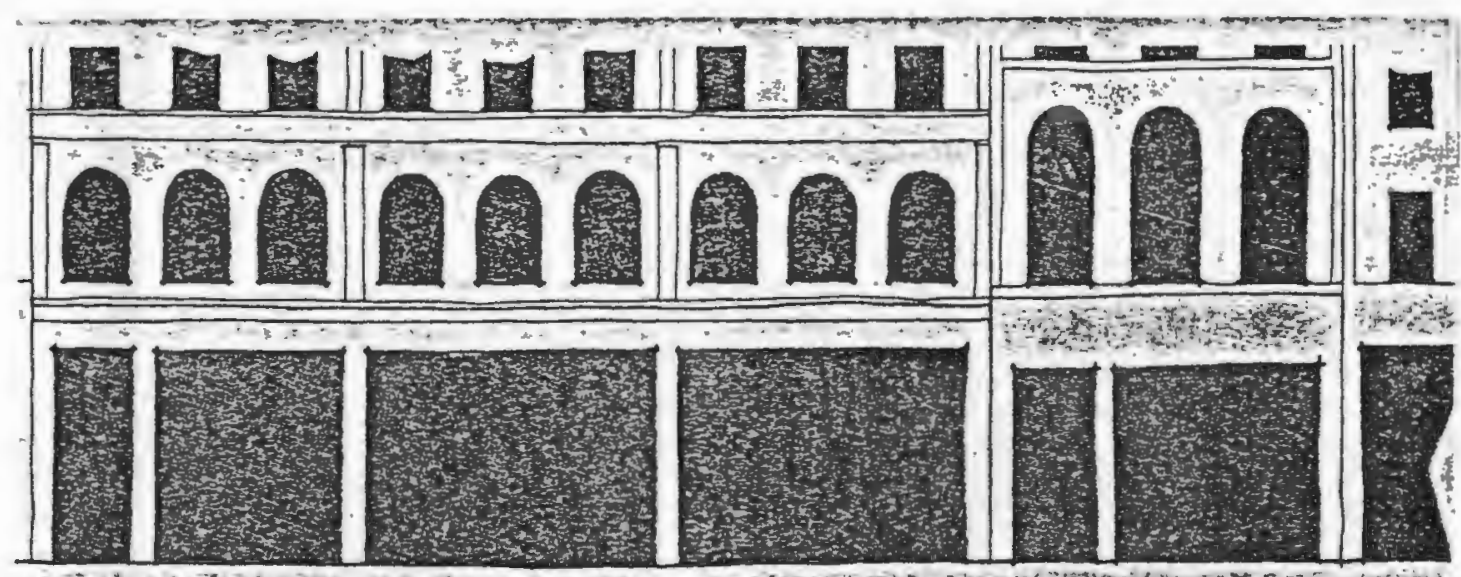

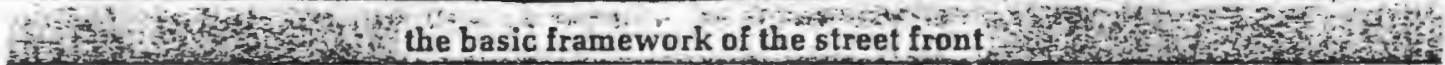

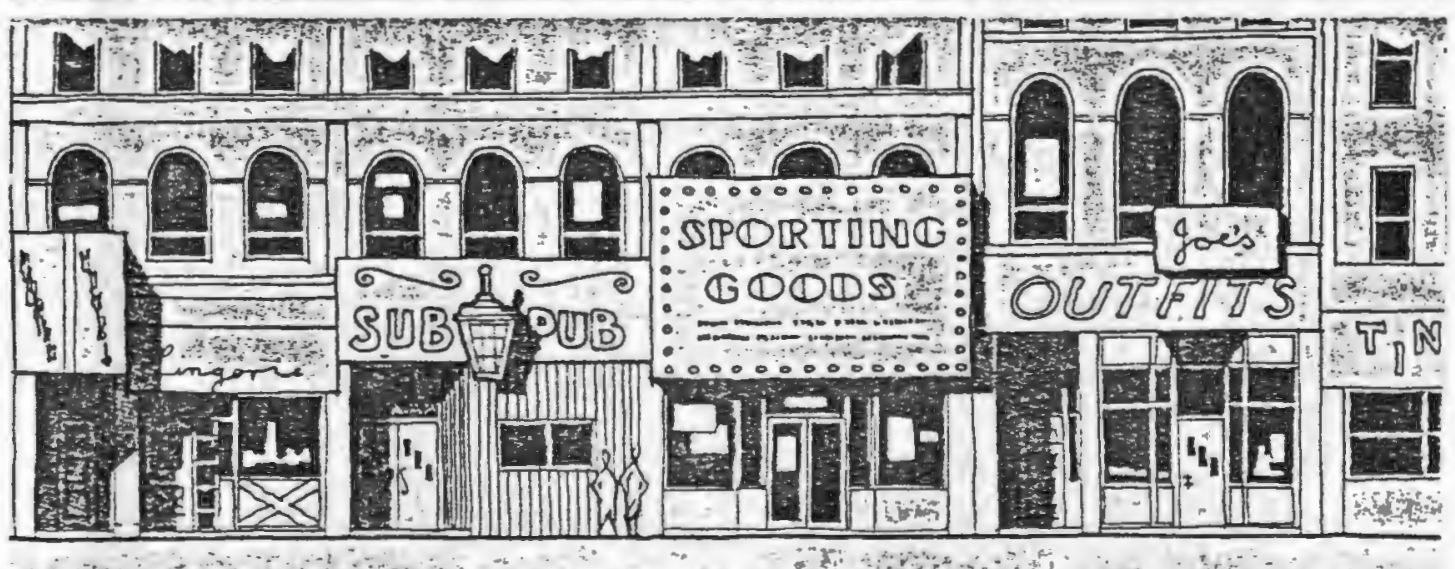

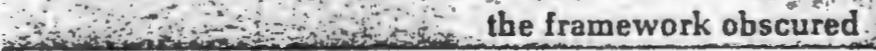

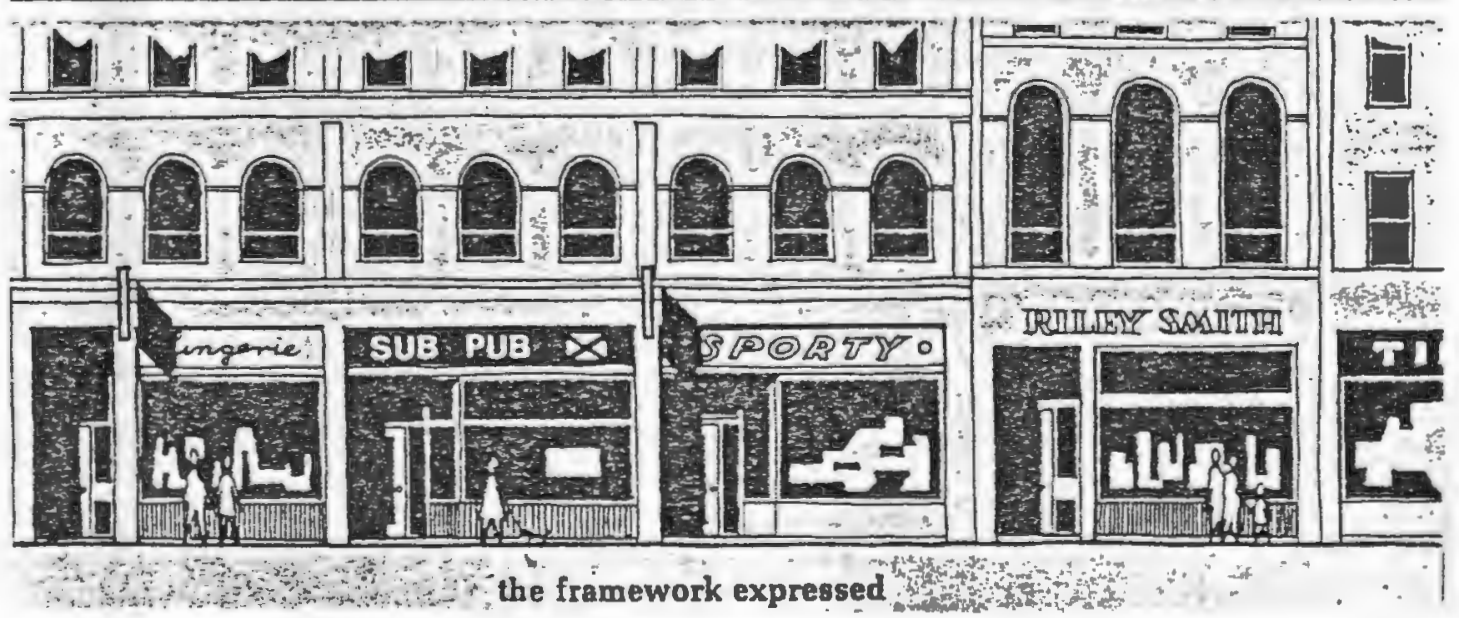

-The top drawing illustrates the basic framework of a building which must be respected if a sign is to be complementary and attractive.

-The middle drawing illustrates signs which are highly visible but obscure the framework and detract from the visual qiality of the structure.

-The bottom drawing illustrates signs which express the framework of the building and enhance the aesthetics of the building's facade.

Visual guidelines such as these can be incorporated into the Town's Sign Bylaw and Historic District Ordinance.

Source: Boston Redevelopment Authority, The Boston Sign Code, Boston, 1973. 
establishing a special Town Center District in which only retail uses, professional and business offices, hotels and guest houses, municipal and religious structures would be allowed by Special Permit after site plan review ${ }^{50}$. No highway-type commercial development should be allowed in this zone. Specific criteria for reviewing site plans should be established.

2. Conservation Buffer

A fifty-foot conservation buffer should be established on either side of Cobbler's Brook and Steven's Pond, to preserve the ecological integrity of these natural areas.

3. Height and Density Recuirements

Height and building coverage requirements should be considered for regulating development in the Town Center District. These regulations can be designed to be flexible in nature and used in conjunction with a density bonus program to attract quality commercial development to the downtown.

\section{Circulation}

Goal: To create a safe, efficient and convenient circulation pattern throughout the Square.

1. Traffic Improvements

Redesign and reconstruct the Merrimac Square intersection. Narrow the existing pavement and define turning and travelling lanes. Extend the existing traffic island and install a second island to direct traffic flow onto School street. A design solution for the intersection is proposed in Map 12. 
2. Install traffic signals at the Church Street and Main Street intersection to facilitate traffic flow and improve pedestrian safety.

3. Locate a synchronized flashing traffic signal at Broad Street and West Main Street, to function as an automatic stop light at the alarm signal and permit the safe exiting of emergency vehicles.

4. Minimize safety hazards to pedestrians by adequately striping crosswalks.

5. Provide curb cuts throughout the Square to permit handicapped access.

6. Consider the needs of bicyclists in all design and planning work.

\section{Parking}

Goal: To provide adequate, safe, and conveniently located parking to accomodate all business/retail uses and downtown functions.

1. Municipal Parking

a. Acquire approximately one-half acre of land behind the Town Hall building. Develop as a municipal parking lot with 24 parking stalls. The layout of the existing parking area should be redesigned with properly defined parking lanes and stalls, two points of access/egress, and facilities for off-street loading. Directional signs should be placed in the Square indicating the location of the "unicipal Lot. Municipal ownership and control of the lot will insure that parking needs are met well into the 1990's. 
b. Secure long term use of the Baptist Church lot to accomodate excess parking demands, employee/employer and commuter parking needs. In exchange for the use of this lot, the town should consider upgrading the parking area with suitable paving and landscaping.

2. On-Street Parking

a. Define, stripe and post all on-street parking zones.

b. Develop a parking enforcement system and enforce the one-hour time limit with agressive ticketing of violators.

c. Solicit voluntary compliance by local businesses in an effort to eliminate on-street parking by merchants and their employees.

d. Remove perpendicular parking in front of the Rowell Block and on School Street, in order to minimize traffic hazards, and accommodate new sidewalks, street trees and traffic improvements. Replace them with an eppropriate number of parallel parking stalls.

e. Better control parking in front of the Little and Larkin Block by installing a landscaped planting median to separate parking from through traffic on School and West Main Streets. (See Map 12.)

f. Prohibit parking near all intersections.

3. Off-Street Parking

a. Incorporate into the Zoning Bylaw, off-street parking regulations for all new commercial development. The number of spaces required should be based on established ratios of parking to square feet of building 
area. Special provisions for handicapped parking, off-street loading, design and layout of parking areas and landscaping should be stipulated as part of off-street parking requirements.

\section{Economic}

Goal: To stabilize economic conditions in Merrimac Square.

1. New Development

Attract new commercial development to the square and encourage the expansion of existing commercial structures using investment incentives available under the CARD (Commercial Area Revitalization District) Program. Apply for designation under that Massachusetts program. (See the Implementation section for discussion of the CARD Program.)

Map 13 identifies possible sites for new development and sites suitable for substantial rehabilitation which could utilize such incentives. New development in Merrimac Square will bring increased downtown employment as well as expand the town's commercial tax base.

(It should be noted that implementation of many of the physical improvement recommendations suggested above, will also serve to upgrade economic conditions by attracting new customers and investors to the area.)

\section{Social Concerns}

Goal: To mitigate the loitering problem in Merrimac square. 1. Increase police surveillance of the Square. 

2. Develop a youth center with activity programs. Possible locations for such a center include the American Legion Hall or Baptist Church meeting facilities.

\section{Housing}

Goal: To expand housing opportunities and meet the housing assistance needs of the community.

1. Housing Rehabilitation

Continue housing rehabilitation efforts in the Town Center Area.

2. Multi-Family Housing

Promote the development of quality multi-family housing in the Town Center Area by providing density bonuses and development incentives as recommended in the Merrimac Master $\mathrm{Plan}^{51}$. A possible location for multi-family housing is the land off Liberty Street. (See Map 13.)

3. Substantial Rehabilitation

Consider substantial rehabilitation of the Grange Hall and American Legion buildings as sites for subsidized elderly/family housing under the HUD Section 8 Program. 


\section{IMPLEMENTATION}

\section{Introduction}

The preceding chapter has outlined some possible solutions to Merrimac Square's problems and identified strategies for bringing about the revitalization of Merrimac Square. The translation of these ideas into completed projects is what implementation is all about. This last section will deal with how to initiate this process, by suggesting a possible organizational structure and exploring funding sources and financing mechanisms.

\section{Organizational Structure}

At present, no single group in Merrimac has assumed a leadership role in overseeing the development and revitalization of the Square. Several Town Boards, including the Selectmen, Planning Board and Board of Appeals, have jurisdiction in the development of policies governing the Square. Unfortunately, these groups often have conflicting ideas and concerns.

In the past, the business sector and others directly impacted by these policies, have not been actively involved in their development. Consequently, there has been little coordination and cooperation between the public and private sectors in addressing the problems of Merrimac Square.

To insure the participation of all affected groups, an organizational approach is recommended which actively involves the public, the business community and local officials. A comprehensive, coordinating type organization, made up of these varied interests is necessary to firm policy involving the square 
and act as a steering committee for implementation. A downtown revitalization committee, composed of representatives of the business community, landowners, bankers, citizens at large, local realtors, nembers of the Beautification Comittee, Historic District Commission, Planning Board and Selectmen should be established to serve this function.

The purpose of the Downtown Revitalization Committee would be to ascertain need, review final recommendations, develop alternatives, rank concerns, set goals, phase proposals and implement an overall plan for Merrimac square. This plan could be officially adopted by the Town Meeting and serve as an overall policy tool.

Involvement of the community at this stage is crucial because it serves to build support for future proposals. Provisions should be made to accommodate citizen participation, by holding several informatianal meetings and public workshops.

The Downtown Committee can also play a key role in the implementation process by rallying support for proposals, supervising the preparation of grant applications, and hiring consultants. It is essential that funding proposals include provisions for full-time development coordinator staff, to attend to the administration of grants, implementation details, and the exploration of additional funding sources.

Another organizational option which should be considered is tire establishment of a "Downtown Development Corporation." This organization could be similar in composition and function to that described above. However, it would also possess the additional advantage of being legally authorized to raise capital for projects 
through the sale of stock and levy of assessments. In Massachusetts, such agencies can acquire eminent domain powers and receive special tax abatements for redevelopment projects in blighted areas, under Mass Chapter $121 \mathrm{~A}^{52}$.

\section{Merchants' Group}

Regardless of the organizational structure of the revitalization implementing agency, it is essential that the merchants themselves become organized. The establishment of a Merrimac Square Merchants' Group is necessary. This organization would serve as a forum for voicing shared ideas and concerns about the Square, and give recognition to the merchants as a group. In some communities, merchant groups have become the prime mover behind revitalization efforts.

\section{Promotion}

The Merchants' Group could organize downtown promotional activities and special events such as concerts, fairs and sidewalk exhibitions, in an effort to attract new customers to the Square.

The Merchants' Group could also explore ways of improving Merrimac Square's image as a shopping district. A common theme, centering around Merrimac Square's importance as a horse carriage manufacturing center could be devised and used for advertising purposes. Signs and banners with this logo could be placed at the gateway of the town and in strategic locations in the Center to give a new identity to the Square. Such promotional efforts will not only bring new shoppers to the souare, but will attract potential investors and developers as well. 


\section{Private Entrepreneurs}

The role of the private entrepreneur is one which cannot be overemphasized as part of the revitalization strategy.

While the public sector can provide the necessary public improvements (street and sidewalks, parking and landscaping) and encourage private improvement through a variety of incentives (grants, CARD designation, tax breaks), the responsibility of investing in new development and the rehabilitation of existing structures lies with individual property owners, local lending institutions and businessmen. It is essential, therefore, that entrepreneurs are available and willing to invest in the downtown.

In order to achieve this, local merchants and businessmen may need to improve their entrepreneurship and management skills in order to make better investment decisions. A variety of programs are available to small businessmen, to assist them in broadening their knowledge of merchandizing, financial marketing and investment. Local merchants should be aware of these prograns and encouraged to participate in them.

It may also be necessary to actively seek investors from outside of Merrimac. A brochure, which projects Merrimac Square's "new" and progressive image as well as outlines its advantages for business location, should be developed and distributed to prospective developers, businesses and bankers in the area. Visits to stores, banks and offices to interest businesses in locating downtown should also be part of an overall marketing strategy.

Regardless of the approach, it is crucial that the political environment is supportive of investment. ventures undertaken by the 
private sector. Evidence of such support includes the implementation of public improvements, gaining CARD District designation and expediting local permit review processes.

\section{Financing and Funding Sources}

There are a variety of financing mechanisms and funding sources available to implement the recomendations presented in this report. A brief overview of these is provided below:

1. Municipal Financing Tools and Resources Improvements can be incorporated into the town's Capital Improvement Program and financed with General Town funds. Some of the larger projects may require longterm financing through the sale of municipal bonds. The town should explore the feasibility of Special Assessment Taxation for financing public improvements, such as streets, sidewalks and parking facilities, which benefit certain property owners more than the public at large. Each property owner, under this mechanism is assessed according to the benefit he receives by the improvement.

2. State and Federal Programs

To implement this revitalization plan, it is likely that the Town of Merrimac will need to seek financial assistance from the State and/or Federal governments. A list of possible funding sources is provided in Appendix $F$ of this report. As funding support for many State and Federal programs has been recently curtailed, the current and future status of these programs is uncertain and should be monitored closely. 
The programs discussed below are particularly appropriate to Merrimac Square's situation.

\section{A. State}

1. CARD (Commercial Area Revitalization District Program).

This program is specifically aimed at assisting older central business districts experiencing physical or economic decay. The CARD Program allows commercial businesses to utilize three development incentives, including:

1) 100 percent tax exempt revenue bond financing at lower than prime interest rates for new construction and adaptive reuse projects.

2) Mortgage insurance for rehabilitating commercial structures.

3) Urban Job Incentive Program, which allows tax reductions to commercial businesses who offer approved training programs.

A representative of the Executive Office of Communities and Development (EOCD), the State agency charged with the overall administration of the CARD Program, has already conducted a preliminary review of Merrimac Square. It was determined that the CARD Program is appropriate as a mechanism for solving the evident problems of commercial disinvestment. It was also determined that the Study Area Boundaries delineated in this report (Appendix G) are eligible for designation under the program52.

To qualify, Merrimac nust adopt a Commercial Area Revitalization District (CARD) plan which meets requirements established by EOCD. These regulations are included in Appendix $H$. The information contained in this report can be used as supporting material for the CARD plan.

\section{Massachusetts Government Land Bank Program}

This recently enacted State program is also aimed at assisting economically declining areas. The Land Bank, acting as a redevelopment agency, has the financial capability to acquire, clear and redevelop blighted land for resale on the private market. 
3. Massachusetts Community Development Finance Corporation (CDFC)

This program provides low-interest financing to businesses in economically depressed areas, through Community Development Corporations, for the purpose of expanding business opportunities and creating jobs.

4. Massachusetts Chapter 121 A

This program offers alternative forms of tax payments to redevelopment corporations, as incentives for encouraging residential, commercial, civic and recreation projects in blighted and substandard areas.

B. Federal

1. Community Development Block Grant (CDBG) Small Cities Program

This program, funded under the Housing and Community Development Act of 1974, is principally aimed at expanding economic opportunities and improving the living environment of low- and moderate-income families. A variety of activities are eligible for funding under this program, including public facility improvements, housing rehabilitation, historic preservation and economic development projects. Grants are awarded on a competitive basis, to comunities with populations under 50,000.

2. Urban Development Action Grant Program (UDAG)

This program also has an economic/community development focus and is designed to attract private investment in declining cities. The Town of Merrimac is eligible to participate in this program, as it meets the majority of "distress" criteria, established by HUD 54 . A variety of public improvement and revitalization projects are eligible for funding under this program.

3. Tax Reform Act of 1976

The Tax Reform Act of 1976 provides tax incentives to the owners of income-producing historic properties for rehabilitation and historic preservation projects. Under the 1976 Act, owners of properties within local certified historic district and/or historic districts or buildings on the National Register 
of Historic Places are eligible to recoup their investments through rapid amortization of rehabilitation expenses, or through accelerated depreciation of the structure.

3. Private Foundations

Foundations are private, non-profit organizations which are established for the purposes of assisting social, charitable and religious activities serving the public good. A number of foundations provide grants for civic improvement projects similar to those proposed by this report. The Foundation Grants Index and The Foundation Directory should be consulted to obtain an up to date listing of available grants.

4. Local Fundraising

Local fundraising efforts and private donations from residents, businesses and industries have made several of Merrimac's civic improvement projects possible in the past. This source of revenue should be considered again in implementing the Square's Revitalization Program. 


\section{CONCLUSION}

This study has identified the assets, problems and potential of Merrimac Square. A comprehensive revitalization strategy has been suggested to bring about the renewal of the area. It is up to the townspeople to put this plan into action. In doing so, it is important to keep in mind the following ten essential elements for a successful community revitalization program, as outlined by Robert $P$. Lynch, a specialist in the field 55

1. Vision

The community must have either a strong identity of its own or a vision of what it would like to become. The better this vision can be described in terms of realistic, concrete goals, the more likely the community is to be successful.

2. Dissatisfaction

Without strong sense of concern or dissatisfaction with problems of the commity, any effort to revitalize will be met by apathy, resistance, and complacency.

3. Cultural Activity

Cultural events such as ethnic festivals, and architectural sites play a significant role in building the image of the community and creating an exciting and inspiring environment that attracts customers, investors, and new residents.

4. Market Potential

Retail businesses along a commercial corridor are critical to sustain most urban communities. However, these businesses are doomed unless there is significant market potential in the area. Both a well executed market analysis and a properly aimed advertising campaign are the underpinnings of any economic revitalization effort.

\section{Entrepreneurs}

Risk-taking businessmen must be available and prepared to make investments in both retail stores as well as residential development. This may require a program to seek out or train new businessmen and provide business packaging assistance. 
6. Leadership

Local residents and businessmen must provide the direction, organization and commitment for any effort. When the leadership comes from the government, the project is likely to fail. And projects that overlook working with the surrounding residents are prone to conflict and stalemates.

7. Support

Broad-based political support is necessary in order to bring both funding resources and government agency staffing assistance to bear on thorny technical and bricksand-mortar problems. Full time professional support is likely to be necessary especially to assist and coordinate the large number of community volunteers who eventually become involved in these programs.

8. Money

Venture Capital and Public Money must be available for housing, small business developments, storefront improvements, roads, parks, and other physical improvements.

9. Time

Revitalization is not an overnight process. It involves changing people's attitudes and their decision-making patterns. It means constructing and rehabilitating buildings. It requires many meetings and social events. Generaliy $3-5$ years is a conservative estimate of the time necessary before enough momentum can be generated for the revitalization to be self-sustaining. Most people grossly underestimate the time necessary for this type of undertaking.

10. $\underline{\text { Plan }}$

Without a strategic and systematic plan, efforts are likely to be haphazard and superficial. An effective plan should not copy another community's plan but should be designed to meet your unique needs, probiems, and goals. The plan should have specific short-term goals as well as more general long term objectives. It should be time oriented with milestones, but these should be flexible in order to adapt to new needs and changing energies over the long haul. The plan must insure that visual improvements are occurring every 3-6 months to serve as observable reminders of progress. And the plan must deal very carefully and explicitly with human dynamics of the neighborhood, because revitalization brings change, and change brings conflict, which is probably the cost frequent cause of failure in the neighborhood econonic revitalization. 


\section{FOOTNOTES}

1. Town of Merrimac, Merrimac Planning Board, Master Plan, Merrimac, Massachusetts, prepared by Roy Mann Associates, Inc., February, 1977, p. 4.

2. U. S. Department of Comerce, Census Bureau, Social and Economic Characteristics of the Population, 1970 .

3. Town of Merrimac, Merrimac Planning Board, Master Plan, Merrimac, Massachusetts, prepared by Roy Mann Associates, Inc, 1977, P. 39.

4. Mary Marsh, Merrimac Senior Center, interview on July 24, 1981.

5. Merrimack Valley Planning Commission, Overall Economic Development Program, 1981, P. 59.

6. Town of Merrimac, Merrimac Planning Board, Master Plan, Merrimac, Massachusetts, prepared by Roy Mann Associates, Inc., 1977, P. 42 .

7. Merrimack Valley Planning Commission, op. cit., p. 62.

8. Town of Merrimac, Commity Development Block Grant (CDBG), Small Cities Program Grant Application, June 15, 1979.

9. Ibid.

10. Massachusetts Division of Employment Security, Massachusetts Cities and Towns, Labor Area Research Publication, Vol. 5, No. 5, May 1981 .

11. Ibid.

12. Town of Merrimac, Merrimac Planning Board, Master Plan, Merrimac, Massachusetts, prepared by Roy Mann Associates, Inc., P. 46 .

13. Arthur Evans, Chairman of Merrimac Planning Board, interview on July 12, 1981.

14. Town of Merrimac, Community Development Block Grant (CDBG), Small Cities Program Grant Application, June 15, 1979.

15. Ibid.

16. Arthur Evans, interview, July 12, 1981.

17. Arthur Evans, interview, July 12, 1981. 
18. Town of Merrimac, Community Development Block Grant (CDBG), Housing Assistance Plan, August 20, 1979.

19. Town of Merrimac, Community Development Block Grant (CDBG), Final Report, prepared by Kathryn Drown, Housing Rehabilitation Consultant, February 27, 1981.

20. U. S. Department of Commerce, Census Bureau, 1980 Census of the Population and Housing, Massachusetts, 1980.

21. Ibid.

22. Ibid.

23. Town of Merrimac, Merrimac Centennial Commission, Merrimac Historic Trail Guide, Spring, 1976, p. 5.

24. Ibid, p. 5 .

25. Ibid, p. 5 .

26. Ibid, pp. 17-30.

27. Ray Bastarashe, Town of Merrimac, Water Department, Interview on July $8,1981$.

28. Town of Needham, Needham Planning Board, Urban Design Study of Needham Center, prepared by MAPC, Metropolitan Area Planning Council, 1980, p. 16.

29. Town of Merrimac, Zoning Bylaw, 1978.

30. Nassachusetts Department of Public Works, Boston, Massachusetts, Traffic Counts for Route 110, Haverhill and Merrimac, 1981.

31. Massachusetts Department of Public Works, Proposed Areawide Topics Plan, Merrimac, Massachusetts, prepared by TippettsAbbett-McCarthy - Stratton, Engineers and Architects, November, 1972, p.8.

32. Town of Needham, Needham Planning Board, Needham Center: A Parking and Circulation Study, prepared by Sverarup and Parcel and Associates, Inc., 1979, p. 16.

33. Town of Merrimac, Merrimac Planning Board, Master Plan, Merrimac, Massachusetts, prepared by Roy Mann Associates, Inc., February 1977, p. 35.

34. Ibid, P. 34.

35. Massachusetts Department of Enployment Security, Employment Data, 1972-1979, provided by Allen MícDonald, Data Division, July 1981. 
36. Nancy Perkins, Merrimac Beautification Comittee, Interview on July 13, 1981.

37. Town of Merrimac, Building Permit Records 1976-1981.

38. Berk, Emanuel, Downtown Improvement Manual (Chicago, Illinois: American Society of Planning Officials, 1976), pp. 22-24.

39. Ibid, pp. 22-25.

40. Ibid, pp. 22-23.

41. Urban Land Institute, Shopping Center Development Handbook, Commity Builders Handbook Series, (Washington, D. C.: The Urban Land Institute, 1977), p. 4.

42. U. S. Department of Comerce, Census Bureau, 1977 Census of Retail Trade, 1977.

43. U. S. Department of Comerce, Census Bureau, Census of the Population, 1970.

44. Irban Land Institute, Dollars and Cents of Shopping Centers Handbook, (Washington, D. C.,: Urban Land Institute, 1975).

45. Berk, Emanuel, Downtown Improvement Manual (Chicago, Illinois: American Society of planning Officials, 1976), pp. 22-26.

46. Urban Land Institute, Shopping Center Development Handbook, Commity Builders Handbook Series, (Washington, D. C.: Urban Land Institute, 1977), p. 3.

47. Town of Merrimac, Police Records, June 1981.

48. Sergeant Alfred Nichols, Town of Merrimac Police Department, Interview, July 10, 1981.

49. Ibid.

50. Town of Merrimac, Merrimac Planning Board, Master Plan, Merrimac, Massachusetts, 1977, p. 70.

51. Ibid, p. 71.

52. Massachusetts Executive Office of Communities and Development, Massachusetts Chapter 121 A: A Handbook for Local Officials, November, 1979.

53. Mangini, Edmund, Commonwealth of Massachusetts, Executive Office of Communities and Development. Director of CARD (Commercial Area Revitalization District) Program. Interview and site visit, July 14, 1981.

54. Massachusetts Executive Office of Communities and Development, Memorandum from Joseph Flatley, Office of Policy Development, June 14, 1979. 
55. Lynch, Robert P., Community Organization Specialist, Warren, Rhode Island, 1977. 


\section{BIBLIOGRAPHY}

Bastarash, Ray. Town of Merrimac Water Department. Interview, July 8, 1981.

Berk, Emanuel. Downtown Improvement Manual. Chicago: American Society of Planning Officials, 1976.

Evans, Arthur. Merrimac Planning Board. Interview, July 14, 1981.

Frontiero, Wendy. Massachusetts Historical Commission, July 24, 1981 .

Gallant, Lee. Merrimac Square property owner. Interview, July 9, 1981 .

Greater Haverhill Chamber of Commerce. Business Directory for Greater Haverhill, May 1974 (update).

Hoffman, Gordon. Resident Engineer, Curran Engineers and Planners. Interview, July 9, 1981.

Hoyt, Jeffrey. Merrimac Town Improvement Society. Interview, July 24, 1981.

Mann, Roy. Roy Mann Associates, Inc. Interview, June 25, 1981.

Marsh, Mary. Merrimac Council for the Aging. Interview, July 24, 1981.

MacGregor, Nancy. Merrimac Board of Selectmen. Interview, June $23,1981$.

Merrill, Joseph. History of Amesbury and Merrimac, Massachusetts, Heritage Books, Inc., 1978.

Mangini, Edmund. Commonwealth of Massachusetts Executive Office of Communities and Development. Interview and site visit, July 14, 1981.

Massachusetts, Commonwealth of. Department of Commerce and Development. Merrimac City and Town Monograph. Revised November, 1973.

Massachusetts, Commonwealth of. Massachusetts Division of Employment Security. Massachusetts Cities and Towns, Labor Area Research Publication. April/May 1981.

Massachusetts, Commonwealth of. Massachusetts Division of Employment Security. Employment Data, 1972 to 1979. 
Massachusetts, Commonwealth of. Executive Office of Communities and Development, Massachusetts, Chapter 121 A: A Handbook for Local Officials, November 1979.

Massachusetts, Commonwealth of. Department of Public Works, Boston. Traffic Counts - Haverhill and Merrimac, 1981.

Massachusetts, Commonwealth of. Department of Public horks. TOPICS Plan, Merrimac, Massachusetts. Prepared by TippettsAbbett-McCarthy-Stratton. November, 1972.

Massachusetts Historical Commission. Inventory of Historic Assets, June 1975.

Merrimac, Town of. Merrimac Beautification Committee. A Plan for Merrimac Square. Prepared by Roy Mann Associates, Inc., 1973.

Merrimac, Town of. Merrimac Centennial Commission. Centennial Merrimac Historic Trail Guide. Spring 1976.

Merrimac, Town of. Small Cities Program Grant Application (Community Development Block Grant (CDBG)). June 15, 1979.

Merrimac, Town of. Housing Assistance Plan. Community Development Block Grant Program. August 20, 1979.

Merrimac, Town of. Final Report. Housing Rehabilitation Grants. Community Development Block Grant Program. February 27, 1981.

Merrimac, Town of. Merrimac Conservation Commission. Merrimac's Open Space and Recreation Lands, June 1977.

Merrimac, Town of. Merrimac Council on Aging. Merrimac's Buildings: Old and New. Audio Visual Presentation, written and narrated by Dorothy Robinson, 1976.

Merrimac, Town of. Merrimac Industrial Development Commission. Opportunities in Merrimac.

Merrimac, Town of. Merrimac Local Growth Policy Committee. Local Growth Policy Questionnaire, August, 1976.

Merrimac, Town of. Merrimac Planning Board. Master Plan Report. Prepared by Charles E. Downe, February, $1 \overline{964 .}$

Merrimac, Town of. Merrimac Planning Board. Zoning Map, January 1970 。

Merrimac, Town of. Merrimac Planning Board. Master Plan, Merrimac, Massachusetts. Prepared by Roy Mann Associates, Inc., February, 1977. 
Merrimac, Town of. Town Records: 1981 Property Valuations, 1975-1981. Building Permit Records and Land Sales

Transactions, Assessor's Work Cards, Town Reports 19701981, Assessor Maps.

Merrimac, Town of. Merrimac Police Department. Monthly Reports. May, June 1981.

Merrimac, Town of. Zoning Bylaw. Merrimac, Massachusetts, 1978.

Merrimac, Town of. Zoning Map, January 1, 1970, revised.

Merrimack Valley Planning Commission. Areawide Housing Opportunity Plan, May, 1980 .

Merrimack Valley Planning Commission. Overall Economic Development Plan, 1981 .

Merrimack Valley Planning Comission. Housing Profile. March 1977.

Needham, Town of. Needham Planning Board. Needham Center: Parking and Circulation Study. Prepared by Sverdrup and Parcel and Associates, Inc., 1979, p. 16.

Needham, Town of. Needham Planning Board. Urban Design Study. Prepared by MAPC, Metropolitan Area Planning Council, 1980.

Nichols, Sergeant Alfred. Merrimac Police Department. Interview, July 10, 1981.

Perkins, Nancy. Merrimac Beautification Committee. Interview, July 10, 1981 .

Ricker, George E. Reminiscences of West Amesbury and Merrimac on Wheels. Unpublished paper, October 1, 1931 .

U. S. Department of Commerce, Bureau of Census. Census of Population and Housing by Census Tracts, Lawrence-Haverhill SMSA, 1970.

U. S. Department of Commerce, Bureau of Census. Social and Economic Characteristics of the Population, Massachusetts, 1970.

U. S. Department of Commerce, Bureau of Census. Census of Retail Trade, 1977.

Urban Land Institute. Dollars and Cents of Shopping Centers, Washington, D. C.: Urban Land Institute, 1975.

Urban Land Institute. Shopping Center Development Handbook. Community Builders Hancbook Series. Washington, D.C.: Urban Land Institute, 1977.

Walton, Phyllis. Walton Real Estate Agency. Interview, July 15, 1981. 
APPENDICES 
I Appliance Store

1 Barber Shop

3 Banks

6 Business Offices

1 Drug Store

1 Flea Market

2 Grocery/Convenience Food Stores

3 Hairdressers

1 Hardware Store

2 Insurance Companies

1 Laundry/Dry Cleaners

1 Liquor Store

1 Oil Business

1 Printing Business

2 Restaurants

1 Toy Store 


\section{MVPC 2 merrimack valley planning commission \\ MERRIMAC SQUARE \\ SHOPPERS SURVEY}

The Merrimac Valley Planning Comission (MVPC) is sponsoring this survey to identify shopping habits and consumer attitudes towards Merrimac Square. It is part of a planning study being done on the Town Center.

Your responses will be helpful in determining the future of Merrimac Square and will be strictly confidential and anonymous.

Thank you for your assistance.

1. Sex Male

Female

2. Age (estimate)

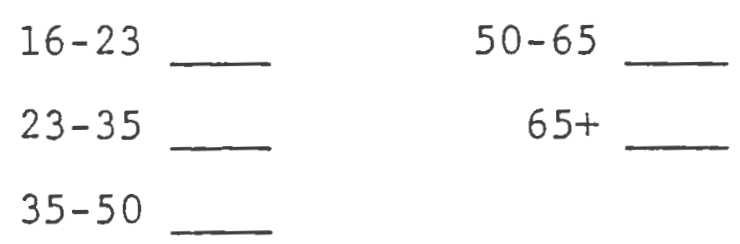

3. Resident of Merrimac? Yes __ No

If no, where?

4. How long have you lived in town? (Only if 非 applies)

\begin{tabular}{cc}
$0-3$ years & $10-20$ years \\
$4-10$ years & $20+$ years \\
\hline
\end{tabular}

5. What is the main reason for your coming to the downtown today?

To work

To shop (please specify)

For services (please specify)

For lunch (please specify)

For municipal business

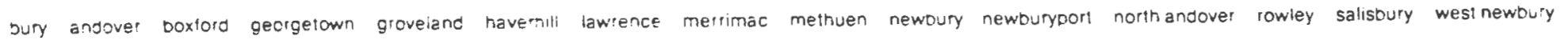


6. How often do you come to Merrimac Square?

More than once a week

Once a week

Once a month

Less than once a month

7. What types of stores or services would you like to see in the downtown that presently don't exist?

Discount store _ Delicatessen _ Fabrics Clothing

Shoes Doctor _ Gifts Theatre Dentist

Jewelry Grocery Store Lawyer Book Store

Specialty Restaurant Shoe Repair Florist

Gas Station Camera Other

8. If not at Merrimac Square, where do you do most of your routine shopping?

9. With regard to goods and services available in Merrimac Square, how would you rate the following:

Quality Excellent Good Fair Poor Selections Available Prices

10. I am going to read some statements regarding perceptions of Merrimac Square. Could you indicate whether you strongly agree, agree, disagree, or strongly disagree with these statements:

A. I can always find a place to park in Merrimac Square

B. Pedestrian Safety is a real problem in Merrimac Square

C. The buildings in Merrimac Scuare are badly deterioratéd and need rehabilitation

D. Shopping in Merrimac Square is an enjoyable experience

E. Downtown merchants and salespeople are helpful and courteous.

Strongly Agree
Strongly Agree Disagree Disagree Opinion 
PARRING SURVEY - MERRIMAC SQUARE - JULY 15, 1981

PARKING LOCATION

1. Merrimac Bay Bank

2. Town Hall

3. Cozy Cleaners

4. Baptist Church

5. Northeast Bank

6. Journeay

7. Richdale

8. Post office

9. Residence-Liquor Store 5

10. Elliot/Sargent

11. Burlington Medical

12. Engle Industries

13. East Main-South

14. East Main-North

15. School - West

16. School - East

17. Little Block

18. Joubert's

19. Church - East

20. Church - West

21 Grove street: TOTAL
NUMBER OF SPACES

247

22

8

60

20

11

9

6

5

$8 \cdot 2$

5

48

6

6

13

5

7

8

12

15

13

307

12

2

10

2

5

1

$$
3
$$

3

2

5

5

1

2

13

0

7

6

6

8

11

111
Number of Spaces Utilized $: 00$ A.M. 11:00 A.M. 1:00 P.M. 3:00 P.M. 5:00 P.1

9

96

16

13

3

7

4

2

2

3

3

6

2

5

5

5

8

0

5

2

8

4

102

0

11

0

5

0

2

2

2

3

2

2

5

3

07




\section{APPENDIX D}

BUILDING PERMIT ACTIVITY - MERRIMAC SQUARE STUDY AREA

$\underline{1976-1981}$

NO. OF PERMITS

ISSUED

DOLLAR VALUE

1976

1977

1978

1979

1980

1981

TOTAL
0

2

2

1

7

1

13

\begin{tabular}{c}
0 \\
$\$ 2,500$ \\
4,000 \\
300 \\
21,300 \\
2,000 \\
\hline$\$ 30,000$
\end{tabular}

Source: Town of Merrimac Assessor's Records 


\section{mope \\ merrimack valley planning commission
5 washingtion street, havernill, massachusetts 01830
$(617) 374-0519$}

MERRIMAC SQUARE

MERCHANTS SURVEY

\section{CONFIDENTIAL}

Name Address

Nature of Business Phone

1. How long have you been in business in this location?

2. How many people do you employ?

3. How many square feet do you occupy?

Total Sales Area

4. Do you rent or own?

What is rent?

Per (including utilities)

5. What major improvements (expansion, remodelling, etc.) have been made to property during the past five years or so?

Dollar value?

6. Average number of customers per day?

7. Where do your customers come from?

Merrimac Outlying Areas

Adjoining towns and region

8. Which describes your business plans over the next five years? No change in current space Major expansion Move from downtown to another location in town Move from Merrinac altogether 
9. What do you see as the major problems in locating here?

Inadequate parking

Inadequate space for expansion

inadequate loading areas

Inadequate zoning

The inability to attract customers

Lack of public investment/interest in Square

Vandalism and loitering

Other

10. What are the good features of Merrimac Square?

11. What are the negative features or problems not mentioned?

12. Has sales volume changed during the past five years?

$$
\text { Decreased Increased I_ Stayed about the same }
$$

13. What improvements would you like to see to Merrimac Square?

More customers

More parking

Street/sidewalk improvements

Coordinated signs

Better public transportation to Square

Traffic improvements

A storefront rehabilitation program

Other

\section{Comments}

14. Would you be interested in forming a Merrimac Square Merchants Group which could be aimed at dealing with the shared problems of Merrimac Square Business people and coordinating promotional efforts? 
Massachusetts Technolog Develop=er:t Corporation

Independent public corporatios providing direct flnancing and management assistance to start-up and young technology-based companies. Loans are matched with investments from cutside scurces. As this organization is funded by EDA, it may be of limited assistance in the future.

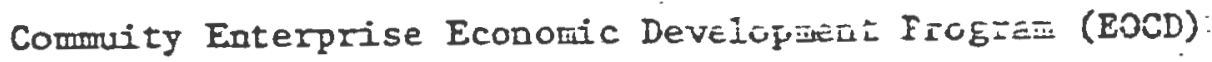

Provides funding for comurifiy devejupuint corporations and other :-

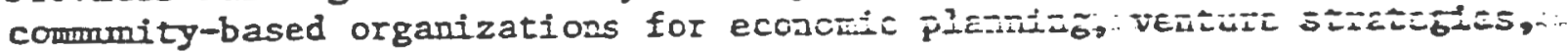
and leveraging.

Small Business Administration

Section 503: Loan guarantees to gualified local development companies assisting small businesses. May be used to finance land and plant acquisition, construction, conversion or expansion; includes acquisition of machinery and equipment. Company invests $10 \%$ of total costs.

"Leeway" Lar

This state Iar allows savings banks and cooperative banks to provide initial development equity and/or financing. Also, through a solely owned subsldiary, a bank can purchase, develop, and manage property.

Commercial Area Revitalization District (CARD)

State program under which local board or agency submits plan for revitalization of oldeI; declining comerclal district. Plan will include public action and use of developwent incentives. When plan is approved the following development incentives become available to developers:

- Tas exempt revenue bond financing at several points below prevailing conventional interest rates.

- Mortgage insurance for rehabilitation of comercial buildings.

- Urban Job Incentive Program: Excise tax credit and 257 payroll deduction.

Commity Development Block Grant - Stall Cities (CDBG) (HUD)

Grants for various activities such as acquisition, rehabilitation, or coastruction of public works facilities and improvements; clearance; housing rehab; econoric development. May be one year (single purpose) or tiree years (comprehensive). 
Massachusetts Industrial Finance Agency (MIFA)

State agency offers low-interest loans (industrial revenue bonds) for manufacturing, research and development, or warehouse and distribution firms; financing must be for newly constructed, newly acquired, or improved plant and equipment. Also provides mortgage loan insurance which allows company to borrow more of projects' cost at low-interest rates and thus conserve cash for working capital. Also pollution control financing and assistance in Commercial Area Revitalization Districts (CARD).

Farmers Home Administration Business and Industrial Loans

Guaranteed loans (up to $90 \%$ of principal and interest) for public, private or cooperative organizations or rural individuals. Loans issued for business and industrial acquisitions; construction, repair, modernization, purchase of land, machinery, equipment; start-up and working capital. Minimum loan is generally $\$ 500,000$. Proposed to be phased out in FY82.

Farmers Home Administration Industrial Development Grants

Direct grants to rural towns to develop business and industrial sites (e.g., provide utilities). Average grant $\$ 35,000$. Proposed to be phased out in FY82.

Industrial Revenue Bonds (IRB's)

Issued by municipality to finance construction, improvement, purchase or expansion of manufacturing facilities or construction of solid waste disposal facilities, or purchase air or water pollution controls. The bonds secured by credit of industrial tenant, not municipality, although they may be processed and issued by the mmicipal Industrial Development Financing Authority.

\section{Small Business Administration (SBA)}

Section 502: Loans to corporations formed by at least 25 citizens interested in planned economic growth of community with at least $75 \%$ ownership/control held by those living or doing business in the community. Used to buy land, machinery, equipment; acquire, expand, convert existing plant. $\$ 500,000$ maximum loan; company must provide $10 \%$ of project cost. The user of the facility (as opposed to the development company) must be a small business: independently owned and operated, under 250 employees, assets under $\$ 9$ million; average net income (after federal income taxes) under $\$ 400,000$ for preceding two years. 
Massachusetts Capital Resource Company

Privately-owned fund of Massachusetts life insurance companies. Acts as a source of capital for Massachusetts businesses which are unable to obtain conventional financing. Does not cover real estate developers, retailers, construction contractors. Loans range from $\$ 125,000$ to $\$ 5$ million dollars and average $\$ 1$ million dollars (1979).

Massachusetts Business Development Corporation

Privately-owned pool from financial institutions interested in investments that will sustain and produce jobs in Massachusetts. Loans may be for working capital, second mortgages, SBA loans (503), government guaranteed loans, new equipment or energy conversion. Borrower must be unable to obtain conventional financing. Terms and interest rates vary. Loans range from $\$ 75,000$ to $\$ 500,000$. Loans made to manufacturers, distributors, service industries, and for industrial and commercial real estate.

Massachusetts Community Development Finance Corporation

Invests capital in business ventures undertaken in conjunction with community development corporations (CDC) in economically depressed areas. Eligible businesses may be privately or CDC owned. Leverage of other private and/or public funds is also sought. Businesses should create jobs suitable for the local work force and/or provide a means for increasing the community's self-sufficiency.

Massachusetis Government Land Bank

Independent state agency works with municipalities, developers, and private and public development entities. Acquires, improves and disposes of property. Can perform rehabilitation, site preparation, infrastructure, demolition. Cost of site improvements added to mortgage prior to resale. Emphasize mixed use (e.g., commercial/residential) projects. Mortgage rates reflect bond prices. Most projects range between $\$ 100,000$ to $\$ 700,000$.

Community Economic Development Assistance Corporation

This quasi-independent state group provides technical assistance to community development corporations and other non-profit comnuity-based organizations in areas where the average income is under $\$ 9,300$, and may help informally in other areas. Can work with new businesses on efficient management, finencial packaging, marketing strategy, and feasibility studies. 
LEGAL DESCRIPTION OF BOUNDARIES FOR PROPOSED

COMMERCIAL AREA REVITALIZATION DISTRICT (CARD)

The following is a legal description of the revitalization district in fulfillment of Commercial Area Revitalization District (CARD) Program requirements. Parcel numbers refer to the Town of Merrimac's Assessor's Map numbering system.

- Begin at the intersection of West Main Street and Little Court at the southwest corner of Parcel 3-1-4.

- Then, proceed in a northerly direction along Parcel 3-1-4 to a point at the intersection of Parcel 3-1-23.

- Then, follow east along the rear lot lines of Parcel 3-1-4 and Parcel 3-1-3 to the intersection with Parcel 3-1-2.

- Then, proceed in a northerly direction along the westerly boundary of Parcel 3-1-2 to Grove Street.

- Then, proceed in a northwesterly direction across Grove Street to the southwest corner of Parcel 4-1-28.

- Then, follow in a northerly direction along the boundaries of Parcel 4-1-29 to the nerthern border of Parcel 4-1-4.

- Then, proceed east along the northern border of Parcel 4-1-4 to Church Street and continue in the same direction along the rear property lines of Parcels 1-4-1, 1-4-2, and 1-4-3 on Mechanic Street to Liberty Street.

- Then, follow the rear property line of Parcel 1-3-2, across Steven's Pond and along the rear boundary of the Municipal Building Land to eastern boundary of the Town Improvement Society Land.

- Then, follow the eastern border of said to the intersection of Broad Street, East Main Street and Parcel 13-2-1A.

- Then, follow south along the rear property boundary of Parcel 13-2-1A and Town owned Parcel 13-14.

- Then, proceed west along Parcel 13-14 to Broad Street and Lancaster Court.

- Then, proceed west along the north side of Lancaster Street across School Street and continue along the southerly boundary of Parcel 7-1-23 to the intersection with the southwest corner of Parcel 7-1-7. 
- Then, follow the westerly border of Parcel 7-1-7 to its intersection with Parcel 7-1-8A.

- Then, proceed along the southern and western border of Parcel 7-1-8 to the starting point at the intersection of Little Court and West Main Street. 


\title{
CARD PLANS \\ Rules and Regulations
}

\section{Commercial Area Revitalization District Plans}

Commonwealth of Massachusetts

Edward J. King, Governor

\author{
Effective April 28, 1981
}

Executive Office of

Communities and Development

Byron J. Matthews, Secretary 
751 CMR is amended by deleting 751 CMR 8.00 and replacing it with the following new 751 CMR 8.00:

751 CMR 8:00: COMMERCIAI AREA REVITALIZATION DISTRICT (CARD) PLANS

Section

8.01 Introduction

8.02 Criteria for Plan Approval

8.03 Procedures for Gaining CARD Plan Approval

8.04 CARD Plan Documentation

8.05 Severability

8.06 Appendix: Exhibits I, II and III

8.01: Introduction

(1) What is the CARD Program? The CARD Program was established by the Massachusetts Legislature to assist communities with older downtowns experiericing commercial decay. The CARD Program works to reverse this trend by stimulating public and private investment. The public provides needed capital improvements and the private sector uses the CARD Program's financial incentives to reverse the cycle of commercial disinvestment.

(2) Which Communities are Eligible for the CARD Program? Every Massachusetis municipality which has a commercial center that meets the following criteria:

- It must be an older established commercial center.

- It must be experiencing commercial disinvestment which may be described in terms of: commercial buildings with a large vacancy rate; loss of significant retail businesses; loss of commercial sales; or physically deteriorating commercial buildings.

(3) How can the CARD Program be used in a City or Town? (a) Communities committed to revitalizing their downtown can, with an approved CARD Plan, offer financial incentives to developers willing to invest in the CARD area.

(b) The incentives available for developers of commercial projects are: tax-exempt revenue bond financing at interest rates usually several points below conventional rates; mortgage insurance for rehabilitation projects; and the Urban Job Incentive Program. Urban Job incentive Program (UJIP) provides two forms of tax reduction:

1. A credit against a corporation's state excise tax liability.

2. A 25 percent payroll deduction.

(c) For more information on the Urban Job Incentive Program, contact the Department of Manpower Development at 727-6446.

Commercial projects may include the construction of a new building or the rehabilitation of $a \Gamma_{1}$ existing building for commercial purposes (i.e. hotels, office space, restaurants). Mixed use projects include the rehabilitation of any single building for mixed commercial and 


\subsection{1: continued}

residential use. Legislation requires that MIFA and the local governing body in which the project is located make certain "blight findings" for each mixed use project. For more information on these development incentives and the blight findings required for mixed use projects contact The Massachusetts Industrial Finance Agency (MIFA) at $723-4242$.

(4) What is the Procedure for Gaining CARD Plan Aporoval? first step for a community wanting to know more about the CARD Program is to contact the Executive Office of Communities and Development (EOCD) at 727-7001.

A pre-application meeting will be arranged with agency staff to discuss the economic problems the community is experiencing and the various alternative ways for addressing those problems.

If at the pre-application meeting it appears that the CARD Program will work for the community, Section 8.04 of these guidelines outlines the format for writing a CARD Plan.

The draft CARD Plan must have EOCD approval of the proposed boundaries and the draft plan prior to the public hearing.

The draft CARD Plan, having received the local governing body's approval, should be submitted to EOCD for review.

(5) How Long is the CARD Plan aporoved for and is it Renewable? CARD Plan approval shall remain in effect for two years. Renewal of a CARD Plan, to a large extent, will be dependent on the implementation of the development incentives and also the extent the community has followed through on its public improvement commitments. Communities seeking to renew their CARD Plan should contact EOCD to obtain a CARD Plan Renewal Form. Resubmission of a CARD Plan does not require local governing body approval.

\subsection{2: Criteria for Plan Approval}

In order for the Secretary to approve the CARD Plan, the following findings must be made:

(1) That the plan boundaries describe a predominatly commercial geographic area.

(2) That the proposed CARD area is suffering from commercial decay which may be described in terms of: the trend in market conditions over a period of years; the movement of commercial enterprises out of the proposed CARD area; loss of commercial sales; commercial buildings with a large vacancy rate; or physically deteriorating buildings.

(3) That the Plan describes specific strategies designed to reverse the commercial decay. The strategies should include:

(a) Public actions required to reverse the commercial disinvestment;

(b) The use of development incentives in the development and redevelopment of the CARD area. 


\subsection{2: continued}

(4) That the local governing body (defined as "in a city having a Plan D or Plan E charter, the city manager and the city council and in any other city the mayor and city council, and in towns the board of selectmen") of the municipality has approved the plan.

(5) That the business community was involved in the planning of the CARD.

(6) That a strategy has been designed to publicize and educate the business community concerning the development incentives available under the CARD Plan.

(7) That the CARD Plan takes into account any operative municipal master plan, urban renewal plan, economic development plan, or other officially adopted local plan covering all or part of the CARD area.

(8) That a local agency has been identified with the capability to oversee implementation of the CARD Plan, in addition to being responsible and accountable for the marketing of the CARD Plan.

(9) That the local governing body has held a public hearing on the CARD Plan prior to approving the Plan and forwarding to EOCD for final review.

\subsection{3: Procedures for Gaining CARD Plan Approval}

(1) The Pre-application Meeting. As discussed in the Introduction, the first step when planning a CARD Plan is to contact EOCD to arrange a pre-application meeting. The purpose of the pre-application meeting is to discuss the problems of commercial disinvestment that are ocurring in the particular community and then to determine if the CARD program is an appropriate mechanism to assist in solving those problems. Thus, the pre-application meeting plays a key role in determining the eligibility of an area for CARD designation.

If at the pre-application meeting it has been determined that the CARD program is appropriate, the municipality will be asked to submit a draft plan to EOCD. The plan must follow the format outlined in 751 CMR 8.03. Pre-existing plans (such as an Urban Renewal Plan or a Downtown Revitalization Plan) may be used as supporting material for a CARD Plan; however, they may not be used in lieu of a CARD Plan as outlined in 751 CMR 8.03 .

EOCD will comment on the completeness of the draft CARD Plan within ten working days of receiving the Plan. The Secretary or his representative may ask for additional information if it is determined that the CARD Plan is incomplete.

A CARD Plan must have EOCD approval of the draft plan and proposed boundaries prior to the public hearing.

(2) CARD Plan Submission. Four copies of a complete CARD Plan shoulc be submitied to tie Secretary of Communities and Development. 


\subsection{3: continued}

(3) Approval Letter. Upon determination by the Secretary that the proposed CARD Plan satisfies all of the criteria outlined in Section 8.02, he shall issue a letter of approval. The Secretary's approval of the CARD Plan may involve conditions. The intent of such conditions would be to help insure that the development incentives will be applied only for uses consistent with the purpose of these regulations and their underlying statutes.

(4) CARD Plan Changes and Amendments. The municipality shall submit all major changes to approved CARD Plans to the Secretary of Communities and Development for approval. A major plan change is defined as a change in either the CARD's boundaries, the designated local implementing agency or in the case of CARD Plans approved prior to October 15, 1980, the inciusion of a housing, or mixed use component. Communities seeking to change their CARD Plan should refer to Exhibit I, "How to Amend an Approved CARD Plan".

(5) Plan Aporoval and Renewal. Approval of CARD Plans under these Rules and Regulations will remain valid for two years from the date of their approval by the Secretary of Communities and Development.

At the end of the two years, EOCD will review each CARD Plan to determine if the Plan should be renewed for an additional two years. Renewal of the Plan wil be dependent on:

(a) The use of the development incentives to date:

(b) The extent to which the municipality has followed through on its commitments to the CARD. These commitments include both the public improvements and the strategy for involving the business community in the CARD Plan.

If the above criteria has been met, a letter of extension will be issued. If it is determined that either of the above goals has not been achieved, the municipality will be granted a one-year extension of CARD designation to follow through on its commitments. If at the end of that period significant progress has not been made toward achieving the objectives outlined in the plan, the Secretary will not renew the CARD Plan approval. If a CARD Plan is not renewed, commercial projects that received "official action" while the initial CARD approvai was in effect from either MIFA or the municipality or have been financed through Industrial Revenue Bonds will not be affected.

CARD Plans which have received EOCD approval prior to April 16, 1980 will be valid for three years from the date of their approval by the Secretary of Communities and Development, subsequent approvals will be for 2 years.

\subsection{4: CARD Plan Documentation}

Each of the following sections must be addressed in the CARD Plan. The Plan should follow the numbering as it appears below: 
8.04: continued

(1) Rationale for Designating the CARD. The Plan shall include a statement describing the economic development problems the proposed CARD area is experiencing. This discussion should document specific information on commercial disinvestment and decay. This discussion should include a description of market conditions over the past several years, i.e., the character and stability of commercial mix, a description of occupancies and vacancies in commercial space; loss of sales; condition of residential property (if any), including building code violations.

(2) Plan Objectives. Having outlined the economic problems occurring in the proposed CARD area, the. Plan should include a discussion of how these problems will be addressed. The objectives of the Plan should directly relate to the problems outlined in Section (1) above and should include a statement on how existing commercial enterprises will be encouraged to remain in the CARD area.

(3) CARD Boundaries.

(a) The Plán shall include a brief statement on the reasons for delineating the bouridaries of the CARD Plan. When the CARD being proposed is for an existing commercial area other than the given locality's Central Business District (CBD), the Plan shall include the rationale for designating the area.

(b) The Plan shall contain:

1. an accurate description of the CARD boundaries.

2. a map (s) (attached to the plan) which clearly delineates the CARD boundaries identifies all major streets within the CARD, and locates the CLRD within the city or town.

(4) Land Use and Zoning. The Plan shall contain the following: (a) A map of existing land uses.

(b) Documentation indicating that the predominant land use within the CARD is commercial. (The statement should be made in terms of acreage.)

(c) Maps and text as appropriate to document existing zoning status of the CARD.

(d) If the CARD boundaries contain areas that are not now used for commercial purposes, but which are intended to be converted or used for commercial purposes in the future, the plan should include a statement outlining the zoning or land use changes that will be occurring. Final approval will not be granted by the Secretary of EOCD until these changes are made.

(e) If the CARD boundaries contain areas that are not now used for mixed use purposes, (combined housing and commercial development) but which are intended to be converted or used for mixed use purposes in the future, the plan should include a statement outlining the zoning or land use changes that will be required and a strategy to achieve such changes. 


\section{CMR: EXECUTIVE OFFICE OF COMMUNITIES}

AND DEVELOPMENT

\subsection{4: continued}

(5) Plan Strategy. The Plan shall describe specific strategies designed to reverse the commercial decay described in Section (I) above including:

(a) Public Improvements and Facilities. Describe in general terms any major public improvements envisaged, including major changes in traffic circulation and provision of off-street parking, utilities, streetscaping, pedestrian malls, parks, and plazas. Describe any major public facilities to be provided.

(b) Lise of Development Incentives Available Within Approved CARD Areas. If this plan were to receive approval, briefly describe each project of which you are aware that could utilize the development incentives (revenue bonds, mortgage insurance, UIIP). (c) General Character of Development/Redevelopment. Outline of general character of development or redevelopment envisioned including:

1. the extent to which the development/redevelopment will emphasize the upgrading of existing businesses, the expansion of existing businesses, and the attraction of new types of commercial enterprises.

2. the extent to which, if any, the development/redevelopment will include the reuse of existing buildings for mixed use (housing and commercial) development. The plan should include a description of the community's housing needs, especially in the $C A R D$ area, the nature and type of housing planned to meet those needs and the various groups the housing is expected to serve.

3. the nature and character of new marketing techniques that will be undertaken by local merchants.

(d) Local Financial Commitment. Indicate present and projected local budgetery commiment to the CARD, including issuance of general obligation bonds and allocations of entitlement or small cities CDBG funds. Specific dollar amounts should be stated where possible.

(e) Compatibility With Downtown Development. If the CARD Plan being proposed consists, in whole or part, of areas outside the locality's CBD, summarize those features of the Plan Strategy that will ensure that revitalization of the proposed CARD will complement rather than compete with the preservation and/or revitalization of the downtown proper.

(i) Iand Use and Design Controls. Indicate whether land use and design controls will be required to carry out the. Plan, and, if so, what type of controls including signage and historic district or historic register designation. Also describe procedures for design review currently in effect or which may be established.

(g) Finding of Corformance with Other Local Plans. The submission shall identify any pre-existing plans, including local master plans and urban renewal plans, that apply to all or part of the CARD and that have been approved by the local governing body or a specific muricipal agency. In each case, as appropriate, either: 
8.04: continued

1. affirm the consistency of the pre-existing plan with the CARD Plan, or

2. describe the nature and extent of any inconsistency and how it will be resolved.

(h) Business Community Participation Provision. The Plan shall contain the following:

1. How have the merchants and other businessmen in the proposed area been involved in formulating the proposed CARD Plan?

2. How will merchants and financial institutions be involved in marketing the plan?

3. What is the strategy of the implementing agency for informing the "business and banking" community of development incentives available in approved CARD areas?

4. The implementing agency may want to consider whether or not citizens within the given area should be involved in the implementation of the CARD Plan.

(i) Local Implementing Agency. The submission shall identify which local agency has been designated to oversee implementation of the CARD Plan and describe the powers and experience of the agency which qualify it to perform this function. The designated agency should have the overall responsibility for community development (i.e., Community Development Departments or Planning Departments or Redevelopment Authorities).

(j) Evidence of Public Hearing. The submission shall include evidence that a public hearing was held by the local governing bocy on the CARD Plan and that the hearing was preceded by ten days' notice. The boundaries of the Plan presented at the public hearing should be the official CARD boundaries (i.e., already approved by EOCD). If these boundaries are changed in any way after the public hearing and before being approved by EOCD. another public hearing must be held to inform the community of the boundary changes. The public hearing should be held within the area being proposed as the CARD. If this is not possible, the hearing should be held within a reasonable distance to the CARD. (k) Additional Documentation Required.

1. Resolution of Local Governing Body. Exhibit A provides model language for a resolution by the local governing body epproving the CARD Plan.

2. Certificate of Recording Officer. Exhibit B provides model language for a certificate by a recording officer attesting that the resolution of the governing body as submitted to EOCD is a valid one.

3. Opinion of Iegal Counsel. The submission shall include an cpinion by the municipality's legal counsel that the CARD Plan was prepared and approved in accordance with applicable state and local statutes and regulations. 


\subsection{5: Severability}

If any provisions of these regulations or the application thereof is held to be invalid, such validity shall not affect other provisions of the application of any other part of these regulations not specifically held invalid, and to this end the provisions of these regulations and various applications thereof and declared to be severable.

\subsection{6: Appendix}

\section{EXHIBIT I}

\section{GUIDELINES FOR AMENDING APPROVED CARD PLANS}

The municipality shall submit all major plan amendments to the Secretary of Communities and Development for approval. A major plan is defined as a change in the CARD boundaries, the designated local implementing agency or in the case of CARD Plans approved prior to October 15, 1980 the inclusion of a housing or mixed use component.

Procedures for gaining approval of a proposed amendment to a CARD plan. A letter of intent to amend an approved CARD plan should be mailed to the CARD Coordinator, EOCD, Room 904, 100 Cambridge St., Boston, MA 02202. The letter of intent will be reviewed by the Coordinator for completeness, consistency with the CARD legislation, and a determination if a public hearing will be required. Depending on the nature of the proposed amendment, a visit to the area may or may not be necessary. The CARD Coordinator and the Division Administrator will forward their recommendation to the Secretary.

NOTE: Communities desiring to change the implementing agency need only submit a letter of intent. A public hearing is not required.

An amendment to the CARD Plan to include a change in the CARD boundaries for communities seeking to amend their CARD boundaries the amendment should contain the following documentation:

1. A map (with streets legibly identified) of the existing CARD boundaries and the proposed changes to those boundaries, if any, the land use of the approved CARD area and the area proposed for inclusion in the CARD (the entire CARD area must be predominately commercial).

2. A description of all development/redevelopment anticipated in the proposed CARD area.

3. A description in general terms of all major public improvements envisioned in the area.

4. The local financial commitment to the CARD, including issuance of general obligation bonds and allocations of entitlement or small cities CDBG funds

5. EOCD will determine if a public hearing on the proposed boundary changes are necessary. If it is determined that a public hearing is required, the following documentation must be submitted: 
751 CMR: EXECUTIVE OFFICE OF COMMUNITIES

AND DEVELOPMENT

8.06: continued

- Resolution of local governing body approving the Plan amendment (Refer to Exhibit-for Sample Resolution)

- Certificate of Recording officer attesting that the resolution of the governing body as submitted to EOCD is a valid one.

An amendment to the CARD Plan to include a mixed use component. Prior to the Massachusetis Industrial Finance Association taking official action on the proposed project, MIFA will be responsible for determining if communities intending to use an Industrial Revenue Bond for a mixed use (housing and commercial development) project in an approved CARD area will need an amendment to their CARD plan.

If an amendment is required the following documentation must be included in the amendment and submitted to the Executive Office of Communities and Development for approval:

1. The extent, if any, the development/redevelopment will include the reuse of existing buildings for mixed use development. The plan should include a description of the community's need for housing, especially in the proposed CARD area, the nature and type of housing planned to meet those needs, and the various groups the housing is anticipated to serve.

2. If the CARD boundaries contain areas that are not now used for mixed use purposes, but which are intended to be converted or used for mixed use purposes in the future, the plan should include a statement outlining the zoning or land use changes that will be required and how this will be achieved.

3. A public hearing will be required before the amendment is approved. After a public hearing three findings must be made by the local governing body with respect to that portion of the project to be used for housing:

- That the project is located in areas needed to prevent the area in which it is located from becoming a substandard, decadent or blighted open area, as defined in section one of Chapter one hundred and twenty-one $A$.

- That the area will not by private enterprise alone and without either governmental subsidy or the exercise of governmental powers be developed or revitalized in such a manner as will prevent arrest or alleviate the spread of blight or decay.

- That the project is consistent with the sound needs of the municipality as a whole.

Contact MIFA, 723-4242 and/or EOCD, 727-7180 for additional information on how to prepare a CARD Plan amendment which includes a housing component. 


\author{
EXHIBIT II \\ MODEL RESOLUTION FOR LOCAL GOVERNING \\ BODY APPROVING A COMMERCIAL AREA \\ REVITALIZATION DISTRICT (CARD) PLAN
}

WHEREAS, in accordance with Chapters $40 D$ and 23B, Massachusetts General Laws, The Commonwealth of Massachusetts acting by and through the Secretary of Communities and Development may approve Commercial Area Revitalization Districts Plans (herein referred to as CARD Plans); and WHEREAS, such approval is a precondition for the use of various state financial incentives for commercial development that would be in the public interest of the citizens of (town/city); and

WHEREAS, the (development/redevelopment) of the (Title of District) CARD, the boundaries of which are described on

(insert page reference to the CARD Plan), would forward the community development objectives of the town (city) and would result in physical development (redevelopment) of said District and the creation of employment opportunities of a character consistent with that contemplated by the above cited statutes;

(Note: When a pre-existing document is being adopted as the CARD Plan, also include the following.

WHEREAS, the (title of pre-existing document) already has been prepared to guide the redevelopment of the commercial area, is still operational, and satisfies the statutory CARD Plan requirements.)

NOW, THEREFCRE BE IT RESOLVED BY THE (LOCAI GOVERNING BODY)

1. That the (title of district) (herein referred to as the CARD) Commercial Area Revitalization District described above is a predominantly commercial geographic area;

2. That implementation of the proposed CARD Plan will serve (to prevent) or (to avert and reverse) the decay of the area covered by the plan and will help deter the movement of commercial enterprises into previously noncommercial areas; and

3. That the (title of district) CARD Plan is hereby approved and that said Plan shall be submitted to the Secretary of Communities and Development for approval.

(Note: When a pre-existing planning document is being adopted as the CARD Plan, asubstitute the following for Item No. 3, above: 3. That the (title of pre-existing document) and Commercial Plan Status Report is hereby approved as the (title of district) CARD Plan and that said Plan shall be submitted to the Secretary of Communities and Development for approval.) 
751 CMR: EXECUTIVE OFFICE OF COMMUNITIES

AND DEVELOPMENT

8.06: continued

\author{
EXHIBIT III
}

MODEL CERTIFICATE OE RECORDING OFEICER

(To Accompany Resolution of Municipal Officers)

The undersigned hereby certifies, as follows:

1. That he is the duly qualified and acting (Town) (City) Clerk of the (TOWn) (City) of , herein called the "municipality" and the keeper of the recorders of the municipality, including the journal of proceedings of the (legal voters) (City Council))(Board of Selectmen), herein called the "Governing Body":

2. That the attached resolution is a true and correct copy of the resolution as finally adopted at a meeting of the Governing held on the day of, 19 , and duly recorded in his office;

3. That said meeting was duly convened and held in all respects in accordance with law; that to the extent required by law due and proper notice of such meeting was given; that a legal quorum was present throughout the meeting, and a legally sufficient number of members of the Governing Body voted in the proper manner and for the adoption of said resolution; and that all other requirements arid proceedings under law incident to the proper adoption or passage of said resolution, have been fulfilled, carried out and otherwise observed;

4. That if an impression of the seal has been affixed below, it constitutes the official seal of the Municipality and this certificate is hereby executed under such official seal. If no seal has been affixed below, the Municipality does not have and is not legally required to have an official seal;

5. That the undersigned is duly authorized to execute this certificate. 
751 CMR: EXECUTIVE OFEICE OF COMMUNITIES

AND DEVELOPMENT

8.06: continued

IN WITNESS WHEREOF, the undersigned has hereunto set his hand this day of , 19 .

(Signature of Recording Officer)

ATTEST

(Signature of Ailesting Officer)

(Title of Attesting Officer) 
751 CMR: EXECUTIVE OFFICE OF COMMUNITIES

AND DEVELOPMENT

8.06: continued

\title{
EXHIBIT IV
}

\author{
SAMPLE NOTICE OF PUBLIC HEARING
}

The City Council will hold a public hearing at (insert time) on (insert date) in the (insert location) to discuss the plans for creation of a (title of CARD District) Commercial Area Revitalization District (CARD). The suggested boundaries for the CARD are (insert description of boundaries or general location). A plan for the CARD's development will be presented at the hearing.

Section 12 of Chapter 40D of the General Laws (as amended by Sections 1 and 10 of St. 1978 Chapter 495) authorizes the use of tax-exempt industrial revenue bond financing for "commercial enterprises" provided that any such enterprise is located in a district for which a Commercial Area Revitalization Plan has been approved both by the City and by the Secretary of Communities and Development. A similar amendment to Chapter 23B makes approval of such a plan by the Secretary a precondition for the use of Urban Job Incentive Program Tax credits by commercial facilities. In the future, the State legislature may tie the availability of other incentives to CARD plan approvals.

\section{REGULATORY AUTHORITY}

Section 12 of Chapter 40D of the General Laws as amended (by Sections 1, Subsection (L) and Section 10 Subsection (K) of Statute 1978. Chapter 495 and Section 14 or Chapter 490 of the Acts of 1980), authorizes the use of industrial revenue bond financing for "commercial enterprises" provided that any such enterprise is located in a district for which a Commercial Area Revitalization Plan has been approved by the Secretary of Communities and Development. (Note: For the purposes of these rules and regulations, the plans in question will be referred to as Commercial Area Revitalization District Plans or CARDs.) A similar amendment to Chapter 23B makes approval of such a plan by the Secretary, a precondition for the use of Urban Job Incentive Program tax credits by commercial facilities. (Statute 1978, Chapter 499, Section $52,3,5$ ). 


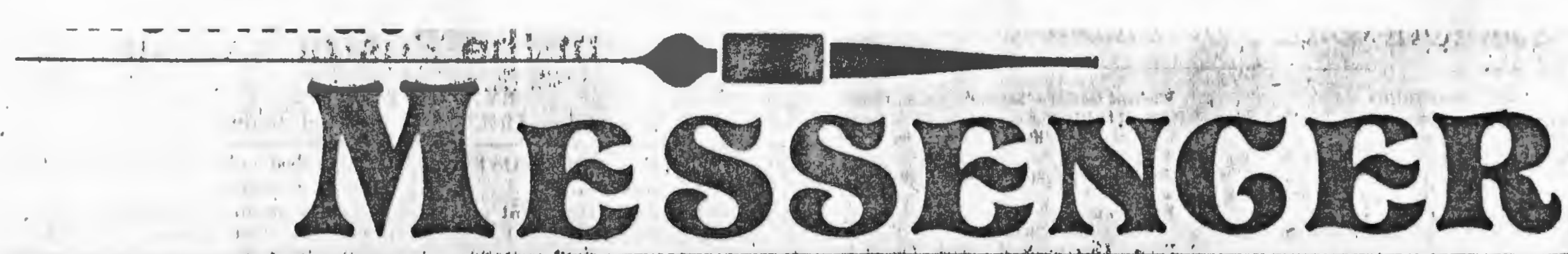

Serving Merrimac, Groveland, West Newbury \& Amesbury

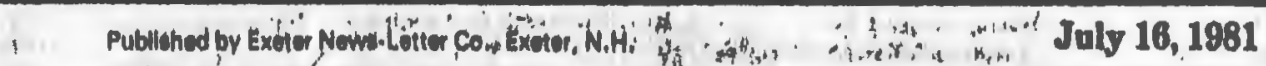

\section{Revitalization}

BY NONIE SARASIN

MERRIMAC - Merrimac Square has been choseh for a revitalization tudy:

Diane Flint chose the project for her master's thesis.' On its completion, the study will be presented to selectmen for
use by the town - all at no cost to the taxpayer.

in $(2$ thens?

Diane chbse Merrimac because, the said, she was "impressed "rith" the " architectural quality of the center" and its "sense of place in the human scalo."."

"People can be comfortablè "there," she said, "d quality lacking in many center areas."

the Bostion area,

Diane, who is from the Bostion area, looked at several communities belore she saw Merrimac, she saidi

"I saw potential in my' firet viait to Merrimac Square,"' Diace enthused. She was particularly impresed with the town hall building, which "speaks character and history," ind faj strong

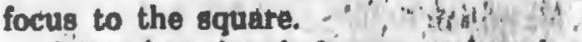
- Diane has already begun, work on her projecti She has met with the Merrimack Valley |Planning Commission and has been sranted use of their facilities. She has talked with Selectman Chairman Nancy MacGregor and Highway Supt. Spike Noone.

\section{4 , Interviews}

$\therefore$ She.will, in the course of the study, interview merchants and survey reaidents to bbtain their thoughts on their town center.

Diand holds a bachelor's degree from the University of Massachusetts in Amhersit where she majored in environmental design in the School of

Landscape Architecture and Regional Planning.

She worked in her field for awhile as assistant to the Planning Board in Durham, N.H., and in administrating a Community Dovelopment Block Grant prógram in Dover, N.H., - before returning fulltime as a graduate student at the University of Rhode Island. She is also employed part-time in the Planning Department "at Needham. She wants to be community planner.
49

inderth study for square

Her primary interest is historte preservation and downtown revitalization.

She feels Merrimac Square' gived her the exact opportunity to utlize her oldill. in line with her interest.

Comprehensive study

The comprehensive study will include an invientory of buildings, a look at land, use patterns, an examination of statiatics, review of conditions, look at retail sales data, an opinion of the ecohomics how and potentially and an assessment of existing problems.

It will.also contain proposals for an overall plan to enhance and improve the downtown area of Merrimac - ouch as; setting $a_{1}$ greenway - all tied in with. economic recommendations and sugges. tions for" implementation. Maps and sketches will be included as well.

In addition the study will encompass all the requirements for eligibility for inclusiot under the Massachusetts Commetclal Are' Revitalization District

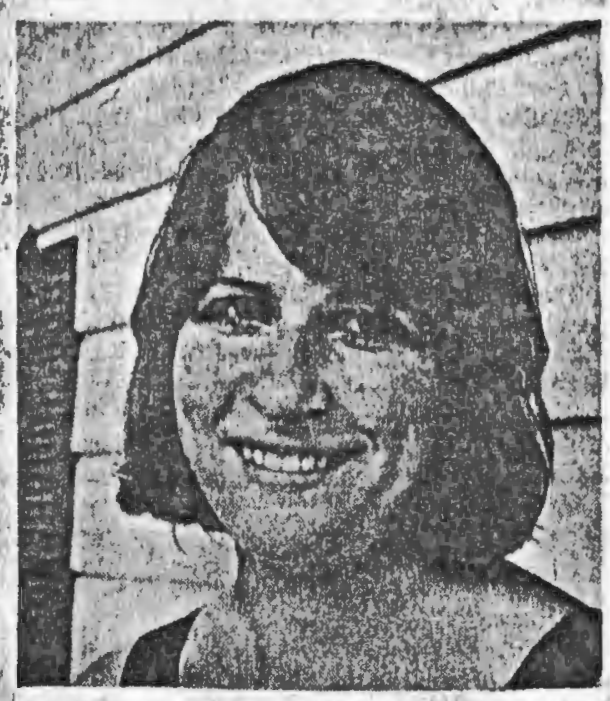

Diane Flint

(Pam Bayko)

(CARD) plan. Under the plan businesses? can obtain low interest financing through tax exernpt industrial revenue bonds.

Diane has had experience with the CARD program through her work in Needham.

Diane espeto to complete' the revitalization study by summer's end At that time she will present the study to selectmen', and it will be available for the town to use if it so desires - al valuable asset - a gift'from Diane Flint. 